\title{
HET OUD SPAANSCH KOLONIAAL STELSEL ZOOALS DIT IS NEDERGELEGD IN DE „LEYES DE INDIAS”.
}

LOOR

MR. J. H. ABENDANON.

\section{Inleiding.}

De algemeene benaming van het Spaansch territoir buiten Europa was aanvankelijk "Las Indias». Deze gold ook voor die gedeelten, verreweg de meest uitgebreide, welke zich in het werelddeel Amerika bevonden, en dit voor een groot deel omvatten.

Later kwam in gebruik de term: "Las provincias de U1tramar» (de overzeesche provincies), welke ook voorkomt in titel XIII der nog geldende Grondwet (constitución polí. tica) van 10 Juni 1876.

Thans heeft de uitdrukking "Las Indias» alleen historische beteekenis. Toch vindt men in artikel 21 der Grondwet, waar genoemd worden de autoriteiten, die ambtshalve leden zijn van den Senaat, naast de Aartsbisschoppen van het moederland, melding gemaakt van "E1 Patriarca de las Indias», de hoogste prelaat der koloniën.

Te Sevilla wordt ook nog het oud koloniaal archief aangeduid als "Archivo de Indias».

In overeenstemming met den gebiedsnaam werd de inheemsche bevolking van het vroegere buiten-Europeesche gebied aangeduid als "Indios».

Het Departement met de zorg voor de koloniale aangelegenheden belast heette "Ministerio de Ultramar». Het verving op 17 April 1812 met den "Consejo (Raad) de Ultramar» den Koninklijken Raad van lndië ("Consejo Real de las Indias»), welk college sedert 1542 , dus gedurende 270 jaren, het groote middelpunt was van de overzeesche belangen van 
Spanje. Voor handel en scheepvaart werd deze Raad bijgestaan door de "Casa de Contratación", te Sevilla gevestigd evenals de daaraan verbonden instellingen, die nader in het betrokken hoofdstuk zullen worden vermeld. ${ }^{1}$

$\mathrm{Na}$ het laatste koloniaal verlies dat Spanje leed als gevolg van den oorlog met de Vereenigde Staten van Noord-Amerika, werd voormelde Ministerio de Ultramar opgeheven (bij Kon. besluit van 25 April 1899). Sedert worden de belangen van het zeer klein geworden koloniaal gebied, dat zich tot Afrika bepaalt ${ }^{2}$, behartigd door eene afzonderlijke afdeeling van het Departement van Buitenlandsche Zaken ( Ministerio de Estadoy).

De wettelijke bepalingen waardoor de Spaansche Vorsten hun gezag in de overzeesche gewesten deden gelden, waren zeer talrijk. $Z \mathrm{ij}$ werden voor de betere raadpleging van tijd tot tijd bijeengebracht in Verzamelingen.

In 1680 gelastte Karel II $(1665-1700)$ de hernieuwde bijeenbrenging ("recopilación»), kortheidshalve aangeduid als "Leyes (wetten) de Indias», ten einde voor iedereen tot leiddraad te dienen bij de op menig gebied bestaande onzekerheid. Tot betere bereiking van dit doel werden de voorschriften over eenzelfde onderwerp bijeengevoegd, waardoor eene codificatie verkregen werd.

De eerste uitgave is van 1681 in vier $4^{\circ}$ deelen; de tweede van 1756.

In 1841 verscheen te Madrid een vijfde ${ }^{3}$ uitgave in vier $4^{\circ}$ deelen onder toezicht van de Kamer voor koloniale zaken (Sala de Indias) van het opperrechterlijk college (Tribunal Supremo de Justicia) onder den titel «Recopilación de leyes de los reinos de las Indias mandadas imprimir y publicar por la Magestad Católica del Rey Don Carlos IIs, (Verzameling van wetten der koloniale rijken gedrukt en uitgegeven op last van $\mathrm{Zijne}$ Katholieke Majesteit

1 Zie hoofdstukken XVIII, XIX, XX en XXI.

- Fernando Poo en een deel der kust van Guinea, alsmede het NoordWestelijk gedeelte van Marokko.

De Canarısche Eilanden vormen samen eene provincie van Spanje, en worden niet als koloniaal gebied beschouwd.

3 De derde en vierde uitgaven ken ik niet. 
Koning Karel II). Aan het slot volgt eene alphabetische lijst van onderwerpen met korte samenvatting van den inhoud.

In 1889 en 1890 verscheen met machtiging van de Regeering te Madrid bij Pedro Nuñez eene nieuwe uitgave onder leiding van don Miguel de la Guardia, hoogleeraar te Valencia en directeur-generaal van de afdeeling rechtszaken (Gracia y Justicia) aan het voormalig ministerie van koloniën (ministerio de U 1 tramar) in 13 deelen $\left(8^{\circ}\right)$.

Het werk is verdeeld in negen boeken; deze weder in titels en artikelen, welke laatste ley (wet) heeten.

Boven elk artikel zijn vermeld: de Vorst door wien, de plaats waar en de dagteekening waarop de afkondiging geschiedde met eene korte samenvatting van den inhoud. Aan het slot vindt men eene alphabetische lijst van onderwerpen.

De volgorde en de samenvoeging der onderwerpen zijn weleens anders dan de lezer zou verwachten, terwijl dikwijls herhalingen in een ander verband voorkomen, waardoor gevaar voor verwarring ontstaat en de raadpleging niet gemakkelijk is. Antwoord op vragen, die zich bij de lezing voordoen, is niet altijd te vinden. Uit den aard der zaak wordt veel als bekend verondersteld.

De oudste voorschriften in de Leyes de Indias voorkomende zijn van het Katholiek Koningspaar, "los Reyes Católicos», Isabel la Católica en Fernando, die van 1469 tot 1504, het sterfjaar der eerste, vereenigd waren.

De nieuwste voorschriften zijn uit de tweede helft der XVIJ ${ }^{\mathrm{e}}$ eeuw.

De in lateren tijd afgekondigde bepalingen zijn niet in de Leyes de Indias opgenomen. Men heeft blijkbaar de codificatie van Karel II als een historisch monument van wetgeving willen bewaren.

Hoe merkwaardig de nieuwere koloniale wetgeving ook is, zij valt in het algemeen buiten het kader van dit stuk. Slechts hier en daar zal hiervan melding worden gemaakt.

Voor hen, die van de toestanden in de Spaansche koloniën eene meer algemeene studie wenschen te maken, moge naast de verhandelingen van de las Casas, Antonio de Ulloa y Jorge Juan, Gomara, Depons enz., die men aangehaald vindt bij de schrijvers, die de koloniale geschiedenis hebben behandeld, onder vele andere worden verwezen naar de hieronder 
volgende in Nederland minder bekende werken, die ik onlangs, in Spanje zijnde, in handen heb gehad:

Historia de las Indias de Nueva España y islas de Tierra Firme (Geschiedenis van het koloniaal gebied in Mexico en de bij het vasteland behoorende eilanden) door Fray Diego Duran, geschreven in de tweede helft der $\mathrm{XVI}^{\mathrm{e}}$ eeuw, doch eerst in 1867-1880 uitgegeven door José F. Ramirez in 3 deelen bij Andrade y Escalante te Mexico. Het bevat vooral de geschiedenis van Mexico vóór de komst en tijdens het eerste verblijf der Spanjaarden.

Lopez de Velasco. Geografia y descripción universal de las Indias (1511-1574), uitgegeven door Justo Zaragoza.

Bijzonder belangrijk is eene verzameling brieven in 1877 te Madrid bij Hernandez uitgegeven van Regeeringswege door eene commissie onder voorzitterschap van Justo Zaragoza, destijds Directeur-Generaal van het Openbaar Onderwijs. Het op zeer groot formaat gedrukt werk "Cartas de Indias" (koloniale brieven) eindigt met vier kaarten, een lijst van facsimile's, van vreemde woorden en van biographische aanteekeningen.

Voor de latere koloniale geschiedenis raadplege men het werk van Miguel Blanco Herrero, Política de España en Ultramar (Madrid bij A. de San Martin 1888).

Met het oog op hetgeen ten aanzien van de indeeling der onderwerpen op bl. 75 is vermeld, heb ik niet altijd de Leyes de Indias op den voet kunnen volgen. Voorop stellende dat bevordering van den godsdienst aanvankelijk een der voornaamste drijfveeren is geweest, lag het voor de hand in de eerste hoofdstukken te behandelen de geestelijkheid en met deze samenhangende instellingen, waartoe ook behooren de universiteiten, om hierop te doen volgen den geneeskundigen dienst wegens het - zooals blijken zal - nauw verband met de Faculteit der Geneeskunde, en de uitgave en den invoer van boeken.

Overigens is mijn gedachtengang geweest: De ontdekkingsreizen; voorschriften omtrent de scheepvaart en de beschermingskosten daarop vallende; vestigingen van Spanjaarden en andere van buiten komende personen. Dan de inboorlingenpolitiek, waarvan de eerste uiting is de verdeeling van grond en de stichting van de zoogenaamde encomiendas, waarmede ten deele samenhangen de persoonlijke diensten en de mijnarbeid, 
Hierna het Bestuur in het moederland: Koning, Raad van Indië, instellingen in het belang van handel en scheepvaart op de overzeesche gewesten, tevens dienende als organen van toezicht daarop.

Vervolgens de wetgeving en het bestuur in de overzeesche gewesten, alsmede de rechtspraak, de gevangenissen, de politie en het notariaat, het mijnwezen, de parelvisscherij, het fabriekswezen en de inheemsche gemeenschaps-instellingen.

Eindelijk de latere beperkingen op het gebied van handel en scheepvaart; de rekenplichtigheid en de belastingen.

Ik hoop dat men hierbij het variis modis bene fit in het oog zal willen houden. Ook wat betreft de verdeeling van sommige hoofdstukken in paragrafen, ter vergemakkelijking van de raadpleging.

Hoofdzakelijk hebben de "Leyes de Indias» alleen belang uit een historisch oogpunt, maar er valt toch ook veel uit te leeren. Naast de dwalingen, die het gevolg waren van zeer eenzijdige opvattingen eigen aan de $\mathrm{XVI}^{\mathrm{e}}$ en $\mathrm{XVII}^{\mathrm{e}}$ eeuw, en die zelfs in lateren tijd zich deden gelden, ook in de overzeesche gewesten van andere landen dan Spanje, leert men nuttige instellingen kennen, die, vooral met het oog op den tijd waarin zij tot stand kwamen, alle aandacht verdienen. Hetzelfde geldt van sommige denkbeelden, die een lichtgevenden achtergrond vormen bij andere voor de ontwikkeling der menschheid te betreuren gebeurtenissen.

$\mathrm{Bij}$ het lezen van de strenge bepalingen tot bescherming van de inboorlingen, vraagt men zich onwillekeurig af hoe deze te rijmen zijn met de groote wreedheden die volgens de geschiedschrijvers voorkwamen. Dit schijnbare raadsel wordt opgelost, wanneer men let op de jaartallen waarin bedoelde bepalingen tot stand kwamen. $Z_{\mathrm{ij}}$ waren n.l. juist het uitvloeisel van de onmeedoogende handelingen welke den aanvang der overzeesche heerschappij kenmerkten, m. a. w. zij hadden de strekking om dergelijke handelingen met kracht te bestrijden.

De omstandigheid, dat herhaling van voormelde bepalingen noodig bleek, wijst er helaas op, dat zij niet dadelijk doel troffen, doch is tevens een bewijs dat de aandacht van den wetgever in zeer bijzondere mate op de belangen der inheemsche bevolking gevestigd bleef. 
Dat de tijdgeest zich, vóór alles ten aanzien van den godsdienst, deed gelden, ligt voor de hand.

Het uitgangspunt der Spaansche Vorsten was zeer uitdrukkelijk de heilige Katholieke geloofsleer ( «la santa fé católica»), welke hen met dankbaarheid deed gedenken de groote verantwoordelijkheid hun door het Opperwezen opgelegd en de dure verplichtingen hieruit voortvloeiende. In den aanvang van het eerste Boek leest men: "Dios nuestro Señor por su infinita misericordia y bondad se ha servido de darnos sin merecimientos nuestros tan grande parte en el señorio de este mundo, que demás de juntar en nuestra Real persona, muchos y grandes Reinos, que nuestros gloriosos progeniteros tuvieron, siendo cada uno por si poderoso Rey y Señor, ha dilatado nuestra Real Corona en grandes provincias, y tierras por Nos descubiertas, y señoreadas hacia las partes del mediodia y poniente de estos nuestros Reinos». Dit beteekent: "God onze Heer heeft in zijne oneindige goedertierenheid en goedheid besloten ons onverdiend een zoo groot deel toe te kennen in de heerschappij van deze wereld, dat $\mathrm{Hij}$ niet alleen in onze Koninklijke persoon vele en groote Rijken vereenigd heeft, die onze roemrijke voorouders bezaten, ieder hunner op zich zelf reeds een machtige koning en gebieder, maar dat $\mathrm{Hij}$ ook onze Koninklijke Kroon heeft uitgestrekt tot groote provincies en gebieden door ons ontdekt, en inbezitgenomen in de zuidelijke en westelijke deelen van deze onze Rijken ${ }^{1}$.

Hierop volgt dan: «En aangezien het onze wil is, en wij dit hebben beloofd en bezworen, dat deze landen voor altijd verbonden zullen blijven tot grootere kracht en langer voortduren, verbieden wij de vervreemding daarvan. En gelasten wij, dat zij nimmer afgescheiden mogen worden van onze Koninklijke Kroon van Kastilië, noch geheel noch ten deele, noch zelfs enkele steden of andere vestigingen, om geen enkele reden en ten behoeve van niemand. Wat ook in deze richting te eeniger tijd moge gedaan worden, zal van geene waarde zijn».

Deze verklaring gaat gepaard met het dringend verzoek aan alle inboorlingen om mede te werken tot hun heil door met

\footnotetext{
1 Schenking door den Heiligen Apostolischen Stoel werd hierbij als een der middelen van verkrijging erkend.
} 
ontvankelijk gemoed (benignamente) te luisteren naar de woorden van de tot hen gezonden predikers.

In het testament van Isabel "la Católica» komt over de goede behandeling van de inboorlingen en hun overgang tot de heilige Katholieke leer een uitvoerige in vriendelijke bewoordingen gestelde aanbeveling voor aan haar gemaal en aan haar dochter en schoonzoon, welke ter kennis werd gebracht van de onderkoningen, hooge geestelijken en andere hoogwaardigheidsbekleeders.

Ook Karel I (V) ${ }^{1}$ en de later op den troon komende vorsten dringen tot in bijzonderheden aan op deze goede behandeling en geven ter zake telkens hernieuwde voorschriften, die er op duiden dat vele misbruiken waren ingeslopen. Hoofdzaak is hierbij het verbod van gedwongen leveringen en van werkverrichting zonder goede betaling. Ook tegen betaling mochten sommige handelingen niet geschieden, bijv. het vervoer van Spanjaarden, onverschillig hun stand of betrekking, in hangmatten en draagstoelen, behoudens het geval van duidelijk gebleken ziekte. De inboorlingen hadden het recht hun beklag in te dienen bij de bevoegde autoriteiten. Bijzondere bescherming genoten zij tegenover negers, die met 100 zweepslagen gestraft werden voor elk vergrijp tegen inboorlingen. In 1593 wordt zelfs bepaald, dat Spanjaarden, die zich aan inboorlingen vergrijpen, strenger gestraft moeten worden dan wanneer zij dezelfde handelingen tegen landgenooten begaan.

Karel II komt evenals zijn voorganger Filips IV, met medewerking van den Raad van Indië, met kracht op tegen de misbruiken tegenover inboorlingen en schrijft eigenhandig op het desbetreffend voor de landvoogden bestemde stuk: «Quiero que me déis satisfacción á mi y al mundo del modo de tratar esos mis vasallos, y de no hacerlo, con que en respuesta de esta carta, vea yo ejecutados ejemplares castigos en los que hubieren excedido en esta parte, me daré por deservido, y aseguráos que aunque no lo remediéis, lo tengo de remediar, y mandaros hacer gran cargo de las mas leves omisiones en esto, por ser contra Dios $y$ contra mi, y en total ruina y destrucción de estos Reinos, cuyos naturales estimo y quiero

1 Als Spaansch Koning was hij de eerste Karel (Carlos), ofschoon ook in Spanje deze Vorst als de vijfde (Carlos Quinto) wordt aangeduid. 
que sean tratados como lo merecen, vasallos que tanto sirven á la monarquía y tanto la han engrandecido é ilustrado.»d.w. z. "Ik wil dat gijlieden mij en de wereld bevredigt in de wijze waarop gij mijne onderdanen daar behandelt. Doet gij dit niet, zelfs niet naar aanleiding van dezen brief, dan moet ik voorbeeldige straffen toegepast zien op hen die te kort geschoten zijn. Ik zal zeer ontstemd zijn, en verzeker ulieden, dat indien gij geen orde hierop stelt, ik het zal hebben te doen. De minste tekortkomingen in dit opzicht zal ik ulieden zwaar aanrekenen, omdat zij te beschouwen zijn als gericht tegen God en tegen mij, en tevens leiden tot algeheel nadeel en vernietiging van gindsche Rijken, welker inboorlingen ik lief heb en die ik behandeld wensch zooals zij verdienen. Want zij zijn onderdanen, die aan ons Koninkrijk groote diensten bewijzen, en veel hebben bijgedragen tot de grootheid en den luister daarvan.» Zie ook bl. 158.

De goede behandeling moest echter gepaard gaan met de bekendmaking van de Katholieke geloofsleer. De eerste wet hieromtrent is van 1526. $\mathrm{Zij}$ werd telkens herhaald, onder bijvoeging dat geen geweld gebruikt mocht worden. Wel echter waren bijzondere middelen aangegeven. Zoo bijv. het aanrichten van feesten met muziek en gezang, gepaard met prediking. Afgodsbeelden waren met beleid en zooveel mogelijk met overreding te verwijderen. Hetzelfde gold voor de bestrijding der heidensche instellingen. Predikers van den afgodendienst kregen eene plaats in een klooster om daar hunne dwaling te leeren inzien. De bijwoning der dagelijks op een bepaald uur voorgeschreven prediking was voor allen - ook voor Spanjaarden, bedienden en slaven - verplicht op straffe van geldboete. Het helpen bedienen van de mis was daarentegen vrij. Het werken op Zon- en feestdagen was verboden. De gedoopte inboorlingen mochten hun haar lang blijven dragen. Het afknippen van haar bij wijze van straf was niet toegelaten. De kennis der landstaal was voor priesters een onmisbaar vereischte om in de koloniën te mogen optreden. Tevens moest echter gestreefd worden naar verspreiding van het Spaansch onder de inboorlingen. ${ }^{1}$

1 Het ijveren voor het Christendom onder de inheemsche bevolking treedt ook in Ned. Indië, reeds kort na oprichting der Vereenigde Oost-Indische Compagnie, en later, aan den dag.

In de instructie voor den Gouverneur-Generaal en de Raden van Indië 
Tal van voorschriften zijn gewijd aan de oprichting en het onderhoud van kerken en kloosters - zoowel voor mannen als voor vrouwen - alsmede van gebouwen ten behoeve van zieken en weezen en van de broederschappen (cofradias), met aanduiding o.a. van de verdeeling der kosten tusschen den staat en de bevolking.

Voor de kloosters werd een onderlinge afstand van minstens 6 mijlen vereischt, ten einde onder de bevolking zooveel mogelijk nut te kunnen verspreiden.

De eerbied voor kerken en kloosters verhinderde niet den last om manschappen van leger en vloot, die zich daarin zouden willen verbergen, er uit te verwijderen.

\section{Geestelijkheid.}

De invloed der geestelijkheid vond een tegenwicht in het patronaat over de kerk en de kerkelijke instellingen, dat den Koning toekwam, hetzij door uitdrukkelijke toekenning van den Heiligen Stoel ${ }^{1}$, hetzij krachtens gewoonterecht. Dit patronaat

van 1617 leest men, dat zij noveral op de voortplanting van de Christelijke religie, opbouwing van goede scholen en andere zaken daartoe noodig, alle behoorlijke orde (zullen) stellen."

In 1635 wordt zelfs bepaald, dat aan ieder "Indiaens persoon" die zich liet doopen, van Compagnie's wege zouden worden geschonken twee Nederlandsche kroonen van 40 stuivers om "tot het aennemen der gereformeerde religie te animeeren, ende oock te toonen, hoe aengenaem ons is, dat ons Heydense en Moorse gemeente haere salicheyt door den eenigen Salichmaeker, de $\mathrm{H}^{\text {ro }}$ Christo mogen trachten te soecken."

In 1613 worden onder Van Diemen een reeks voorschriften afgekondigd om "de bekeeringe der Heydenen te vorderen", o. a. daartoe strekkende, dat "de praedicanten ende cranckbesoeckers haer (zich) benaerstigen, datse inde taele, welcke de Heydenen, waarmede ons de meeste conversatie is, verstaen, insonderheyt in het Portugees, Maleys ende Chinees gestilleert werden, om een yegelijcke natie nae haer begryp ende verstandt inde fondamenten van de Christelycke religie t' onderwysen ende het Woort Gods toe te deylen".

Tevens werd het noodig geacht ${ }_{n}$ dat de Inlantse Christenen ingescherpt werden, dat haer selven oock uyterlyck in haere habyten confirmeeren naer de maniere van de Nederlanders".

Later toen het aantal "Inlandsche Christenen" de oprichting van afzonderlijke kompagniën en zelfs van een bataillon mogelijk maakte, vindt men herhaaldelijk gewag gemaakt van verhooging van militaire inkomsten, en wel in 1790, 1795, 1796 en 1801. (Men zie Ned. Indisch Plakaatboek (1602-1811) door Mr. J. A. van der Chijs. I. 39 en 371, II. 55 en 56, XI. 234, XII. 62, 200, 569 en XIII. 331).

1 Nog bij het concordaat van 17 October 1851 werd het koninklijk patronaat Dl. 79 . 
bestond voor het geheele gebied buiten Europa ("todo el estado de las Indias») en strekte zich ook uit tot de waarde te hechten aan Pauselijke brieven en bevelen. Zelfs door Karel I (V) en Pilips II was bepaald, dat dergelijke stukken vooraf in handen moesten komen van den Raad van Indië te Sevilla (Consejo de Indias), ten einde na registratie aan het oordeel des Konings onderworpen te worden, die zoo noodig zich met Rome in betrekking stelde. Onder Filips IV werden opnieuw bepalingen in dezen zin gemaakt.

De goedkeuring der geestelijke benoemingen berustte bij den Koning, evenals de regeling van de rechten en verplichtingen der geestelijkheid. Zelfs de hooge geestelijkheid mocht zich niet naar de koloniën of vandaar naar het moederland begeven zonder Koninklijke machtiging. Geen enkele geestelijke mocht zich door verwanten doen vergezellen. Na 10 jaren verblijf in de koloniën hadden de geestelijken recht op tijdelijk verblijf in het moederland. De hooge geestelijkheid had echter de opdracht om hen zooveel mogelijk van hun recht te doen afzien.

Voor de oprichting van elke kerk of van eenig ander heilig gebouw was de toestemming van den Koning noodig.

Reeds in 1588 werd toegestaan om personen van gemengd bloed, mits in wettig huwelijk geboren, en daartoe geschikt geacht, als geestelijken te ordenen en als nonnen in kloosters toe te laten. Later schijnen ook inboorlingen priesters te hebben kunnen worden, want in een Kon. besluit van 1837 werd bepaald, dat dit slechts bij uitzondering het geval zou zijn.

Omstreeks denzelfden tijd komt de last aan de prelaten om lagere geestelijken te bestraffen, die zich tegenover de bevolking misdragen, o.a. door verkrachting van vrouwen en meisjes, door gedwongen heffingen of berooving van bezittingen bij gelegenheid van doopen, huwelijken, begrafenissen, en de regeling van nalatenschappen, door het opleggen van gedwongen werk, het spel, enz.

In 1559 beval Filips II de geestelijke rechtspraak binnen de aangewezen grenzen te houden ${ }^{1}$. Meermalen herhaald, voerde

(Patronazgo Real) bevestigd. In een Koninklijk besluit (Real Cédula) van 23 Maart 1872 zijn te dezer zake voorschriften aan de geestelijkheid verstrekt (de la Guardia II, bl. 154).

$1 \mathrm{Nog}$ in 1868 (wet van 6 Dec.) werd de uitoefening der kerkelijke rechtspraak in de destijds bestaande Spaansche koloniën erkend, zoowel in burgerlijke als in strafzaken. Wat de eerste betreft o. a. de uitspraak over huwelijksnietigheid en de scheiding van tafel en bed (ar. 104 Código Civil). 
Filips IV in 1630 zelfs als overweging voor een hernieuwd gebod aan, dat de geestelijken zich het opleggen van straffen aanmatigden in aangelegenheden geheel buiten kerk en godsdienst staande. Vroeger reeds, in 1590, was den geestelijken verboden zich met regeeringszaken in te laten, evenals het aan leeken verboden was zich met kerkelijke aangelegenheden te bemoeien. Toch kregen sommige autoriteiten in 1619 de bevoegdheid toezicht te houden op het gedrag van lagere geestelijken en zoo noodig bestraffing te provoceeren, hetzij door de geestelijke rechtbanken, hetzij door verwijdering uit de koloniën, zooals reeds in 1568 door Filips II was gelast, ook ten aanzien van personen, die, om zich aan eene opgelegde straf te onttrekken, priesters werden.

De geestelijken mochten geen burgerlijke ambten of bedieningen uitoefenen, noch op eenigerlei wijze handel drijven, of deelnemen aan mijnbouw, parelvisscherij, enz. Over hunne goederen mochten zij bij testament beschikken. Nalatenschappen van zonder testament overledenen kwamen aan de legitimarissen.

De verplichting tot betaling van belasting rustte ook op de geestelijken. Hielpen zachte aanmaningen van de prelaten niet, dan was de gewone rechter bevoegd zijn gezag te doen gelden.

In 1531, 1568, 1595 en 1634 werd het uiten van ergernis gevende woorden ( $\mathrm{palab}$ ras escandalosas) tegen het Gouvernement, de ministers en de rechters van den kansel verboden op straffe van opzending naar het moederland. Meenden de geestelijken opmerkingen te moeten maken, dan behoorde dit op gepaste wijze privatim te gebeuren.

Aan oproepingen van de koloniale landvoogden en den rechter hadden de geestelijken gevolg te geven. Deze oproepingen behoorden echter met groot beleid te geschieden.

De geestelijken, die van Regeeringswege met de prediking en kerstening van een bepaalde streek belast waren, mochten niet dan om dringende redenen van de prelaten een anderen werkkring krijgen. $\mathrm{Zij}$ waren ook belast met het houden van registers van geboorte, doop en overlijden, waaruit sedert 1606 jaarlijks een uittreksel aan den landvoogd werd gezonden.

Aan de geestelijken was opgedragen om onderling broederschap en eensgezindheid te betrachten, en opkomende oneenigheden onder elkander of met inboorlingen met takt bij te leggen. 
Dit betrof ook de klooster- en ordebroeders ${ }^{1}$. Ten aanzien van dezen gold in 1558 eene bijzondere bepaling, welke ook nu nog de aandacht verdient van de autoriteiten in koloniën, waar het Christendom zoowel van Katholieke als van Protestantsche zijde gepredikt wordt. Waar zich n.l. in eenig district eene bepaalde orde gevestigd had, mocht geen andere worden toegelaten, noch tot prediking van hare leerstellingen, noch tot oprichting van kloosters. In 1594 kwam hetzelfde beginsel meer uitvoerig tot uiting voor de Filipijnen, waar het ook in onzen tijd toepassing vond.

Jaarlijks hadden overeenkomstig Pauselijk voorschrift conciliën plaats, waaraan de landvoogden hadden deel te nemen, met verplichting voor de richtige uitvoering van genomen besluiten te doen zorgen.

Krachtens Pauselijke beschikking kwamen de ten behoeve der Kerk opgebrachte tienden aan den Koning d.i. aan de schatkist. $\mathrm{Zij}$ werden in natura geheven van veldgewassen, van vrucht- en andere boomen, van rund-, pluim- en trekvee, van melk, boter en kaas, suiker enz. Ook van hetgeen dẹ Spaansche landontginners van hunne opgezetenen inden, hadden $\mathrm{zij} 1 / 10$ aan den Koning op te brengen.

In verband hiermede zij vermeld het door Paus Urbanus VIII aan de schatkist afgestane recht om van het maandelijksch inkomen van allen, die eenig kerkelijk ambt vervulden, zeker bedrag te heffen (mesada e clesiástica) ${ }^{2}$. Aanvankelijk stelde de Paus dit bedrag om de vijf jaren vast. Karel III en Karel IV verkregen de vaststelling voor hun leven. De heffing begon eerst vier maanden na de aanvaarding van het ambt.

Krachtens een Kon. besluit van 26 Jan. 1777 waren alleen de hoogste geestelijken de mesada aan de schatkist verschuldigd, en wel $18 \%$ van hun inkomen.

Kerkelijke rechten werden ook geheven van de begraafplaatsen. ${ }^{3}$

Het belangrijkst uit een historisch oogpunt zijn, in verband

1 Het op bl. 82 bedoelde Kon. besluit van 1837 verbood ook het opnemen van inboorlingen in de geestelijke orden, behoudens hooge uitzondering. Vóór dien tijd schijnt het dus geoorloofd te zijn geweest.

2 Mesada (van mes = maand) $=$ maandelijksch inkomen.

s In de Filipijnen betaalden de inboorlingen in de laatste jaren der Spaansche heerschappij ten behoeve van den eeredienst $\frac{1}{2}$ reaal van hunne onroerende goederen ("diexmo"). 
met de geestelijkheid, de titels XIX tot XXIV van het eerste boek, achtereenvolgens gewijd aan de Inquisitie (de rechtbanken van het heilige officium), aan de "Santa Cruzada», aan de Limosnas, aan de universiteiten en bijzondere "Colegios» en Seminaria, en ten slotte aan het drukken en invoeren van boeken.

\section{Inquisitie.}

\section{(Santo Oficio de la Inquisición).}

De Inquisitie (Santo Oficio de la Inquisición) ${ }^{1}$ werd voor de overzeesche gewesten in 1569 ingesteld door Filips II met eene uitvoerige beschouwing over het doel: de wenschelijkheid nl. om door alle middelen te zorgen voor de verbreiding en verheffing van het heilige geloof, alsmede voor de zuiverheid en de volmaaktheid daarvan door het vrij te houden van dwaalbegrippen (herejías). ${ }^{2}$ De Koning gelastte algemeene eerbiediging en machtsverzekering, en bepaalde met het oog hierop, dat alle rechtszaken die de Inquisitie zich aantrekt, ophouden te behooren tot de bevoegdheid der rechterlijke en administratieve autoriteiten. Deze laatsten namen voortaan een lageren rang in dan de inquisiteurs, aan wie verschillende ambtelijke voorrechten werden toegekend, met bepaling dat zij de bijzondere bescherming van den Koning zouden genieten. Waar eene rechtbank der Inquisitie werd opgericht, moesten de leden daarvan onder geschutvuur door alle autoriteiten met buitengewone eerbewijzen worden ontvangen ( con $\mathrm{mas} d \mathrm{e}-$ mostración de la ordinaria»). Het oudste lid ging ter rechterzijde van den bisschop, het jongste op dezelfde wijze naast den landvoogd. In de kerk werd een Te Deum gezongen en

1 De instelling der rechtsmacht tot onderzoek en bestraffing van vergrijpen tegen het Katholieke geloof, m. a. w. de Inquisitie, bestaat sedert de $13^{\circ}$ eeuw (19 Maart 1227) op last van Paus Gregorius IX.

De eerste geestelijke rechtbank in Spanje kwam op 1 Augustus 1233 te Lerida tot stand. Te Sevilla eerst in 1480 op bevel van de Reyes Católicos en in Aragon in 1485. De eerste Inquisiteur Generaal Fray Tomás de Torquemada kondigde op 29 October 1480 eenige voorschriften af.

Krachtens het decreet van Cadix werd de Inquisitie op 22 Februari 1813 in geheel Spanje afgeschaft, op voorstel van een der door de Canarische eilanden afgevaardigde priesters. Bij besluit van Fernando VII op 21 Juli 1814 in gewijzigden vorm opnieuw ingevoerd, kwam er in 1820 wederom een einde aan. Eerst op 15 Juli 1834 had echter de definitieve afschaffing plaats. De bezittingen der Inquisitie werden toen gebezigd tot afdoening der Staatsschuld.

2 Men vergelijke hierbij XV § 10 . 
een misa solemne uitgevoerd, waarbij de inquisiteurs op een tapijt fluweelen stoelen met kussens innamen. $\mathrm{Na}$ afloop werden zij in optocht naar huis begeleid. Zoo ook eenige dagen later nadat het geloofsedict was afgekondigd.

Dat de inquisiteurs weleens van hunne macht misbruik maakten, valt af te leiden uit verbodsbepalingen van 1601 en 1610 om de post aan te houden, om het vertrek van schepen of van passagiers van hunne toestemming afhankelijk te maken, om personen die wegens geloofszaken terecht moesten staan, te onttrekken aan den wereldlijken rechter in reeds aangevangen misdrijfzaken, om zich in te laten met bestuurszaken buiten hunne bevoegdheid ("que no tocan á su ministerio»). In 1601 en 1633 werden op voorstel van eene commissie, bestaande uit twee inquisiteurs en twee wereldlijke rechters, een aantal voorschriften afgekondigd om geschillen van bevoegdheid te voorkomen.

Het inkomen der inquisiteurs bestond o. a. uit een deel der door hen opgelegde geldstraffen. $\mathrm{Zij}$ vermochten bovendien galei-, lijfen doodstraf uit te spreken.

\section{College voor de aflaatbrieven.}

\section{(Santa Cruzada).}

"Santa Cruzada) was een College door den Paus belast met de zorg voor de aflaatbrieven en het beheer der gelden welke deze opbrachten krachtens vastgestelde tarieven. Het College had ook zekere rechtsmacht, o. a. ten aanzien van de gelden aan hooge geestelijken als zoodanig opgebracht, die bij hun overlijden aan de kerk en aan de armen moesten komen. De Santa Cruzada mocht zich echter niet inlaten met nalatenschappen van zonder testament overledenen, noch met goederen waarvan de eigenaar onbekend is. In 1851 werd de zorg voor de Santa Cruzada en alles wat hiermede samenhing, opgedragen aan den Aartsbisschop van Toledo. In $1852 \mathrm{kwam}$ ook aan de afzonderlijke rechtsmacht een einde, met opdracht daarvan aan den gewonen rechter. In $1855 \mathrm{kwam}$ wederom wijziging door de opdracht van de algemeene leiding aan eene Commissie, ressorteerende onder het Ministerie van Justitie (Gracia y Justicia), doch ondergeschikt aan voornoemden Aartsbisschop. Vobr 1851 werd de instelling in het moederland genoemd: "espolios y vacantes, en had dan betrekking op de opengevallen nalatenschappen van prelaten. 
In het algemeen is de geestelijke rechtspraak sedert 1833 sterk verminderd. Krachtens de wet van 6 December 1868 werd zij beperkt tot de zuiver kerkelijke zaken, aangeduid als "ca us as sacramentales y beneficiales» en de kerkelijke delicten.

\section{Giften ten behoeve van de kerk.}

\section{(Limosnas).}

Aangaande de "limosnas» (giften ten behoeve der kerk) is het voldoende te vermelden, dat deze niet mochten worden geïnd zonder uitdrukkelijk verlof van den Raad van Indië.

\section{Universiteiten en andere onderwijsinstellingen.}

Merkwaardig is de oprichting van universiteiten, reeds in 1551, te Lima (Peru) en te Mexico (Nueva España) met het doel om den godsdienst te bevorderen en tevens gelegenheid te geven tot het verkrijgen van ontwikkeling in alle richtingen. De rectoren moesten beurtelings een geestelijk en een wereldlijk geleerde zijn. $\mathrm{Zij}$ mochten zich door twee negerlakeien met degens doen volgen. Nader werden ook elders, met name in Santiago (Chili), in Santo Domingo en in de Filipijnen met Pauselijke toestemming hooger-onderwijs-inrichtingen tot stand gebracht.

$\mathrm{Zij}$, die in eenige faculteit een graad verkregen (licenciados, doctores en maestros), hadden uitdrukkelijk de geloofsbelijdenis der Katholieke Kerk af te leggen, en tevens trouw en gehoorzaamheid te zweren aan den onderkoning, de rechterlijke autoriteiten en den rector. De graden werden in de hoofdkerk verleend.

Als faculteiten worden vermeld : theologie, kanoniek en wereldlijk recht, geneeskunde, letteren en philosophie. Reeds in 1580 vindt men bepaald, dat er leerstoelen moeten zijn voor de talen der inboorlingen (Indios). In 1627 wordt als beginsel uitgesproken, dat de studie dezer talen in het bijzonder bij Jezuieten behoort te berusten. Dit voorschrift trekt vooral daarom de aandacht, omdat in 1576 aan de Jezuieten-colleges het recht ontzegd werd om academische graden toe te kennen.

De hoogleeraar-benoemingen geschiedden door eene commissie, voorgezeten door den aartsbisschop en verder samengesteld uit aangewezen kerkelijke en wereldlijke autoriteiten, o.a. den rector en den deken der betrokken faculteit. De in aanmerking komende personen mochten proeven van hunne bekwaamheid afleggen, een 
soort vergelijkend examen dus. Ook nu nog komt dergelijke gewoonte in Spanje voor onder den naam van "por oposición».

Voor de opleiding van geestelijken dienden vooral de "colegios seminarios» overeenkomstig het Heilige Concilie van Trente. In de stad Mexico bestond sedert 1557 dergelijke opleidingschool voor behoeftige kinderen van gemengd bloed ("mestizos»).

In Manila (Filipijnen) kwam in 1644 eene universiteit tot stand krachtens bul van Paus Innocentius X (van 20 November), die hiermede voldeed aan een verzoek van Filips IV. De universiteit ontstond geleidelijk uit een "Colegi os, sedert 20 April 1619 gewijd aan den heiligen Rosario, welks beteekenis uit wetenschappelijk oogpunt steeds grooter was geworden. Op 16 Maart 1778 werden de leerstoelen belangrijk uitgebreid en in overeenstemming gebracht met die in andere deelen van het Rijk. In 1875 (29 October) had opnieuw eene reorganisatie plaats, waarbij het toezicht overging op de orde van Santo Domingo (de Dominikanen) onder bescherming van den Gouverneur-Generaal. Aanvankelijk was Santo Tomás de Aquino schutspatroon. De faculteiten waren toen: rechtsgeleerdheid, kanoniek recht, theologie, geneeskunde, geneesmiddelenbereiding en notariaat.

De Universiteit van Habana (Cuba) werd in 1721 door Paus Innocentius XIII opgericht met dezelfde bevoegdheden als die van Salamanca en van Alcalá.

In 1535 en later kwamen tot stand speciale onderwijsinrichtingen voor zonen van inheemsche hoofden, waar vooral de Christelijke leer en de Spaansche taal op den voorgrond kwamen.

Sedert 1863 werd het onderwijs in de koloniën beheerscht door de in het moederland geldende beginselen.

\section{Geneeskundige dienst. ${ }^{1}$}

In 1570 verordende Filips II, dat in het belang der volksgezondheid naast de leerstoelen voor de geneeskunde in de koloniën, zouden worden aangesteld geneeskundige inspecteurs (proto-médicos). Sommigen hunner werden onderscheiden als generales, met een grooter ressort. In het moederland met zorg uitgekozen, hadden zij in de koloniën zich op de

1 Men vergelijke hierbij hetgeen in hoofdstuk IX voorkomt ten aanzien van de vereischten waaraan de plaatsen van vestiging uit een gezondheidsoogpunt hadden te voldoen. Ook in latere hoofdstukken vindt men bewijzen, dat de algemeene gezondheidstoestand in het oog gehouden werd, 
hoogte te stellen van alle geneeskrachtige planten en zaden, van de bijzondere eigenschappen daarvan, van de klimaten waar zij voorkomen, en van het nut dat daaruit getrokken wordt. Zooveel mogelijk zelf proeven nemende, en overigens zich verlatend op mededeelingen van anderen, vooral deskundigen, hadden zij aanteekening te houden van hunne bevindingen, en verzamelingen aan te leggen, ter opzending naar het moederland. Zij waren tevens belast met het examineeren van genees- en heelkundigen, met het toezicht op de apotheken en de daarin aanwezige geneesmiddelen, en met maatregelen ten bate van den algemeenen gezondheidstoestand. Voor het geval van overtredingen, waren $\mathrm{zij}$ vergezeld van een door de rechtbank aan te wijzen rechter-commissaris, die dadelijk uitspraak had te doen.

In 1646 werd het ambt van proto-médico opgedragen aan den eersten hoogleeraar der faculteit van Geneeskunde aan de universiteiten te Mexico en te Lima met een zeer uitgestrekt ressort. De benoeming geschiedde toen door den betrokken onderkoning.

In 1535 bestond de verbodsbepaling voor allen, die niet aan een der universiteiten van het moederland den titel van doctor, maestro of bachiller hadden verworven, om de genees- of heelkunde uit te oefenen. In 1579 en later in 1621 kregen de proto-médicos de bevoegdheid om vergunningen tot uitoefening uit te reiken, zoo noodig na het afnemen van een examen. Dit gold ook voor chirurgijns, apothekers, barbiers en «algebristas», die bij de beenbreuken een rol vervulden.

Opmerkelijk is het niet aantreffen van voorschriften betreffende besmettelijke ziekten en quarantaine, terwijl toch de wet der XII tafelen: salus populi suprema lex esto reeds in 1471 o. a. op het eiland Majorca aanleiding gaf tot het instellen van het ambt van morberos (morbus=ziekte), toen daar eene pest-epidemie uitbrak. De morberos vormden eene commissie van drie personen (een edelman, een militair en een koopman), bijgestaan door een geneesheer en heelmeester, met bevoegdheid de opneming van verdachte zieken in een lazaret te gelasten, en hunne kleederen te doen ontsmetten of verbranden. In 1692 en 1718 werden meer uitgebreide gezondheidscommissies benoemd. ${ }^{1}$

1 (Bover. Historia General del Reino de Mallorca I, 120). Wellicht mag uit het achterwege blijven van dergelijke maatregelen voor de Indias worden afgeleid, dat daar geen epidemiën voorgekomen waren, dan wel dat zij onherkend bleven. 


\section{Uitgave en invoer van boeken.}

Het drukken en naar de koloniën brengen van boeken over koloniale onderwerpen was alleen toegelaten met vergunning van den Raad van Indië. Tegen overtreding waren boeten bedreigd van 200.000 en 50.000 maravedis, ${ }^{1}$ gepaard met verbeurdverklaring van de drukkerij.

Zelfs boeken over de inheemsche talen mochten niet gedrukt noch gebruikt worden, zonder voorafgaand verlof. Zoo ook het drukken, invoeren, verkoopen en lezen van boeken met profanen inhoud (romans, verdichte verhalen, etc.).

Bij invoer van toegestane boeken moest elk exemplaar afzonderlijk worden geregistreerd. Elk binnenkomend schip werd aan een bijzonder boeken-onderzoek onderworpen. Dit onderzoek strekte zich zelfs uit tot gebeden-boeken, die uitsluitend mochten bezorgd worden door het klooster van San Lorenzo el Real. Ter voorkoming van misbruiken moest op de gebeden-boeken door de Casa de Contratación bij het vertrek der schepen toezicht worden gehouden.

Van elk in de koloniën met voorafgaande toestemming gedrukt boek moesten 20 exemplaren aan den Raad van Indië werden gezonden ter ronddeeling aan allen, die van dit College deel uitmaakten.

Voor de Filipijnen is nog in 1857 een besluit van den Gouverneur-Generaal gaan gelden, betreffende toezicht op den druk en op den invoer te Manila van elders uitgegeven boeken: strafbepalingen betreffen zoowel den verboden invoer als den inhoud, wanneer deze in strijd bleek met den godsdienst, de moraal of de wetten. Langzamerhand geraakte dit besluit echter in onbruik, en vond het alleen toepassing, wanneer bijzondere redenen daartoe aanleiding gaven.

Voor Cuba en Portorico golden eveneens censuur-voorschriften, zelfs nog in 1881.

Ook in het moederland bleven zij lang bestaan.

\section{Ontdekkingen en vestigingen.}

Het vierde boek begint met de ontdekkingen ter zee en te land. Als hoofdbeginsel werd door Filips II aanvaard, dat niet naar nieuwe ontdekkingen en nederzettingen moet worden

\footnotetext{
1 De maravedi was een koperen munt van $1 \frac{1}{2}$ centimo $=$ ongeveer $\frac{3}{4}$ cent.
} 
gestreefd, voordat de reeds bestaande kracht hebben verkregen. Het voornaamste voor oogen te houden doel behoort te zijn en te blijven: de prediking en verbreiding van het Katholieke geloof en de zorg dat de inboorlingen onderwijs krijgen en in vrede en rust leven ("que los indios sean enseñados, y vivan en paz y policía»).

Ontdekkingen en vestigingen moeten daarom plaats hebben op gezag van den Staat. De medewerking van vreemdelingen was hierbij uitgesloten.

Filips IV geeft in 1621 het van doorzicht getuigend voorschrift, dat in de verdragen het woord "verovering, (conquista) vermeden dient te worden; men spreke van vredestichting en vestiging ("pacificación y población»).

De ontdekkers hadden aan ontdekte landen, bergen, rivieren enz. namen te geven. Vergezeld van tolken, behooren zij zich op de hoogte te stellen van alles wat het nieuw gebied betreft, in de eerste plaats bijzonderheden omtrent godsdienst, zeden en gebruiken, taal en bestuursvormen enz. der inboorlingen; gesteldheid van den bodem; aanwezigheid van edele metalen en bruikbare planten. $\mathrm{Zij}$ hadden zich te wachten den inboorlingen in eenig opzicht overlast aan te doen en op het gebied te komen van andere ontdekkers. Van alle bevindingen moesten zij uitvoerig verslag uitbrengen aan den Raad van Indië.

Voor de ontdekkingen ter zee en te land bestonden afzonderlijke voorschriften. Ter zee moesten de schepen twee aan twee gaan om elkander te kunnen helpen. Elk schip behoorde twee geestelijken aan boord te hebben voor het bekeeringswerk, en moest minstens voor een jaar proviand medevoeren alsmede het noodige om verloren gaand tuig en andere onderdeelen te vervangen. Er moesten twee loodsen zijn, belast met het houden van aanteekening van alle waarnemingen. De bemanning mocht niet grooter zijn dan 30, en de scheepsmaat niet meer dan 60 ton. Ruilmiddelen waren aangegeven. Landing moest geschieden in overleg met elkander; inbezitneming in naam van den Koning.

Te land mocht ook alleen met toestemming van den Koning worden opgetreden. De hoofden van nieuwe vestigingen hadden meestal den titel van "adelantado, 1 , ook wel van «capitan" of «cabo» (hoofd). Vestigingen konden door een "adelantado»

1 Letterlijk: vooraanstaande. 
in het moederland worden voorbereid door het bijeenbrengen van vrijwilligers. Dergelijke troepen hadden recht op bijstand van de autoriteiten der plaatsen welke zij doortrokken en vanwaar het vertrek geschiedde. Levensmiddelen moesten tegen billijken prijs worden geleverd. Ook de Casa de Contratación ${ }^{1}$ te Sevilla had het welslagen in de hand te werken, zonder zich in te laten met de vrijwilligers. De "adelantado " had echter zorg te dragen dat dezen geen blaam trof uit hoofde van moorsche, joodsche of ongeloovige afkomst; dat zij niet door de Inquisitie gestraft waren; en dat zij niet behoorden tot de personen aan wie het verblijf in de koloniën ontzegd was.

Elk jaar mocht de "adelantado " twee schepen met slaven, wapens, levensmiddelen en vee ten behoeve van zijne vestiging en de daarin gelegen mijnen doen uitkomen, vrij van rechten. Binnen een aangegeven tijd moesten minstens drie steden en één provincie zijn opgericht, en zoo noodig ook versterkingen.

Het kommando hierover kon overgaan op den zoon, erfgenaam of opvolger van den *adelantado», met bezoldiging van den Staat. Andere noodig voorkomende ambten mochten door den "adelantado» worden vergeven, onder verplichting om binnen vier jaren de bevestiging van den Koning te vragen. Van de aanstelling van ambtenaren met financieele bevoegdheid moest den Koning dadelijk bericht worden gegeven.

De rechtspraak berustte bij den "adelantado». Zoo ook het uitvaardigen van bindende voorschriften, mits niet in strijd met algemeene verordeningen. Binnen twee jaren moest hierop de goedkeuring verkregen worden van den Raad van Indië, tot welken de "adelantado» in onmiddellijke verhouding stond.

Tot demping van onlusten mocht de "a de la n ta do» in overleg met de ambtenaren uit 's lands kas putten. Hij had van de ontgonnen metalen en waardevolle steenen $1 / 10$ der waarde op te brengen. Van de andere belastingen werd aan alle tot een nieuwe vestiging behoorende personen vrijstelling verleend gedurende tien dan wel twintig jaren.

Aan de "adelantados», die zich goed van hunne taak kweten, waren eeretitels beloofd, o. a. van markies. Bovendien hadden zij de bevoegdheid om van hetgeen zij verkregen uit opbrengsten van land- en mijnbouw, parelvisscherij enz. majoraten ${ }^{2}$ te vormen.

1 Zie hoofdstuk XIX.

2 Onvervreemdbare onroerende goederen, die op den oudsten zoon der 
Karel I (V) verklaart in 1543 tot eersten ontdekker van Mexico den kapitein-generaal Fernando Cortés, markies del Valle, en gelast dat alle ontdekkers met onderscheiding bejegend moeten worden. Filips II voegt hieraan toe, dat zij met hunne afstammelingen tot den Spaanschen adel (hijosdalgo de solar conocido) ${ }^{1}$ zullen behooren. Met het oog hierop gelast de Koning het aanhouden van een register waarin ieders verdienste wordt opgeteekend en het jaarlijks opzenden aan den Raad van Indië van een extract uit dit register.

Het doen van ontdekkingen in de richting van Brazilië werd in 1595 verboden. Eveneens pogingen om handelsbetrekkingen aan te knoopen. De reden hiervan is niet vermeld. Vermoedelijk hangt dit samen met moeilijke politieke verhoudingen welke het gevolg waren van de inlijving van Portugal en de Portugeesche koloniën bij Spanje in 1578.

Bij de "pacificaciones» (titel IV) wordt wederom aangedrongen op bestudeering van alles wat betrekking heeft op nieuw verworven gebied: taal, godsdienst, politieke verhoudingen enz.; op pogingen om door middel van handel en geschenken vriendschapsbetrekkingen te verkrijgen met de inheemsche heerschers; op prediking van het Katholiek geloof zonder eenige geweldpleging, met de meeste toegevendheid voor bestaande ondeugden, afgodendienst en veelwijverij. Eerst nadat de beginselen van den nieuwen godsdienst post beginnen te vatten, had men te trachten met zachtheid en overreding te verkrijgen dat afgeschaft wordt a!les wat in strijd is met het heilig geloof. Onderwijl geve men door christelijken levenswandel een goed voorbeeld. Tot bereiking van het doel konden de uitzending en tewerkstelling van geestelijken uit de schatkist worden bekostigd. Ook aan dezen werd op het hart gedrukt elk gewelddadig optreden te vermijden. Voor allen gold het verbod om van de

betrokken familie overgingen. Bij J. M. Palacios, Instituciones del derecho civil de Castilla, aanvankelijk bewerkt door Asso en Manuel (Madrid 1806), (I, 225), wordt als omschrijving van Molina aangehaald: „M a y or a z go es el derecho de suceder en los bienes que se dejan con la condición de perpetuarse en la familia, de modo que pase a cada primogenito por razon de sucesión". Hetgeen beteekent: Majoraat is het recht om op te volgen in de goederen die nagelaten zijn met de voorwaarde van bestendiging in de familie, met dien verstande dat zij bij wijze van erfopvolging overgaan op elken eerstgeborene. In 1646 stelde Gaspar de Criales vast, dat destijds de oudste majoraten ongeveer drie eeuwen bestonden.

1 Edellieden van erkende afkomst. Solar beţeekent letterlijk grond. 
inboorlingen iets te eischen en bewezen diensten onbetaald te laten. Ook vrijstelling van belastingen werd ten behoeve van de inboorlingen toegelaten, reeds onder Fernando V (1513).

Aangaande de plaatsen van vestiging ("poblaciones»), die te land en ter zee gemakkelijk bereikbaar moeten zijn, behoort vooraf vast te staan: ${ }^{1} 1^{\circ}$ dat de streek gezond is, hetgeen moet.blijken uit het aanwezig zijn van personen van hoogen ouderdom, en van jonge lieden die er forsch uitzien en een gezonde kleur hebben; $2^{\circ}$ dat het vee groot en flink is $; 3^{\circ}$ dat de vruchten en andere voedingsmiddelen goed en overvloedig zijn; $4^{\circ}$ dat de grond vruchtbaar is, en geen schadelijke en vergiftige planten voortbrengt; $5^{\circ}$ dat de lucht zuiver en verkwikkend is onder een helderen en weldadig aandoenden hemel; $6^{\circ}$ dat de temperatuur niet overmatig warm of koud is (het laatste verdient, indien het niet anders kan, de voorkeur); $7^{\circ}$ dat er geschikte weideplaatsen zijn, alsmede bergen, bosschen met bouwmaterialen, metaalafzettingen, en veel water voor drank en bevloeiing; en eindelijk eene bevolking geschikt om het Heilige Evangelie te ontvangen, hetgeen vóór alles het doel der vestiging behoort te zijn.

Bij niet-voldoening aan de gestelde eischen beliep het hoofd der vestiging een boete van 1000 goudpesos. ${ }^{2}$ In het omgekeerde geval, krijgt hij ten geschenke een stuk grond van vier mijlen in omtrek op vijf mijlen afstand van de vestiging. Gezorgd dient te worden dat dit geschenk geen nadeel aan inboorlingen of anderen toebrengt.

Jongelieden, die zich naar nieuwe vestigingen willen begeven, moeten, indien eenigszins mogelijk, gehuwd zijn en van hunne vrouw vergezeld worden. Binnen een vastgestelden termijn moet eene nieuwe vestiging minstens 30 Spaansche bewoners hebben; zijn zij allen gehuwd, dan is een aantal van tien voldoende; ieder behoort te hebben een huis met 10 koeien, 4 stieren, 1 merrie, 1 big, 20 schapen, 6 kippen en 1 haan.

De noodige beambten worden betaald uit 's lands kas. Op dezelfde wijze wordt voorzien in de kerkelijke benoodigdheden.

Afzonderlijke titels bevatten nog tal van meer in bijzonderheden gaande bepalingen en hygiënische voorschriften, die den indruk geven, dat reeds in het midden der $16^{\mathrm{e}}$ eeuw een helder inzicht bestond omtrent bevordering van de volksgezondheid.

Opmerking verdient het voorschrift om zich niet met de

1 Men vergelijke hierbij hetgeen in hoofdstuk VII is vermeld.

2 Tegenwoordige waarde ongeveer $=f 2.50$. 
inboorlingen in te laten dan nadat de vestiging geheel tot stand is gekomen. De bouw en inrichting der huizen moeten dan den inboorlingen bewondering afdwingen.

Reeds Fernando V bepaalde in 1513, en de op hem volgende vorsten herhaalden dit, dat bij de eerste vestiging in de koloniën huizen en erven alsmede stukken grond voor den tuinbouw geschikt en bevloeiingswater zouden zijn toe te kennen, grooter of kleiner, al naarmate de belangrijkheid der bewezen diensten. $\mathrm{Na}$ vier jaren gebruik, ontstond de bevoegdheid om het verkregene te gelde te maken, of daarover op andere wijze te beschikken. Vreemd genoeg, de overdracht mocht niet geschieden aan geestelijken of aan kloosterlingen.

De landvoogden waren bevoegd hierbij uit naam van den Koning te handelen, in overeenstemming met de Raden (Cabildos), (bl. 161) zonder schade toe te brengen aan de inboorlingen, die, afgescheiden hiervan, hunnerzijds ook aanspraak hadden op schenkingen. Het toegekende moest binnen 3 maanden op zichtbare wijze in gebruik worden genomen, op straffe van verval. Stukken grond, die zonder titel in bezit waren genomen, moesten tot het staatsdomein terugkeeren, dat als onmiddellijk gevolg van de verovering ontstond, dan wel tot de vroegere inheemsche rechthebbenden. Aan dezen mocht in geen geval nadeel worden toegebracht. Was dit geschied, dan behoorde herstel plaats te hebben. Nieuwe ontginningen mochten overigens niet worden toegestaan dan na behoorlijk onderzoek.

Aan nieuwe vestigingen mochten gronden in gemeenschappelijk eigendom ("propios») worden afgestaan, die dan weer vatbaar waren voor verpachting aan den hoogst biedende. Jaarlijks behoorde van die gronden rekening en verantwoording te worden ingezonden aan den Raad van Indië, na door een daartoe aangewezen ambtenaar te zijn goedgekeurd. Uit de opbrengsten konden o. a. voldaan worden de rouwkosten bij het overlijden van personen behoorende tot het Koninklijk Huis.

\section{$X$. Aanvoerders van gewapende en koopvaardijvloten en verder personeel. ${ }^{1}$}

Een uitvoerigen titel ( $\mathrm{XV}$ van boek 8 ) is aan dit onderwerp gewijd.

Er wordt telkens gesproken van armada en flota. Het

\footnotetext{
1 Men vergelijke hierbij hoofdstukken XI en XXIX.
} 
eerste woord ziet op de gewapende en het tweede op de koopvaardijschepen. $\mathrm{Zij}$ voeren te zamen, evenals in onzen Compagnie's tijd de convooien.

Aan het hoofd van het geheel stond een kapitein-generaal; een admiraal voerde het bevel over de gewapende schepen; en een "gobernador" over de koopvaardijschepen. $Z$ ij werden door den Koning benoemd en legden den eed van trouw af hetzij te Madrid, hetzij te Sevilla in handen van voorzitter en leden der $\mathrm{C}$ as a de Contratación. Dadelijk daarna traden zij in het genot van hun traktement tot de terugkeer uit de kolonie. $\mathrm{Zij}$ hadden, evenals de bevelhebbers der schepen, zekerheid te stellen; de kapitein-generaal tot een bedrag van 8000 dukaten, de admiraal tot een van 4000 dukaten, de andere bevelhebbers tot een van 2000 dukaten. Ook de lager geplaatsten hadden zekerheid te stellen tot verschillende bedragen van 1500 tot 300 dukaten. Alles in zilver berekend. Over en weder mocht men geen borg zijn. Niemand mocht zich inschepen voordat deze aangelegenheid behoorlijk was vastgesteld door den aangewezen "escribano" (schrijver).

Sedert 1640 moest de eed ook inhouden dat men niets aan boord zou medevoeren dan wat in de registers vermeld was, noch voor zich zelf, noch voor anderen. Na de eedsaflegging heesch men de vlaggen, en werden door tamboers en pijpers opgeroepen allen die de reis mede wilden maken.

De kapitein-generaal en de admiraal hadden er voor te zorgen, dat het vertrek op den bepaalden dag kon geschieden. Werden belemmeringen ondervonden, dan mochten zij zich wenden tot voorzitter en leden der Casa de Contratación, en zoo noodig zelfs tot den Raad van Indië. Overigens had elke gezaghebber te letten op het gereedkomen van zijn eigen schip.

De burgerlijke autoriteiten hadden zich niet in te laten met zaken de vloot betreffende. Deed zich een ernstig misdrijf voor, dan moesten zij dadelijk den opperbevelhebber daarmede in kennis stellen. Was deze afwezig, dan mochten zij voorloopig optreden en de zaak ter kennis brengen van den kolonialen Oorlogsraad (Junta de Guerra de Indias). Ook de niet met koloniale aangelegenheden te maken hebbende militaire bevelhebbers hadden dezelfde houding aan te nemen. Bleek het noodig manschappen tot de koloniale vloot behoorende in hechtenis te stellen, dan waren de plaatselijke autoriteiten 
verplicht aan de bevelen der vlootaanvoerders gehoor te geven.

Van de geschiktheid der aan te nemen manschappen hadden de bevelvoerders zich vooraf te overtuigen. Bepaaldelijk viel er op te letten, dat geen passagiers zich onder de manschappen verscholen. Hiertegen waren straffen bedreigd. Ook tegen het aan boord nemen van slaven.

De aanvoerders der koopvaardijvloten waren ondergeschikt aan die der armada. Voor onderscheiden gevallen die zich konden voordoen, waren bepalingen gemaakt betreffende den voorrang en het kommando. In het bijzonder wanneer in de koloniën vroeger aangekomen schepen zich bij de teruggaande aansloten. Stierf de kapitein-generaal gedurende de reis, dan trad de admiraal in diens plaats, terwijl deze op zijne beurt vervangen werd door den oudsten "gobernador".

De aanvoerders mochten geen handel drijven, noch in de koloniën, noch onder weg, en ook geen koopwaren medevoeren, op straffe van verbeurdverklaring van de helft hunner bezittingen en van verlies hunner waardigheid. Het was hun ook verboden geschenken te aanvaarden; van de landsgoederen en die aan bijzondere personen behoorende, iets voor eigen gebruik aan te wenden; en een deel der soldijen in voorschot te geven.

Was het waarschijnlijk, dat zeeroovers of vijandelijke schepen zouden worden ontmoet, dan moest vóbr het aanvaarden van de reis scheepsraad plaats hebben, waarbij ook de 'gobernador, tegenwoordig was. De maatregelen waartoe besloten was, hadden dan dadelijk toepassing te vinden. Er behoorde ook een vaartinstructie te worden vastgesteld in overleg met den admiraal en de scheepsgezaghebbers.

De kapitein-generaal had zijne ondergeschikte officieren met beleefdheid te behandelen, doch tevens was hij verplicht om de voorgeschreven instructies streng op te volgen en te doen gehoorzamen. Bij het aandoen van eenige haven moest niet meer volk aan wal gaan dan strikt noodzakelijk, en in elk geval zonder goederen van waarde mede te nemen.

Bij terugkeer in het moederland, moesten de bevelhebbers en andere officieren gedurende 60 dagen beschikbaar blijven voor de afwikkeling van alle zaken, betrekking hebbende op de afgelegde heen- en terugreis, met verplichting om van al het verrichte mededeeling te doen aan den Raad van Indië.

In 1674 werden nieuwe instructies voor de bevelhebbers en Dl. 79. 
andere officieren vastgesteld, die een 40-tal bladzijden druks beslaan. $\mathrm{Zij}$ betroffen achtereenvolgens de eedsaflegging; de af kondiging van bevelen met tamboers en pijpers in naam van den Koning, o.a. tot het bijeenbrengen van scheepsvolk en manschappen; hunne indeeling over de schepen; de inspectie der schepen, en de hierbij in acht te nemen voorzorgen zoowel vóór als gedurende de reis; zuinig gebruik van kruit bij de begroetingen; de infanterie-oefeningen; voorzorgen tegen brand en desertie; voorschriften voor de scheepvaart en de krijgsbedrijven; de scheeps-oefeningen; de maatregelen bij het ontdekken aan boord van personen die er niet tehuis behooren, in het bijzonder van negerslaven; het verbod van handel drijven en verkoop van wapens en mondvoorraad; de verplichte verrichtingen in verschillende havens; de daar aangetroffen schepen zonder verlof varende; het samenvoegen van eskaders en den daarbij in acht te nemen voorrang; de rangopvolging in bijeeneenkomsten; de tijdelijke vervangingen; de maatregelen ingeval van bericht dat vijandelijke overvallen te verwachten waren.

Aan boord bevond zich een "veedor» en een "contador, of "pagador», belast met het doen van inkoopen en betalingen en het voeren van verdere administratie.

Omtrent den "veedor» en "contador» 1 der vloot wordt nog aangegeven, dat zij belast waren met het opmaken van rekeningen en de boekhouding, de eerste in het bijzonder voor alles wat de oorlogschepen betrof alsmede de bemanning daarvan; o.a. had hij bij het uitzeilen na te gaan of allen aan boord waren, en vast te stellen dat niets was ingescheept in strijd met de voorschriften. Hij had ook de koopvaardijschepen te inspecteeren, telkens wanneer hij dit noodig oordeelde. Verder was hij belast met den aankoop en de in ontvangstneming van mondvoorraad en de boekhouding daarvan; zoo ook van de vaten wijn en azijn. Op reis moest hij zorgen, dat hetgeen aan bederf onderhevig was, het eerst verbruikt werd. Hij had ook zorg te dragen voor de zieken, de medicijnen en de extra-voeding; voor de bergplaatsen van kruit, voor de overlading ingeval een schip verlaten moest worden, enz. De aanteekeningen en de uitbetalingen waren vooral aan den scontador opgedragen.

Boven den "veedor" en den "contador" stond in de Casa de Contratación te Sevilla een "proveedor"

1 Toezichthouder en rekenaar. 
(oppertoezichthouder), die in overleg met den eersten "escribano» (schrijver) de rekeningen van voormelde twee na goedkeuring doorzond aan het College en ook belast was met de regeling van de "avería». ${ }^{1} \mathrm{Bij}$ de inkoopen, waarbij ook de " factor " ${ }^{2}$ van het College medewerking verleende, moest gelet worden op goede hoedanigheid, in het bijzonder van de geneesmiddelen. Ook was te zorgen voor voldoende drinkwater.

De betaalmeester ("pagador») mocht zich bij het vertrek en gedurende de reizen op eigen kosten en op zijne verantwoordelijkheid doen vertegenwoordigen; hij was verantwoording schuldig aan den «contadors.

Er waren drie geldkisten, elk met drie verschillende sleutels in het bezit van den "pagador», den "contador de avería" en den "contador diputado" of "veedor" voor onderscheiden diensten.

Ook worden genoemd: twee «tenedores» (magazijnmeesters), die telkens voor twee jaren belast waren met het in ontvangst nemen van den op last van den proveedor aangekochte levensmiddelen, munitie, wapens en ander oorlogsmateriaal, waarvan de veedor en de contador in hunne boeken aanteekening hadden te houden. Ook van hetgeen door den "factor, op rekening van de avería werd aangeschaft. Dit moest afzonderlijk worden opgeborgen. Alles wat na afloop van eene reis terugkwam, ook de kanonnen en verder oorlogsmateriaal, werd door de tenedores opgeborgen, en zoo noodig door den factor en den proveedor hersteld, met dien verstande dat afgescheiden werd gehouden wat aan de avería en wat aan den Staat toekwam.

Alle handelingen van eenig belang werden door den sescribano mayor voor de oorlogschepen, dan wel door een der andere "escribanos" voor de koopvaardijschepen in schrift gesteld met inachtneming van een aantal bepalingen.

Talrijke voorschriften werden gegeven voor de scheepsgezaghebbers en hun ondergeschikt personeel. In het bijzonder viel er op te letten, dat de soldaten geen vrouwen medenamen, niet vloekten of andere zonden begingen; dat zij zich ordelijk gedroegen en hunne inkoopen betaalden. Ook bij de aanwerving had men er op te letten, dat alleen behoorlijke personen in dienst kwamen. Er mochten geen opkoopers van kleeren enz. binnen sluipen.

1 Zie hoofdstuk XII.

2 Factor is het best weer te geven door het woord commissionair. 
Verder voorschriften voor het onder dak brengen van militairen bij ontscheping of landmarschen, bij desertie en andere gevallen.

De kapitein-generaal der artillerie van het $R i j k$ had sedert 1626 het kommando over al het oorlogsmateriaal en het personeel der voor de koloniën bestemde vloot, en moest door alle autoriteiten gehoorzaamd worden. Onder zijne directe bevelen had hij een "veedor» en een "contador" der artillerie een "artillero mayor», een "pagador» en enkele anderen. De "artillero mayor" was tevens belast met de zware bewapening der koopvaardijschepen.

Verbonden aan de Casa de Contratación was een "piloto mayor» (Opperloods) te benoemen na een vergelijkend examen, en een cursus over kosmografie en scheepvaartkunde. De met dezen cursus belaste personen hadden maandelijks samen te komen met den "piloto mayor" om de voor den verkoop bestemde kaarten en scheepsinstrumenten te inspecteeren, en hiervan op bepaalde wijze te doen blijken.

Het examen voor zeelieden werd in de Casa de Contratación gehouden, ten overstaan van een der "escribanos», door den "piloto mayor», den "mayordomo" (administrateur) en de "diputados" van de "Universidad de los mareantes». ${ }^{1}$ De stemming over de toelating geschiedde "por haba y altramuz» ${ }^{2}$ De candidaten moesten gedurende tien maanden den voormelden cursus hebben gevolgd.

De "piloto mayor" en de onder hem gestelde loodsen hadden denzelfden rang als de "artillero mayor». $\mathrm{Zij}$ moesten van alle reizen zeevaartkundige aanteekeningen houden en hieromtrent inlichtingen geven aan voormelde cosmografen.

Er waren tevens "maestres de raciones", (rantsoenmeesters), die toezicht hadden te houden over de levensmiddelen, en de overige voorraden. Onderscheidene voorschriften bestonden voor water, wijn, enz., munitie en verder oorlogsmateriaal. Ook over het medenemen van aangenomen personeel, o. a. een geneesheer, een heelmeester, een apotheker en ziekenverplegers, een kapelaan enz.

Elk jaar moesten sedert 1561 twee koopvaardijvloten naar de Indias vertrekken, de een naar Nueva España (Mexico), de ander naar Tierra Firme (eene landvoogdij, welke zich uitstrekte over een

1 Zie hoofdstuk XXI.

2 Witte en zwarte boonen. 
deel van het vasteland van Zuid- en Midden-Amerika), telkens begeleid door eene armada, sterk genoeg voor de verdediging tegen vijandelijke aanvallen. De keuze der aanvoerders en gezaghebbers door de Casa de Contratación, te bevestigen door den Raad van Indië, viel bij voorkeur op hen, die reeds 6 jạren dienst hadden en eigenaren der schepen waren. De koopvaardijschepen moesten minstens 300 ton groot zijn, en met zorg uitgekozen worden ter goedkeuring door den Raad van Indië. Vreemde schepen mochten niet op de Indias varen op straffe van verbeurdverklaring met lading en al, ook al behoorde de lading aan Spanjaarden toe.

De mede te voeren kanonnen waren van vier afmetingen al naar mate de scheepstonnemaat.

\section{Voorschriften omtrent de scheepvaart.}

\section{§ 1. Verlof voor het vertrek.}

Niemand mocht zonder verlof van den Koning of van de Casa de Contratación ${ }^{1}$ naar de koloniën vertrekken. Dit gold ook voor de geestelijken. Ingeval van overtreding verloor men al zijne bezittingen ten bate van de schatkist na aftrek van $\frac{1}{5}$ voor den aangever, en werd men uit de koloniën verwijderd. Het goederenverlies werd ook toegepast op hen wier overtreding eerst bleek na terugkeer in het moederland. Ook de scheepsautoriteiten werden bestraft, indien bleek dat zij passagiers mede hadden genomen zonder op het voorschrift te letten. Het verlof gold gedurende twee jaren. Eene oude bepaling van 1522 was: dat voor Mooren en Joden, die kort te voren tot de katholieke kerk waren overgegaan, en hunne kinderen, een uitdrukkelijk verlof van den Koning gevorderd werd, zoo ook voor slaven en mulatten, en dat afstammelingen van door de Inquisitie veroordeelden in geen geval toegelaten werden en bij overtreding al hunne goederen verloren.

Tal van voorschriften betroffen het al of niet medenemen van gehuwde vrouwen.

Vreemdelingen mochten niet in de koloniën handel drijven, noch uit anderen hoofde daar komen. Zelfs de doodstraf was hiertegen bedreigd, met verbeurdverklaring van alle goederen. In verband met dit verbod werd in 1620 bepaald, dat kinderen van vreemde-

1 Zie hoofdstuk XIX. 
lingen, in Spanje geboren, als Spanjaarden werden beschouwd. Vreemdelingen mochten ook niet als scheepsvolk worden aangenomen, met uitzondering van "levantiscos, (bewoners van de Levant) wanneer geen landslieden te krijgen waren. Deze laatsten mochten niet op vreemde schepen dienen. Aan boord van elk schip mochten 2 of 3 negerslaven van Guinea heen en terug worden medegevoerd.

Een maand vóór het vertrek moesten allen die de reis zouden medemaken biechten en communiceeren.

De schepen, die zonder verlof uit andere havens dan Sevilla en Cadix (Sanlúcar) naar de koloniën voeren, werden met de lading verbeurd verklaard, terwijl de daarbij betrokken personen bovendien straf ondergingen. Hetzelfde geschiedde met vijandelijke schepen, die op reis buit werden gemaakt. De bemanning werd òf gedood òf gevankelijk medegevoerd.

\section{§ 2. Passagiers.}

De passagiers moesten voorzien zijn van een geweer met de noodige munitie en hadden een eed af te leggen, dat zij niet zonder verlof het schip zouden verlaten of in eenige haven achterblijven. Overtreding bracht mede verlies van de helft der bezittingen en wat verder geraden zou blijken. $Z \mathrm{ij}$ werden op reis geoefend in den wapenhandel om ingeval van aanvallen aan de verdediging te kunnen deelnemen. Van passagiers mocht overigens eerst sprake zijn, wanneer bleek dat er na inschrijving van het scheepsvolk en de troepen plaats over was. De passagiers mochten niet mede eten van de levensmiddelen voor de troepen bestemd, die in voorgeschreven hoeveelheden moesten worden toegediend. Voor hen moest afzonderlijke voeding worden medegenomen. Vooral viel te letten op het aan boord nemen van voldoende hoeveelheden voedsel om te kunnen doorvaren zonder de Canarische eilanden aan te doen. Werden deze toch aangedaan, dan moesten de schepen vóór het vertrek van daar opnieuw onderzocht worden op het al of niet aan boord hebben van verboden goederen. Het was streng verboden om bij het aandoen van eenige haven levensmiddelen, wapens en munitie te verkoopen.

Geestelijken mochten niet in gewone kleeding medegaan. Er moest echter gezorgd worden voor het aan boord hebben van een geestelijke op elk schip, die ook belast was met geneeskundige hulpverleening (het toezien op het innemen van medi- 
cijnen, en op het diëet) en het opmaken van testamenten. Stierf iemand aan boord, dan had de geestelijke de bezittingen te bewaren nadat daarvan ten overstaan van een escribano, een inventaris was opgemaakt. Bij terugkeer in Sevilla werd alles in handen gesteld van den Fiskaal der Casa de Contratación.

Gehuwden, wier vrouwen in het moederland verbleven, mochten uit de koloniën medegenomen worden op last der plaatselijke autoriteit om te Sevilla aan de Casa de Contratación te worden uitgeleverd ${ }^{1}$. De behoeftigen onder hen mochten als soldaten medegaan.

\section{§ 3. Passagekosten en vrachtprijzen.}

De Leyes de Indias bevatten geen opgaven van hetgeen door passagiers en voor vracht verschuldigd was; niettegenstaande een afzonderlijke titel hieraan gewijd is. Men vindt slechts vermeld dat een en ander vastgesteld werd in onderling overleg, en dat de vracht voor zilver tot 1615 nooit meer bedragen heeft dan 1 pCt. der waarde en $1 \frac{1}{2}$ peso ${ }^{2}$ voor aangegeven hoeveelheden wol. Het was wel eens voorgekomen, dat onder weg door de scheepsgezaghebbers meer passagegeld werd geëischt dan vóór de reis was bedongen. Hiertegen kwam een verbodsbepaling met verbeurte van het reeds voldane. Men mocht ook niet eenmaal ten vervoer aangenomen lading laten liggen.

\section{§ 4. Lading en lossing.}

In de Casa de Contratación werd al het ingeladene in registers ingeschreven, welke mede aan boord genomen werden om bij aankomst de lading te kunnen verifieeren. Ook de inladers hadden beeedigde lijsten in voorgeschreven vorm op te maken en door de gezaghebbers te doen teekenen en in te leveren bij de Casa de Contratación, waar zij door den 'contador, en een «escribano» werden gewaarmerkt en bij den Raad van Indië ingediend. Van een en ander gingen afschriften naar de Indias, opdat daar blijke dat de lading goedgekeurd was. Ook van de passagiers moest een lijst worden opgemaakt met vermelding van de voor de inscheping verkregen toestemming.

Hetgeen uit de Indias naar het moederland werd afgescheept, moest op gelijke wijze worden geregistreerd met bijzondere

1 Men vergelijke hierbij hetgeen o. a. voorkomt op bl. 112.

2 Zie blz. 165. 
vermelding van het te vervoeren goud en zilver, de edelsteenen, parels en andere koopwaren. Deze registers en verdere stukken, op te maken ten overstaan van de "oficiales reales, en “escribanos» werden ook bij de Casa de Contratación ingeleverd. Van deze lading mocht onderweg niets verkocht worden. Bij pogingen daartoe kon de kapitein-generaal den gezaghebber naar een ander schip overplaatsen. Zoo ook wanneer niet geregistreerde lading werd ingenomen. Bij terugkeer werd vier jaren stilstand van werkkring als straf opgelegd. De eigenaren dezer op onrechtmatige wijze ingeladen goederen werden gestraft met verbeurdverklaring van al hunne goederen en verbanning.

Niets mocht voor de uitreis ingeladen worden voordat de goedkeuring van de $\mathrm{Cas}$ a de Contratación verkregen was. Daarna moest weder een onderzoek geschieden, waarvan rapport uit te brengen. Vóór het vertrek moesten op nieuw twee onderzoeken plaats hebben, welke ook betrekking hadden op het schip zelf, het eerste te Sevilla, het tweede te Sanlúcar, even vóor het in zee gaan. Een der leden van de Casa de Contratación moest zoo ver mogelijk medegaan. Bij het ontladen in de Indias werd de tegenwoordigheid van een oficial real of een oidor vereischt onder toezicht van de scheepsautoriteiten en de "escribanos de registros». Bij het eerste onderzoek had de kapitein een eed af te leggen, dat hij niemand aan boord had zonder verlof.

De onderzoekingskosten bedroegen telkens 50.000 maravedis en werden gekweten uit de avería, ${ }^{1}$ indien de boetekas van de Casa de Contratación niet genoeg bevatte. Het herhaald onderzoek betrof ook de oorlogschepen.

Zonder verlof mocht geen bewerkt goud, zilver of ijzer naar de koloniën worden uitgevoerd. Evenmin wapens.

Bij aankomst in het moederland werd ook een onderzoek van de schepen vereischt, en wel dadelijk, voorafgegaan door de beëediging van alle aan boord zijnde personen door een der leden van de Casa de Contratación, dat niemand op reis het schip had verlaten, dat niemand goud, zilver, edelgesteenten of parels bij zich had buiten de hoeveelheden in de registers vermeld, dat niemand zich door een vrouw of door inboorlingen had laten vergezellen, dat geen verboden spelen hadden plaats gehad en geen misdrijven waren voorgevallen.

\footnotetext{
1 Zie hoofdstuk XII.
} 
Oorlogschepen mochten sedert 1598 geen koopwaren overvoeren onder bedreiging van zware straffen.

Alleen de kapiteins (maestres) mochten doen inladen. Alle anderen, zelfs hooggeplaatsten, waren hiervan uitgesloten. Ook de onderkoningen moesten doen blijken, dat zij niet meer medevoerden dan hetgeen strikt noodzakelijk was.

Ingeval een koopman overleed, die een deel der lading had op te vorderen, zonder dat hij bij testament de rechthebbenden had aangewezen, dan benoemde de bevelhebber iemand, die tegen zekerheidstelling de lading in ontvangst moest nemen. Deze werd in het openbaar verkocht ten overstaan van de twee hoogste bevelhebbers, waarna de opbrengst werd uitgekeerd aan voorzitter en leden der Casa de Contratación. Was de overledene een der officieren, dan werd ook iemand aangewezen om zich met zijne nalatenschap in te laten totdat de rechthebbenden zich konden doen gelden.

\section{\$5. Scheepsbouw en onderhoud van schepen.}

Te Sevilla moest steeds aanwezig zijn een "maestro mayor», voor het toezicht op alle ambachten met den scheepsbouw in verband staande. Bovendien waren voorgeschreven een 50-tal opzichters, jaarlijks door de Universidad de mareantes ${ }^{1}$ aan te stellen.

In 1597 werd de toelage van 4000 dukaten per schip voor de scheepsbouwmeesters met $\frac{1}{3}$ verhoogd, met bepaling dat de toelage na drie jaren teruggegeven moest worden, indien het schip inmiddels verkocht was. Daarentegen mocht gedurende dien tijd het schip niet beladen worden ten voordeele van den eigenaar. Het vernieuwen van oude schepen was aan beperkingen onderhevig. Ook voor het bouwen van nieuwe schepen bestonden bepalingen, om te kunnen voldoen aan gestelde eischen, welker nakoming beoordeeld werd door een "arqueador» (scheepsmeter) en een "medidor» (meter).

Het veranderen van een koopvaardijschip in een oorlogschip geschiedde voor rekening van den Staat, tenzij de verandering voor slechts één reis geschiedde tegen een vastgesteld bedrag.

Voor het toezicht op de «jarcia» (tuigage en materiaal voor het kalfaten) in het geheele Rijk, mocht de Universidad de

1 Zie hoofdstuk XXI. 
mareantes ${ }^{1}$ met goedkeuring van president en leden der Casa de Contratación een inspecteur aanwijzen. De jarcia moest aan vastgestelde vereischten voldoen. Vóór de inspectie mocht de jarcia niet bepekt worden op straffe van verbeurdverklaring en 500 dukaten boete. Ook het vermengen met oude kabels was verboden.

\section{$\S 6$. Voorschriften gedurende de reis.}

Op reis moesten de kapiteins - indien mogelijk - twee malen daags het kommandoschip bezoeken om het wachtwoord te vernemen. Geen enkel schip mocht voormeld schip voorbij zeilen. Geschiedde dit toch, en wel in die mate dat daaruit verwarring kon ontstaan, dan beliep de kapitein eene boete van 50.000 maravedis en twee jaren verlies van betrekking. Bleek van opzet, dan was zelfs de doodstraf met verbeurdverklaring van alle goederen toepasselijk. De admiraal had dagelijks twee malen zijn schip in de nabijheid te brengen van dat van den kapiteingeneraal om zoo noodig overleg te plegen. Zooveel mogelijk moesten al de schepen in elkanders bereik blijven om over en weder hulp te kunnen verleenen en den vijand te bestrijden. Met het oog op dit laatste was bepaald, dat bij het naderen van de Azoren alle schepen in staat van verdediging moesten worden gebracht met inachtneming van bijzondere voorschriften. Bij het naderen van de Spaansche kust sloot het admiraalschip de linie, zoodat alle schepen waren vervat tusschen dit en het kommandoschip waarop de kapitein-generaal zich bevond. Het werd beschouwd als voorbehoedmiddel tegen het wegsmokkelen van goederen. In verband hiermede mochten ook geen schepen of booten de vloot tegemoet varen. Een bijzondere wacht was hiertegen voorgeschreven. Niemand mocht de op een aangewezen deel der haven voor anker gaande schepen verlaten voor dat het onderzoek had plaats gehad. Dadelijk werd van de aankomst bericht gezonden aan de Casa de Contrata ción, den Raad van Indië, en vervolgens ook aan den Koning met opgave van al het aangebrachte en van de nieuwstijdingen.

Van elke aankomst in het moederland werd aan de koloniale besturen bericht gezonden door een adviesschip van hoogstens 60 ton, zonder passagiers, met de noodige verdedigingsmiddelen.

1 Zie hoofdstuk XXI. 
De eigenaar had zekerheid te stellen voor de dadelijke terugkeer, en mocht geen Portugees zijn. Wederkeerig werd uit de koloniën bericht gezonden naar het moederland van aangekomen vloten. De kosten kwamen voor rekening van de avería.

Schepen, die zich van de vloot afscheidden en elders binnenliepen dan de bestemming medebracht, werden met de lading verbeurdverklaard. Hetzelfde geschiedde, wanneer schepen uit het moederland naar eenige haven der Canarische eilanden vertrokken, zich zonder verlof vandaar naar de koloniën begaven, het doende voorkomen alsof stormen dan wel andere van den wil der gezagvoerders onafhankelijke omstandigheden dit noodzakelijk maakten. Tevens beliepen de betrokken personen zeer zware straffen, evenals al diegenen die met zoodanige schepen handel gedreven hadden. Het binnenloopen van Portugeesche havens zonder noodzaak was eveneens verboden. Alle zaken betrekking hebbende op schepen als laatst bedoeld waren onttrokken aan den gewonen rechter en ter berechting opgedragen aan de Casa de Contratación in eersten aanleg, en aan den Raad van Indië in hooger beroep. Schipbreuk lijdende schepen moesten zoo spoedig mogelijk ontladen worden, terwijl in de naaste haven de noodige maatregelen waren te treffen ten aanzien van de geredde lading.

Een aantal voorschriften betroffen de tucht aan boord, de formaliteiten bij aankomst en gedurende het verblijf in de koloniën, o. a. dat de bevelen van den onderkoning dan wel van de 'Audiencias, moeten worden gehoorzaamd; dat de lossing en wederinlading met spoed behooren te geschieden; dat aangetroffen schepen nagezien en bewaakt worden; dat de bemanningen aan wal geen deel nemen aan feesten en stierengevechten; dat gewaakt wordt tegen den handel met vreemdelingen; dat de schepen voor inlading van groote waarden goed uitgezocht worden.

In burgerlijke gedingen was de rechter van den gedaagde de bevoegde, indien niet beide partijen tot de vloot behoorden. De eischer had overigens de keuze tusschen den vlootrechter en dien van den wal. Strafzaken werden aan boord berecht, behalve wanneer het betrof de ontduiking van landsverplichtingen.

In het bijzonder wordt vermeld, dat een ingescheepte onderkoning, al had hij den titel van kapitein-generaal, aan boord geen gezag mocht doen gelden. 
Goud, zilver en kostbaarheden moesten op oorlogschepen, en niet op koopvaardijschepen worden ingeladen.

\section{§ 7. Verzekering.}

Verzekeringen betreffende op de koloniën varende schepen werden reeds in 1555 geregeld. De "corredores" (convooiloopers), die de polissen bezorgden, hadden op straffe van geldboete bepaalde vormen in acht te nemen. Zij teekenden de polissen mede, maar mochten in geen enkel opzicht aansprakelijk zijn voor beloopen schade. Geschut en scheepsbenoodigdheden waren niet voor verzekering vatbaar; wèl het schip (c a s c o).

Op de waarde van het schip mocht de eigenaar of de gezagvoerder niet meer dan $\frac{1}{3}$ opnemen, zulks alleen met toestemming van het Consulaat (Consulado de mar) ${ }^{1}$ te Sevilla.

$\mathrm{Na} 1 \frac{1}{2}$ jaar werd een verzekerd schip waarvan geen bericht ontvangen was, als verloren beschouwd. Het verzekerd bedrag was dan verschuldigd behoudens verplichting van den verzekerde om van het schip ten behoeve van den verzekeraar afstand te doen. Vroegere verzekeringen moesten in de polis vermeld worden. Averij, veroorzaakt door beschadiging, was voor rekening van den inlader; alleen averij.grosse werd door den verzekeraar vergoed. Als verloren lading was slechts te beschouwen hetgeen ten overstaan van den escribano de registros, was ingeschreven. Alle niet in het daarvoor bestaande register ingeschreven polissen waren nietig. Verzekeringen van slaven en beesten behoefden uitdrukkelijke vermelding. Voor de polissen waren bovendien lange formules vastgesteld, welke aanvingen met de woorden: "In Dei Nomine, Amen s en op onderscheiden gevallen betrekking hadden. De risico begon dadelijk na de inlading en liep door tot de lossing. $\mathrm{Zij}$ verviel voor schepen, die eigenmachtig om de Kaap Verdische eilanden gingen. Overigens gold zij voor storm, brand, vijandige aanranding, en alle andere gevallen behalve verborgen gebreken. Kosten van overlading ingeval van gevaar kwamen voor den verzekerde.

\section{§ 8. Havens.}

De voornaamste havens werden uit nabijzijnde hoogten bewaakt. Over dag werden seinen gegeven met rook; bij nacht met vuren. Op sommige plaatsen werden ook merkteekens

\footnotetext{
1 Hoofdstuk XX.
} 
geplaatst. Aan den ingang van havens en rivieren mocht geen ballast in zee worden geworpen. Voor sommige havens was de toegestane tonnenmaat voor binnenloopende schepen aangegeven. $\mathrm{Bij}$ nacht was het binnenkomen verboden. Alle prijsgegeven scheepsbenoodigdheden mochten voor de forten dienen. Ankeragegelden en andere havenheffingen behoefden een koninklijk besluit.

\section{Avería (Omslag van beschermingskosten der koopvaardijvloten).}

De avería was eene heffing, welker ontstaan in den $9^{\text {en }}$ titel van boek 8 als volgt verklaard wordt: met de toeneming van handel en scheepvaart tusschen moederland en koloniën hielden gelijken tred de pogingen van andere zijde om de schepen met rijke ladingen buit te maken. Het werd daardoor noodzakelijk om de schepen vereenigd met elkander te doen varen onder beschutting van oorlogsvaartuigen, die voortdurend krachtiger bewapend en bemand moesten worden. Het werd billijk geacht, dat de groote kosten hierdoor veroorzaakt omgeslagen werden over de belanghebbenden bij de lading, en wel in verband met de waarde welke deze voor ieder vertegenwoordigde. Ook de Staat had op denzelfden grondslag zijn aandeel te voldoen, door tusschenkomst van ambtenaren, ondergeschikt aan de $\mathrm{C}$ as a de Contratación, en onder oppertoezicht van den Raad van Indië; enkele malen ingevolge bijzondere overeenkomsten gesloten met het Consulaat (Consulado de mar) te Sevilla. Uit de bijeen gebrachte gelden werd ook pondpondsgewijze vergoed de schade door stormen en later blijkende minderheden geleden.

De ontvanger ("receptor») van de avería had zekerheid te stellen voor een bedrag van 30.000 dukaten en in handen van voorzitter en leden der Casa de Contratación den eed af te leggen van getrouwe plichtsvervulling.

Met de vaststelling van het te betalen bedrag, de verdeeling van beloopen schade en de berechting der hierbij opkomende geschillen was een der "Jueces letrados» van de Casa de Contratación belast. Bleek de verschuldigde bijdrage hooger dan $12 \%$, dan werd het overige uit de schatkist voldaan. Voor het goud bedroeg de bijdrage slechts $2 \%$. Voor passagiers, van welken rang of stand ook, vrijen dan wel slaven, was 20 dukaten verschuldigd. In het ladingsregister mocht niets 
worden ingeschreven, indien niet vooraf de avería betaald was. De beslissing van geschillen betreffende avería was aan den gewonen rechter en aan alle geestelijke en militaire autoriteiten onttrokken, en uitsluitend opgedragen aan de rechtsmacht van de $\mathrm{C}$ as a de Contratación. Rezen dergelijke geschillen in de koloniën, dan berustte de berechting bij de hoogste administratieve en militaire ambtenaren. Ingeval van bedriegelijke aangifte werd de alsnog verschuldigde avería uit de betrokken lading gekweten. In 1635 werden van deze heffing uitgezonderd de voorwerpen van waarde bestemd voor kerken en heiligdommen. Ook van hetgeen aan het scheepsvolk toekwam, was zij niet verschuldigd. Alleen de scheepseigenaren en hunne familieleden, die medevoeren, hadden mede te betalen, tenzij zij uitdrukkelijk door de Casa de Contratación werden vrijgesteld. Voor ijzer en gips was niets verschuldigd.

Er waren twee "contadores de la avería" onder een "contador mayor" (hoofd-contador), die moesten zorgen voor de inning en uitbetaling van hetgeen voor de vloot noodig was, alsmede voor het nazien der rekeningen voor de vloot, alles onder oppertoezicht van de Casa de Contratación. Bij verschil van opvatting werd die van de meerderheid gevolgd, terwijl bij staking van stemmen het oordeel werd ingeroepen van het oudste juridisch lid (Juez letrado), tenzij de betrokken personen de uitspraak wenschten van het geheele College. Van alle koopwaren en andere goederen, die naar de koloniën werden uitgevoerd, dan wel vandaar werden ingevoerd, werd eene heffing gedaan van een zeker percentage, dat hetzij vooraf bedongen was, dan wel telkens vastgesteld werd. Op bepaalde tijdstippen werden de rekeningen en boekhoudingen nagegaan en na goedkeuring aan den Raad van Indië ingediend. De contadores ontvingen evenals de leden der Casa de Contratación drie malen 's jaars eene propina (toelage of gratificatie) waarvan het bedrag niet vermeld is.

Wel is bepaald, dat in dienst moest zijn een ambtenaar belast met het aanteekenen van de fouten die de contadores maakten (un apuntador de las faltas que hicieron los contadores). Deze had een inkomen van 10.000 maravedis.

De contadores mochten volgens eene bepaling van 1571 te Madrid een letrado (juridisch adviseur) en een procurador (gemachtigde) hebben voor werkzaamheden aan de avería 
verbonden. $\mathrm{Zij}$ mochten aan dezen een billijk inkomen toekennen, te voldoen uit de gelden voor de avería opgebracht. Op hunne voordracht kon door den Raad van Indië een solicitador (procureur) worden aangesteld op 200 dukaten voor de behartiging van zich voordoende geschillen.

Uit de avería-gelden mocht maandelijks een bedrag van 200 dukaten onder het scheepsvolk verdeeld worden.

\section{Spanjaarden en andere van buiten komende bewoners der overzeesche gewesten.}

\section{§ 1. Maatschappelijke afscheiding.}

In stede van de aaneensluiting der Europeesche bevolking, die men geneigd is te verwachten, bestond in het maatschappelijk leven een zeer sterke afscheiding, niet alleen door de gewoonte, maar zelfs krachtens de wet.

Zoo bijv. was het aan rechterlijke ambtenaren en andere aanzienlijke staatsdienaren verboden om bezoeken te brengen aan niet-ambtelijke personen, al waren dezen buren, en al was er geen sprake van eenig geschil. $\mathrm{Zij}$ mochten ook geen huwelijken en begrafenissen bijwonen dan in zeer bijzondere en noodzakelijke gevallen («en casos muy señalados y forzosos $)$ ). Bij openbare feesten en kerkelijke bijeenkomsten mochten zij alleen en corps verschijnen. Als eenige reden wordt in 1634 opgegeven, dat dit in het belang is van den dienst des Konings ("porque conviene a nuestro Real servicio»).

Ook met advocaten en procureurs mochten de rechters (oidores) en (alcaldes del crimen) niet omgaan.

Huwelijken tusschen de autoriteiten en particulieren waren zonder uitdrukkelijke vergunning des Konings verboden. Dit gold zelfs voor de zoons en dochters der ambtsbekleeders. Zulks opdat deze laatsten hun ambt kunnen uitoefenen zonder aanzien des persoons ("para que sin afición hagan y ejerzan lo que es á su cargo»). Overtredingen waren met verlies van het ambt bedreigd, ook al betrof het eene verloving.

Het ceremonieel in de kerken en daarbuiten ten opzichte van de verschillende ambtsbekleeders onderling was tot in kleinigheden geregeld. Het $3^{\text {e }}$ boek bevat een uitvoerigen titel 
(XV) betreffende den ambtelijken voorrang, de ceremonies en beleefdheidsuitingen, in sommige gevallen ook voor de dames der hoogwaardigheidsbekleeders.

In 1554 werd een verbod uitgevaardigd, dat personen, die in het moederland gehuwd zijn, zich zonder hunne vrouwen naar de koloniën begeven. Daar aangetroffen, moesten zij dadelijk teruggezonden worden om met hunne vrouwen samen te wonen. Dit voorschrift is herhaaldelijk vernieuwd. In 1595 en ook later, het laatst in 1628 , werd een afzonderlijk rechterlijk ambtenaar belast met de verwijdering van dergelijke personen.

Slechts bij hooge uitzondering kon aan gehuwden verlof worden verleend om zonder hunne vrouw het land te verlaten.

In 1619 werd zelfs bepaald, dat in de Casa de Contratación te Sevilla zekerheid moest worden gesteld voor de tijdige terugkeer, en dat bij overtreding gevangenisstraf toepassing zou vinden en de overtreder als gevangene de terugreis zou maken. Ook voor het tijdelijk achterlaten van vrouw en kinderen in de Indias hadden de mannen verlof noodig. Het schijnt wel eens voorgekomen te zijn, dat mannen zich beriepen op den dood hunner vrouw, om in hunne beweging vrij te blijven. Nog in 1626 gaf Filips IV met het oog hierop strenge bevelen.

Tusschen 1568 en 1628 vindt men onderscheidene bepalingen tot tegengang van het vagabondeeren van Spanjaarden en hunne afstammelingen ten laste van inboorlingen. Behalve de bestraffing, konden de overtreders gedwongen worden om zich eene broodwinning te kiezen. Voldeden zij niet hieraan, dan werden zij verbannen of naar bepaalde oorden gezonden.

Het toelaten van zigeuners (gitanos) en Mooren in de Indias was verboden. Werden zij er aangetroffen, dan moesten zij met het eerstvertrekkend schip naar Spanje worden gezonden.

\section{$\S 2$. Personen van gemengd bloed (Mestizos).}

Bijzondere maatregelen werden reeds in 1533 en 1569 voorgeschreven voor de onverzorgde kinderen van Spaansche ouders en voor die van gemengd bloed (mestizos). Voor hun persoon en goed werden voogden aangesteld, die, zoodra de leeftijd dit toeliet, er werk van moesten maken, dat de jongens in eenig ambacht of landbouwbedrijf werden ingewijd, dan wel onder de hoede kwamen van een der landheeren (encomenderos) ${ }^{1}$, terwijl

1 Zie hoofdstuk XIV. 
voor de meisjes een werkkring gezocht behoorde te worden bij te goeder naam bekende families. Vóór het bereiken van bedoelden leeftijd moesten de jongens scholen bezoeken en de meisjes met hetzelfde doel in geschikte instellingen worden ondergebracht.

Wettiging van buiten huwelijk geboren kinderen mocht sedert 1625 alleen verleend worden door den Koning met medewerking van den Raad van Indië.

\section{§ 3. Mulatten, negers en kinderen.}

Vele slaven en slavinnen, negers en negerinnen, alsmede mulatten van elders gekomen dan wel in de Indias geboren, hadden hunne vrijheid verkregen en leefden van hun handenarbeid. Het werd billijk geacht hen eene kleine belasting te laten betalen van 1 marco ${ }^{1}$ zilver 's jaars. De inning was dikwijls moeilijk, omdat de belastingschuldigen niet dadelijk te vinden waren. Vandaar het voorschrift, dat zij bij bekende personen moesten inwonen; dezen waren dan verantwoordelijk voor de belasting, en konden deze van het loon inhouden. Werkten zij niet uit eigen beweging, dan werden zij in de mijnen te werk gesteld (1602).

Negers moesten zooveel mogelijk met negerinnen huwen. De uit slavinnen geboren kinderen van Spanjaarden volgden den staat der moeder. Werden die kinderen verkocht, dan had de vader de voorkeur (1563). Negers en negerinnen mochten, al waren zij vrij, geen inboorlingen in hun dienst hebben. Bij overtreding kregen zij 100 zweepslagen, en bij recidive volgde verbanning of zwaardere straf.

Slaven en kleurlingen (ook als "morenos" aangeduid) mochten geen wapens dragen, evenmin gouden voorwerpen, parels en zijde.

Op het wegloopen van slaven waren strenge straffen bedreigd af hankelijk van den duur der afwezigheid. Het was echter verboden om de geslachtsdeelen af te snijden (1540). $\mathrm{Zij}$, die deel namen aan het weder opvatten, kregen groote belooningen. $\mathrm{Nu}$ eens werd bepaald, dat het vrijwillig terugkeeren straffeloosheid medebracht, dan weer dat toch de bedreigde straffen moesten worden opgelegd.

1 De waarde van den marco bedroeg ongeveer 3 reales ( $437 \frac{1}{2}$ cent). Aanrankelijk was de marco uit Hamburg ingevoerd als ío van een dob]ón de oro.

Dl. 79. 


\section{Slavernij.}

Aanvoer van negerslaven zonder voorafgaand verlof was strafbaar, zelfs met verbeurdverklaring van het schip waarop de aanvoer geschiedde. Vervoer van slaven tusschen sommige koloniën was zelfs in het geheel niet toegelaten dan wanneer het een enkelen betrof voor persoonlijk dienstbetoon.

Een vroeger voorschrift van 1571 strekte tot registreering van het aantal negerslaven die van Cabo Verde of elders naar de koloniën werden gebracht.

Het begrip "slavernij» werd in 1609 scherper omschreven door de bepaling, dat inboorlingen niet door Spanjaarden onderling mochten worden uitgeleverd, noch door verkoop, schenking, betaling, of eenige andere overeenkomst, noch ook bij testamentaire beschikking van den een op den ander mochten overgaan. Ook bij de overdracht van werkplaatsen, mijnen, gronden, enz. was dit verboden. De nietigverklaring van ter zake opgemaakte geschriften ging gepaard met zware straffen.

Ook in de Filipijnen was reeds in 1574 slavernij verboden en in elke afdeeling een ambtenaar aangesteld om hiertegen te waken. Uitzondering werd echter gemaakt, ook later nog in 1620 , ten opzichte van de inboorlingen van Mindanao, die Mohammedanen waren geworden en als zoodanig tegen de Spanjaarden strijd voerden. Bleven zij heidenen, dan mochten zij niet tot slaven gemaakt worden.

Het tot slavernij brengen was ook toegestaan ten aanzien van de inboorlingen der eilanden in de Caraibische zee, die zich gewapenderhand tegen het Spaansche gezag verzetten en menschenvleesch aten (1569). Hetzelfde zou hebben gegolden van de bevolking van Chili (1608 en later), die aanvankelijk tot het Christendom overgegaan, later afvallig werd en tegen de Spanjaarden in opstand kwam, ware het niet dat politieke redenen aanleiding gaven om na eenigen tijd algemeene amnestie toe te passen en te gelasten, dat alle slaven en slavinnen in vrijheid zouden worden teruggevoerd naar hunne vroegere woonplaatsen. In 1679 werden opnieuw uitgebreide voorschriften gegeven ten aanzien van het toekennen van volledige vrijheid aan de bevolking van Chili, toen ook uitgestrekt tot die van Peru en Mexico. De vroeger weggevoerden moesten over de verschillende en- 
comiendas ${ }^{1}$ worden verdeeld, terwijl zoo noodig nieuwe encomiendas waren te vormen.

Bleken sommigen tot het heidendom terug te vallen, dan behoorden $z \mathrm{ij}$ in een aangewezen plaats te worden samengebracht.

Het was weleens gebeurd, dat inheemsche vrouwen en meisjes ontvoerd werden. Dit werd in 1541 verboden. Reeds vroeger, in 1526, was een dergelijk verbod uitgevaardigd, en wel in algemeenen zin, ook mannen betreffend. In verband hiermede was zelfs in oorlogstijd het tot slaaf maken van inboorlingen met algeheel verlies van bezittingen straf baar. In het bijzonder gold deze bepaling voor de landheeren ten opzichte van hunne opgezetenen, en voor de eigen hoofden. De bescherming strekte zich ook uit tot inboorlingen afkomstig van Brazilië en ander Portugeesch gebied. De rechters die in gebreke bleven ter zake met kracht op te treden, verloren hun ambt en beliepen eene boete van 100.000 maravedis.

In 1628 bleken redenen aanwezig om op te treden tegen hen, die uit Rio de la Plata en Paraguay inboorlingen wegvoerden naar Brazilië. Te voren, in 1618, was zes jaren galeistraf bedreigd tegen gelijksoortige handelingen.

\section{$\mathrm{XV}$. Inboorlingen, ${ }^{2}$}

\section{$\S 1$. Bescherming.}

$\mathrm{Na}$ hetgeen in de Inleiding is vermeld, zal het niet verwonderen, dat een der boeken (het zesde) bijna geheel aan de inboorlingen gewijd is, en dat Filips II zich in 1580 in dezen zin uit, dat de onderkoningen en andere hooge autoriteiten zich hun lot zullen aantrekken en verbeteren, de nadeelen die zij ondervinden herstellende, opdat zij rustig kunnen leven. De wetten die hiertoe strekken, moesten met groote nauwgezetheid worden nagekomen, en de overtreders met strengheid gestraft. Ook aan de hooge geestelijkheid richt de Koning het verzoek om hunne vaderlijke bescherming uit te strekken tot de inboorlingen als nieuwe belijders van het Christendom. Het was mede de taak der Spaansche landheeren ("encomenderos») ${ }^{3}$ om in

1 Zie hoofdstuk XVI.

2 Men vergelijke hierbij hoofdstuk XXXI $\S 1$ en $\S 6$.

3 Zie hoofdstuk XVI. 
deze richting werkzaam te zijn, in het bijzonder er voor zorgende, dat de bekeerde inboorlingen hun grondbezit niet verloren.

Ten behoeve van inboorlingen bestonden inspecteurs, die hadden na te gaan of de voorschriften betreffende de goede behandeling werden nagekomen, ook van ambtelijke zijde. Zij werden als "protectores y defensores» aangeduid.

Wanneer zij het eerst zijn aangesteld blijkt niet; wèl, dat zij na afgeschaft te zijn, in 1589 op nieuw voorkwamen.

De keuze geschiedde door de onderkoningen en andere hoogwaardigheidsbekleeders. Te letten viel op eenigszins gevorderden leeftijd en geschiktheid om met toepassing van christelijke beginselen en nauwgezetheid te handelen volgens te verstrekken instructies. In 1591 en 1614 werd bepaald, dat zij ook moesten optreden als raadslieden in rechten. Voor deze verrichtingen was verschuldigd een hoofdelijke omslag van $\frac{1}{2}$ reaal. De protectores mochten niet hun taak aan anderen overdragen en waren onafzetbaar zoolang zij hun plicht behoorlijk vervulden. Mestiezen waren niet benoembaar (1578). In 1593 werd ook in de Filipijnen de benoeming van bezoldigde protectores ingevoerd, zonder dat hiermede de opdracht aan de bisschoppen ophield. Daar en elders moesten de onderkoningen en bestuursambtenaren voor de protectores gemakkelijk toegankelijk zijn. Deze laatsten hadden van al hunne verrichtingen rapport uit te brengen aan de onderkoningen ter doorzending aan den Fiskaal van den Raad van Indië, met hunne beschouwingen ter zake.

Bij gedingen tusschen inboorlingen, werd de eene partij bijgestaan door den Fiskaal en de andere door den protector.

De geestelijken hadden telkens aan de protectores bericht te zenden, wanneer zij bemerkten dat inboorlingen in eenig opzicht slecht behandeld werden.

Spanjaarden, negers, mulatten en mestiezen mochten niet in de inlandsche vestigingen wonen, daar de inboorlingen allerlei slechte gewoonten van hen overnamen. Later, en ook in 1646, werd dit herhaald onder bijvoeging, dat het verbod gold, zelfs indien zij daartoe gronden hadden aangekocht. Alleen de mestiezen en zambaigos (kinderen van een negervader en eene indiaansche moeder) in eene inlandsche vestiging geboren, mochten bij de ouders blijven.

De verblijfduur in inlandsche vestigingen van personen, die 
daar niet mochten wonen, was op hoogstens drie dagen bepaald. Het was verboden in inlandsche woningen te overnachten of te stallen, indien in de nabijheid logeergelegenheden bestonden. Zoo niet, dan moest in elk geval voor alles behoorlijk betaald worden, met vermijding van dwang en opvordering van goederen. Op overtreding waren geldboeten bedreigd.

In de nabijheid van mijnen vooral werd de vestiging van inboorlingen in dorpen wenschelijk geacht met hospitalen en al hetgeen verder noodig was voor een tevreden en gezond leven. Zoo veel mogelijk moest ook getracht worden om door goede behandeling verloop van volk en het aannemen van werkkrachten uit andere streken te vermijden. Was dit in eenig geval niet te ontgaan, dan behoorde het te geschieden van zoo nabij mogelijk en tegen behoorlijke betaling (1601).

De plaatsen van vestiging "pueblos y reducciones" mochten niet veranderd worden zonder verlof van den Koning, den onderkoning of den rechter. Was hiervoor onteigening van gronden, waterleidingen en bosschen noodig, die aan Spanjaarden toebehooren, dan moesten dezen worden schadeloos gesteld.

\section{§ 2. Huwelijk.}

Reeds in 1514 werd de vrijheid van mannen en vrouwen erkend om in het huwelijk te treden met wie zij willen, zelfs met Spanjaarden, geboren in het moederland of in de koloniën. Deze erkenning wordt in 1556 herhaald. In 1581 komt het verbod om jonge meisjes in het huwelijk te doen treden voordat de puberteit is ingetreden. Inboorlingen, die tot het Christendom waren overgegaan, mochten niet een tweede huwelijk sluiten voordat het eerste is ontbonden. Later werd het verbod algemeen gemaakt. Filips IV verbood in 1628 de ouders om hunne dochters tot een huwelijk te dwingen door haar tegen geld, goederen of dienstverrichtingen af te staan, zooals het gebruik was. De vrouwen werden daardoor als slavinnen beschouwd in strijd met het karakter van het huwelijk. Eene straf van 50 zweepslagen was bij overtreding bedreigd, terwijl hooger geplaatsten bovendien afdaalden tot "mazegual»(?) De gehuwde vrouw moest den man volgen naar zijne woonplaats en daar blijven totdat zij weduwe werd. Inheemsche vrouwen, met Spanjaarden gehuwd, mochten den man en de uit hun huwelijk geboren kinderen naar het moederland en naar andere koloniën 
vergezellen na dienaangaande voor het hoofd van bestuur der woonplaats eene verklaring te hebben afgelegd (1524). De kinderen uit huwelijken volgden den staat des vaders. De buiten huwelijk geborenen dien der moeder, ook wanneer zij mochten beweren dat de vader een Spanjaard is.

Inboorlingen mochten naar eigen opvatting hunne kinderen bestemmen voor een bepaalden werkkring, zoolang dezen niet belastingplichtig (meerderjarig) waren.

\section{§3. Verplaatsing.}

Vertrek van de eene plaats naar de andere stond aanvankelijk vrij, tenzij hierdoor de «encomenderos" (Spaansche landheeren) ${ }^{1}$ benadeeld werden. Later werd dergelijk vertrek bedreigd met 20 zweepslagen, terwijl de $\mathrm{Cacique}$, die in het vertrek had toegestemd, 4 pesos aan de kerk moest opbrengen. Alleen bij wijze van uitzondering mochten de bestuursambtenaren wijziging van woonplaats toestaan, bijv. aan kinderen, die hunne ouders hadden verloren. Misbruik van bevoegdheid werd gestraft met drie jaren schorsing en geldboete van 500 ducaten voor de schatkist en vrome werken.

Overbrenging van inboorlingen van een warm naar een koud klimaat of omgekeerd was verboden, al bevonden die klimaten zich in hetzelfde gewest. In de Filipijnen was het tegen den wil overbrengen van het eene eiland naar het andere verboden, behoudens het geval van groote noodzakelijkheid, en dan tegen betaling voor het te verrichten werk en met goede behandeling (1574).

Het overbrengen van inboorlingen, mannen of vrouwen, naar het moederland was onvoorwaardelijk verboden, al geschiedde dit met eigen toestemming dan wel met goedvinden van de bestuurders. Overtredingen waren strafbaar met geldboete van 100.000 maravedis, te verdeelen tusschen de schatkist, den veroordeelenden rechter en den aanbrenger, alsmede onherroepelijke verbanning uit de koloniën. De kosten van het vervoer terug kwam voor rekening van de overtreders. Hadden dezen geen middelen, dan werden hun in het openbaar 100 zweepslagen toegediend. Onderkoningen en andere hoogwaardigheidsbekleeders, die in strijd met dit verbod handelden, verloren hun ambt (1528, 1543 en 1556). Het onderhoud van

\footnotetext{
1 Zie hoofdstuk XVI,
} 
in het moederland aangetroffen inboorlingen en hun terugvoer werden bekostigd door den Staat, indien zij uit eigen beweging waren overgekomen.

\section{§ 4. Onderwijs.}

Inboorlingen, die dit wenschten, konden kosteloos onderwijs ontvangen in de Spaansche taal. Dit onderwijs werd gegeven door de kosters, die ook in de dorpen van het moederland les gaven in lezen en schrijven alsmede in de Christelijke leer (1550).

Zooveel mogelijk moesten de inboorlingen een eigen gemeenschap vormen. ${ }^{1}$ Dit behoorde door overreding en zonder dwang te geschieden (1558). Op dezelfde wijze diende gehandeld te worden om de tot het Christendom bekeerden binnen vijf jaren aan het werk te krijgen en aan geregeld bestuur te gewennen (1618). Gelijktijdig werd een vroeger besluit van 1552 hernieuwd, waarbij gelast wordt dat de inboorlingen behoorlijk gekleed moeten gaan, en ieder zich met ijver wijden moet aan zijne bezigheden. Hiertoe dient hun de noodige tijd gelaten te worden (1609).

\section{§ 5. Veeteelt en handel.}

De inboorlingen moesten vrijheid hebben om veeteelt en handel te drijven, zoowel op hunne eigen markten, als met Spanjaarden. Deze laatsten mogen tot bevordering van den handel niet het verkoopen van landbouwproducten of andere goederen bemoeilijken. Aanleiding tot dit voorschrift was, dat wel eens geweldpleging plaats had van de zijde der Europeesche koopers. Met hetzelfde doel was ook verboden het met opzichters deelen in de winst van den arbeid der inboorlingen.

In het belang van de veefokkerij was uit het moederland overgenomen eene instelling, met den naam "mesta" aangeduid, zijnde een vereeniging der voornaamste veehandelaren, die in afdeelingen geregeld bijeenkomsten hielden, waarbij de eigenaren van 300 of meer stukken vee de leiding hadden. De vereeniging was bevoegd bindende regelingen te maken betreffende het vee, en bij overtreding vastgestelde straffen toe te passen. Het hoofd der vereeniging voerde den titel van ‘ alcalde».

De bouwlanden der inboorlingen mochten niet voor weideplaatsen dienen.

1 Men raadplege hierbij hoofdstuk XXVIII. 
De veeverblijven mochten zich niet bevinden binnen $1 \frac{1}{2}$ mijl dan wel $\frac{1}{2}$ mijl, al naarmate het groot vee, dan wel klein vee betreft, van de oude vestigingen, en twee malen zooveel van de nieuwe vestigingen, op straffe van verbeurte van de verblijfplaatsen en van de helft der daarin aanwezige beesten. Overigens hadden de inboorlingen het recht om vee te dooden dat op hun land kwam.

\section{§ 6. Boschbourv.}

De aankap in de bosschen geschiedde volgens aangegeven regels. Waardevolle boomen mochten alleen voor 's lands dienst worden geveld. Daarentegen stond het den inboorlingen vrij op de bergen te kappen wat zij noodig hadden, met enkele plaatselijke uitzonderingen. Herbossching moest geregeld geschieden. Zekere roode houtsoort, brasil genaamd, mocht in het moederland alleen uit de koloniën worden ingevoerd.

\section{§ 7. Beschikking bij doode.}

De beschikking bij doode stond in de volste mate vrij. Het was allen, ook geestelijken, verboden hierop inbreuk te maken ten behoeve van de kerk, met opdracht aan de ambtenaren en de prelaten om hiertegen te waken (1580).

\section{§ 8. Wapens.}

Het verkoopen of anderszins verstrekken van wapens aan de inboorlingen was met geldboete van 10.000 maravedis bedreigd, en bij herhaling met het verlies der helft van alle bezittingen; zelfs kon lijfstraf worden toegepast. De wapens werden bovendien verbeurd verklaard. Alleen aan zeer voorname inboorlingen mocht door den landvoogd of andere autoriteit het bezit van eenig wapen worden toegestaan (1501 e. v.).

\section{§ 9. Paardrijden.}

Het verbod in 1568 afgekondigd om paard te rijden, werd in 1633 ingetrokken.

$\S 10$. Bevoegdheden in verband met godsdienst.

Het was aan de Inquisitie verboden tegen inboorlingen op te treden. Toch kon het noodig zijn ter zake van den godsdienst maatregelen te nemen. Dit was dan opgedragen aan de geestelijkheid, terwijl zij, die door toovermiddelen misdrijf plegen (h e chiceros), voor den gewonen rechter betrokken werden (1575). 


\section{§ 11. Wijn en bedwelmende dranken ${ }^{1}$.}

Wijn mocht niet aan inboorlingen worden verkocht. Strenge maatregelen waren ook voorgeschreven tegen het gebruik van de mengsels van de mague $\mathrm{y}^{2}$, vooral van een drank aangeduid met den naam 'pulque", die aan lichaam en geest door bedwelmende eigenschappen veel nadeel toebracht en tot het plegen van strafbare handelingen en onzedelijke, heidensche gebruiken prikkelde.

In 1671 werd in Mexico het gebruik van de mengsels wettelijk geregeld ten bate van de schatkist, met dien verstande dat het aantal plaatsen waar het gebruik veroorloofd was (pulquerías) beperkt bleef tot 36 , waarvan 24 voor mannen en 12 voor vrouwen.

\section{§ 12. Dansen en feesten.}

Openbare dansen en feesten waren alleen met toestemming van het bestuur veroorloofd, en dan niet tijdens den oogst en met inachtneming van drankmatigheid.

\section{§13. Bijzondere rechten.}

Aan de inboorlingen van Tlaxcala (Mexico), die het eerst het Christendom hadden aanvaard, werden in 1545 voorrechten toegekend; o. a. mochten zij als bestuurshoofden (gobernadores) eigen landslieden hebben, en zich onmiddellijk tot den Koning wenden, indien zij over iets te klagen hadden, terwijl het verboden was hun dienstverrichtingen op te leggen in andere landstreken.

Ook aan de bewoners van Guazalco werden bijzondere rechten toegekend.

$\mathrm{Zij}$, die eischende of verwerende in rechten wilden optreden, konden dit doen zonder betaling van eenige belasting. De inheemsche gemeenten en de hoofden hadden slechts de helft te voldoen van hetgeen in het moederland te betalen zou zijn. Rechters en administratieve autoriteiten hadden hierop streng te letten.

\footnotetext{
1 Men vergelijke hierbij de bepalingen over coca en a ñ in hoofdstuk XVII $\$ 4$.

3 Met maguey wordt aanyeduid de aloë-plant, waaruit een sap bereid werd, dat op zichzelf geen kwaad deed.
} 


\section{$\S 14$. Toezicht van oudsten (caciques).}

Het toezicht over de inboorlingen in de plaatsen waar zij gevestigd zijn, was opgedragen aan oudsten ("c a ciques»), die op hunne beurt onderworpen waren aan het gezag van hoofden die den titel voerden van "alcalde» en van "regidor".

De instelling van oudsten werd aangeduid met het woord "señorío» of "cacicazgo», en de erfelijkheid hiervan van vader op zoon erkend. Ontheffing was zelfs in geval van misdrijf verboden (1596). De caciques mochten zich echter niet "señores» noemen. Mestiezen waren uitgesloten. De inboorlingen waren gehouden onder hunne eigen caciques te blijven. Dezen mochten hiervan echter geen misbruik maken door het opvorderen van meisjes, en door onrechtmatige inningen, en moesten de te hunnen behoeve verrichte werkzaamheden behoorlijk betalen ter beoordeeling van de bestuurs-ambtenaren. Deze laatsten hadden ook toe te zien, dat o. a. door mijneigenaars geen dwang werd uitgeoefend op de oudsten om werklieden te leveren.

De in sommige streken oudtijds bestaan hebbende gewoonte om bij de begrafenis van oudsten, inboorlingen met dezen te begraven, werd in 1552 met nadruk verboden.

Geen oudste mocht zonder vergunning van den Koning het moederland betreden, zelfs niet met medeweten van den onderkoning.

De oudsten waren met rechtspraak over hunne onderhoorigen belast behalve in ernstige misdrijfzaken, en hadden ook te zorgen voor de verdeeling van de belastingen.

Ook de alcalde en de regidor hadden eenige rechtsmacht. $Z$ ij mochten n.l. 1 dag gevangenis en 6 of 8 zweepslagen opleggen aan hunne dorpsgenooten, die op een feestdag de mis niet bijwoonden, dan wel zich aan dronkenschap of dergelijke handelingen overgaven. De alcalde was eveneens bevoegd om bij afwezen van hoogere autoriteiten tegen de negers en mestiezen op te treden en hen voorloopig gevangen te zetten.

\section{Verdeeling van grond (Repartimiento) en stichting van „encomiendas".}

\section{$\$ 1$. Doel der instelling.}

Deze instelling is wel een der meest in het oog vallende, vooral wegens de misbruiken die zij tengevolge had. $Z_{i j}$ bestond reeds vóór de komst der Spanjaarden, o.a. in Peru onder 
den naam van 'mita», en doet eenigszins denken aan de "particuliere landerijen» op Java, al zijn ze ook in oorsprong anders.

Fernando V bepaalde in 1509, dat zoodra een landstreek onderworpen was aan het Spaansch gezag en zich Spaansche kolonisten kwamen vestigen, aan ieder hunner door den "adelantado, een zeker aantal inboorlingen behoorde te worden toegewezen, voor wier geestelijk en maatschappelijk welzijn zij te zorgen hadden, d.w.z. inwijding in de leerstellingen van het heilig Katholiek geloof, gepaard met bescherming van personen en goed tegen elke aanranding. Deze omschrijving stemt overeen met den aanvang van titel IX in boek 6 waar voormeld doel omschreven wordt als: cel bien espiritual y temporal de los indios, $y$ su doctrina y enseñanza en los articulos y preceptos de nuestra santa fé católica, y que los encomenderos los tuviesen á su cargo y defendiesen á sus personas y haciendas, procurando que no reciban ningún agravio». Wederkeerig waren de toegewezen inboorlingen verplicht diensten te verrichten.

De kolonisten, die dergelijke opdracht verkregen, voerden den naam van "encomenderos», ${ }^{1}$ en hadden een eed af te leggen de hun toevertrouwde bevolking goed te zullen behandelen en zich te houden aan de verschillende plichten.

In de titels, waarbij de encomiendas werden verleend, moesten sedert 1614 verıneld worden: $1^{\circ}$ de waarde daarvan in verband met de gewone opbrengsten, na aftrek van de verplichte uitgaven voor godsdienstonderwijs, geneeskundige hulp, belasting enz.; $2^{\circ}$ het aantal opgezetenen; $3^{\circ}$ het bedrag der verschuldigde belasting. Aan het hoofd der acte was te vermelden op welke wijze en sedert wanneer de encomienda vrij was gekomen.

\section{§ 2. Verplichtingen der encomenderos.}

Met de opdracht van zorg over een deel der bevolking ging gepaard de toewijzing (repartimiento) van een stuk grond, waarop de (encomenderov zich met die bevolking had te vestigen, (vandaar de uitdrukking "encomiendas») terwijl

1 Van het werkwoord encomendar = opdragen. 
hij met beleid had te trachten de bevolking over te halen zich in dorpen te vereenigen en kerken te bouwen. Voldeed hij niet hieraan, dan was hij verplicht aan den Staat in geld uit te keeren wat hij anders had moeten ten koste leggen aan de vervulling van zijn plicht. Bij opzettelijke tekortschieting verloor hij zijne "encomienda" en werd hij tevens verbannen.

Zoo noodig, konden twee of drie landheeren gezamenlijk den bouw van een kerk bekostigen.

De landheeren hadden ook wapens en paarden in voorraad te houden voor de verdediging van het land, meer of minder naar mate de inkomsten die zij genoten. Met geoefende troepen moesten zij te hulp komen, wanneer dit noodig bleek.

$\mathrm{Bij}$ afwezen hadden de landheeren te zorgen voor bekwame gemachtigden (e s c u deros). ${ }^{1}$ Dergelijke gemachtigden moesten ook worden aangesteld door de voogden of curatoren van minderjarige ${ }^{2}$ dan wel onder curateele gestelde landheeren. Op plaatsen, door de bestuursambtenaren aangeduid, moesten binnen twee jaren na de aanvaarding van de "encomienda", steenen huizen verrijzen op kosten van de landheeren.

Waren geen steenen te verkrijgen, dan konden andere materialen (argamasa en tapiería = soorten kalk) worden gebezigd. Bovendien hadden de landheeren een gemeubeld huis te onderhouden in de meest nabijgelegen hoofdstad.

Daarentegen kwam in 1618 - blijkbaar als gevolg van ingeslopen misbruiken - het verbod aan de landheeren om binnen hunne ancomiendas, een huis of buhío ${ }^{3}$ te hebben, al was het ook onder den naam van magazijn, en met de uitgesproken bedoeling om dit bij overlijden of dadelijk aan de inboorlingen te schenken. Het gebouwde werd verbeurd verklaard ten bate van de inboorlingen en van de schatkist. Ook het overnachten in de «encomienda» voor meer dan één nacht was verboden. Dezelfde voorschriften golden voor de echtgenooten, ouders, kinderen, verwanten, dienaren en gasten der landheeren, alsmede in het algemeen voor mestiezen, mulatten, negers en slaven. Bovendien was elke aanraking tusschen negers en opgezetenen verboden, daar de laatsten vele verkeerde gewoonten vản de eersten overnamen.

1 Letterlijk: schildknapen.

- De minderjarigheid liep tot bereiking van den 25 jarigen leeftijd.

3 Algemeene benaming voor verblijfplaatsen van licht materiaal. 
De landheeren mochten ook geen werkplaatsen of veefokkerijen houden in of nabij hun land. Verbodsbepalingen betreffen verder het in huis nemen van vrouwelijke opgezetenen van het land, al geschiedde dit tegen betaling, op straffe van 100 goud-pesos. Ook het zich bemoeien met of het tegengaan van huwelijken onder de opgezetenen, was strafbaar met het verlies van het heerlijk recht.

Bij voorgenomen huwelijken tusschen opgezetenen van hetzelfde land (dan wel uit hetzelfde huis) hadden de geestelijken vooraf na te gaan of de echtgenooten uit volkomen vrijen wil handelden.

Opgezetenen mochten niet verhuurd of in pand gegeven worden op straffe van verlies der cencomiendas en eene geldboete van 50.000 maravedis, noch ook in een ander gewest werkzaam zijn.

De landheeren mochten zich niet uit het gewest van hun land verwijderen zonder verlof van het bestuur. Dit verlof mocht slechts voor korten tijd verleend worden onder verplichting om een plaatsvervanger te stellen. Was hun terugkeer noodzakelijk, en voldeden zij niet binnen vier maanden hieraan, dan verbeurden zij hun recht. De rechter was bevoegd verleende verloven in te trekken. Verlof naar Spanje mocht slechts bij hooge uitzondering worden verleend. Een dezer uitzonderingen was het afhalen van eene in Europa achtergebleven echtgenoote. Voor ongehuwde encomenderos was het plichtmatig binnen drie jaren een huwelijk aan te gaan, behoudens gevorderden leeftijd of eenige andere geldige reden.

De landheeren mochten geen ambten vervullen buiten de plaatsen waar zij verblijf hadden te houden. Sommige ambten waren hun ontzegd.

Aan sommige landheeren met groote encomiendas was de verplichting opgelegd om jaargelden van ten hoogste 2000 pesos op te brengen, bestemd voor verdienstelijke personen die geen encomienda hadden.

Inkomsten van opengevallen encomiendas konden worden aangewend ten bate van behoeftigen en vrome werken.

Indien de encomenderos intendanten (calzirques of mayordomos) wilden aanstellen, hadden zij de voorafgaande goedkeuring noodig van het betrokken bestuurshoofd, en werd zakelijke zekerheidstelling voor eventueele onrechtmatige handelingen vereischt. Er moest n.l. streng gewaakt worden dat 
alleen diegenen gekozen werden, die den inboorlingen een goed hart toedroegen.

\section{§ 3. Erfopvolging.}

Bij het overlijden van een landheer, werd hij krachtens bevel van den landvoogd door den oudsten wettigen zoon opgevolgd met gelijke rechten en verplichtingen als de vader had. Was deze zoon minderjarig, dan kwam het beheer aan een vertegenwoordiger.

Wilde de oudste zoon het land niet aanvaarden, of werd dit verhinderd doordien hij zelf reeds een land had, of om eenige andere reden, dan kwam het land aan den tweeden zoon, en zoo vervolgens. Bestonden er geen zoons, dan was de oudste dochter aan de beurt, dan wel bij weigering of verhindering de tweede dochter, en zoo vervolgens.

Waren er geen kinderen, dan werd de weduwe opvolgster, met dien verstande dat na een tweede huwelijk de nieuwe echtgenoot optrad. In beide gevallen moest het huwelijk minstens zes maanden te voren gesloten zijn. Blijkbaar om een huwelijk ad hoc te vermijden.

Gedurende een aantal jaren gold de bepaling, dat alleen de oudste zoon mocht opvolgen, met de verplichting om zijne broers en zusters te onderhouden, en ook zijne moeder totdat zij hertrouwde. Was de oudste zoon te voren overleden, dan kwam diens zoon of kleinzoon, en indien dezen er niet waren, diens dochter of kleindochter, in het genot van het land. Eerst hierna de tweede zoon van den vroegeren landheer.

Toen later ook een der dochters werd toegelaten tot de opvolging, rustte op haar de plicht binnen het jaar te huwen, indien zij huwbaar was, en anders dadelijk na het intreden van de huwbaarheid. $\mathrm{Zij}$ had overigens ook hare zusters en hare moeder te onderhouden.

Bij een huwelijk tusschen personen, die ieder een land hadden, moest gekozen worden tusschen de twee landen. Was het recht op het gekozen land beperkt tot het leven van de vrouw, en kon het recht op het andere land nog op een later geslacht overgaan, dan eindigde het recht van den man, ook bij vooroverlijden van de vrouw, eerst bij diens dood. Stierf de man vooraf, dan bleef de vrouw in het genot tot haar dood. Waren er kinderen uit het tweede huwelijk van de vrouw, dan kon aan dezen verlenging van het recht worden toegestaan. 
De overgang op een volgend geslacht ging steeds ipso jure, behoudens verwerping binnen 15 dan wel 35 dagen naar mate de afstand der woonplaats. Stierf de opvolger binnen dezen termijn zonder verklaring van aanvaarding of verwerping, dan verviel het recht aan den Staat. Voordat zes maanden na de aanvaarding verloopen waren, had de nieuwe verkrijger te zorgen dat hij van den landvoogd een nieuwen titel verkreeg, op verbeurte van de reeds verkregen vruchten. Afstand van het recht op de vruchten als huwelijksgift ten behoeve van een zoon of dochter, was met toestemming van het bestuur veroorloofd.

In Mexico (Nueva España) mocht het recht gedurende vie r geslachten behouden worden, mits niet later verkregen dan het jaar 1607, ter voorkoming van verarming der nakomelingen van verdienstelijke grondleggers der kolonie. De overgang van het tweede op het derde, en van het derde op het vierde geslacht, geschiedde op dezelfde wijze als van het eerste op het tweede.

Overigens gold het recht slechts voor twe e geslachten (voor twee «levens»). Daarna openvallende encomiendas werden docr de onderkoningen toegewezen aan Spanjaarden, die zich verdienstelijk hadden gemaakt; ook nog in 1655 .

Bij overlijden van opgezetenen, mochten de landheeren zich niets van de nalatenschappen toeëigenen, al waren er geen erfgenamen. In dit laatste geval, kwamen de nalatenschappen aan het inheemsche gemeenschapsverband waartoe de overledenen behoorden, voor zooveel noodig om verschuldigde belastingen te betalen, en anders aan de koninklijke schatkist (patrimonio real).

\section{$\S 4$. Beperkingen.}

Onderkoningen, geestelijken, geestelijke instellingen, ambtenaren en vreemdelingen mochten reeds in 1530 geen encomenderos zijn. Later werden uitzonderingen gemaakt voor enkele categoriën van ambtenaren.

Bij vertrek naar het moederland van Spanjaarden mochten zij hunne rechten noch door schenking of verkoop, noch op eenigerlei andere wijze aan anderen overdragen. Door het vertrek verviel hun recht, en mocht hierover ten behoeve van een nieuwen encomendero worden beschikt door den onderkoning.

Niemand mocht encomendero zijn over twee stukken 
grond; wèl mocht in bijzondere gevallen een stuk vergroot worden. Het eigenmachtig verdeelen van een cencomienda) onder verschillende personen, met vaststelling voor elk deel van de daartoe behoorende bevolking, was in geen enkel geval veroorloofd. Overtreding was bedreigd met onherroepelijk verlies van recht, terwijl ook latere verkrijging van een encomienda voor den overtreder uitgesloten was.

Sedert 1618 was de wetgever er op uit de encomiendas zoodanig te beperken, dat niet meer dan een bepaald aantal opgezetenen daarop aanwezig mocht zijn, en wel afwisselend van 30 tot 12 .

In 1625 werd bepaald, dat alleen door tusschenkomst van den Raad van Indië nieuwe encomiendas mochten worden verleend.

Opgezetenen van de eene encomienda mochten niet te werk gesteld worden in eene andere noch door de encomenderos, noch op staatsgezag.

Elke encomienda was sedert $1627 \frac{1}{3}$ van de inkomsten in natura aan de schatkist verschuldigd.

Tusschen 1608 en 1622 , en ook later tot 1646 , werden de encomiendas aan herziening onderworpen, en het verkrijgen van nieuwe titels door tusschenkomst van den Raad van Indië verplicht gesteld.

\section{§5. Verplichtingen der opgezetenen.}

Over de soort diensten der opgezetenen aan den encomendero verschuldigd, vindt men aanvankelijk geen voorschriften. Aan het ingeslopen misbruik om telkens andere opdrachten te geven, trachtte de wetgever een einde te maken door den last tot het vooraf vaststellen van soort en maat van het te verrichten werk, terwijl tevens verboden werd het doen samenwerken van vrouwen in aangewezen huizen, waar zij weleens lastig gevallen werden. Veel schijnt dit niet gebaat te hebben, want in 1612 wordt in korte en duidelijke woorden afgekondigd, dat diensten ten behoeve der landheeren niet meer mogen worden gevorderd. Het vermoeden schijnt gerechtvaardigd, dat opzettelijk in den aanvang alles op losse schroeven was gelaten, en dat als gevolg hiervan vergaande misbruiken ontstonden, die ten slotte tot een algemeen verbod voerden. De kracht hiervan zal wel niet heel sterk zijn geweest, want in 1633 volgde een hernieuwd verbod van Filips IV. 
Uit een volgend hoofdstuk zal trouwens blijken, dat het begrip diensten, ook overigens, zeer onbestemd was.

Behalve de persoonlijke diensten, waren ook belastingen verschuldigd zoowel aan den Staat als aan de encomenderos. Deze belastingen konden worden opgebracht in geld dan wel in landbouwproducten (graan, maïs, tapioca, specerijen, vruchten, groenten, enz.) en verder in kippen, visch, katoen en kleedingstukken, waartoe bijzondere aanslagen moesten plaats hebben, waaraan ook de encomenderos gebonden waren; ook in goud en zilver, dat vooraf gemerkt moest worden nadat de waarde was vastgesteld.

Het deel der belasting voor de kerken bestemd, moest afzonderlijk beheerd worden.

Het verschuldigde moest in het eigen dorp worden geïnd. Het elders betalen of inleveren was verboden, evenals het leveren van maïs ten behoeve van hoogwaardigheidsbekleeders, zooals vroeger gebruikelijk was (1631).

In geval van zware ziekten was ontheffing dan wel vermindering van belasting voorgeschreven. Hierop mocht later niet worden teruggekomen.

Behoudens bijzondere voorvallen was de aanslag voor drie jaren geldig.

\section{Persoonlijke diensten en mijnarbeid.}

\section{$\S 1$. Vrijwillige en gedwongen diensten.}

Op dit gebied heerscht veel onzekerheid en verwarring. Blijkbaar waren de diensten, in den aanvang van de inboorlingen geëischt, zeer zwaar ${ }^{1}$, en bleek het noodzakelijk hierin beperking te brengen. De indruk dien de lezing der onderscheidene voorschriften geven is echter, dat de machthebbenden niet op afdoende wijze ingrepen, doch in veelheid van woorden een kracht trachtten te leggen, die de lezers er moeilijk in konden vinden. $\mathrm{Er}$ is ook voortdurend dooreenmenging van vrijwillige diensten ten behoeve van particulieren, waaromtrent bepaald

1 De verplichting der inheemsche bevolking in sommige gebiedsdeelen onder haar eigen hoofden vóór de komst der Spanjaarden om gemeenschappelijk aangewezen stukken grond te bewerken, met boomen te beplanten en ander werk te verrichten ten algemeenen nutte, werd aangeduid met het woord milpa.

DI. 79. 
wordt dat zij behoorlijk betaald moeten worden, met inbegrip van den tijd van heen en weer gaan, en het verbod aan particulieren om diensten en leveringen te vorderen. Dan komen er weder enkele gevallen waarin het vorderen van diensten wordt toegestaan tegen vastgestelde betaling, bijv. het vervoer van aangewezen landsdienaren in draagstoelen. Vervolgens is ook weer sprake van diensten waarbij het openbaar belang min of meer betrokken is, zooals o. $\mathrm{m}$. voor de ontginning van mijnen, waartoe inboorlingen van overheidswege werden aangewezen, en waarbij groote beperking en voorkoming van misbruik op den voorgrond stonden.

In 1609 vindt men voorschriften voor de Filipijnen, welker hoofdbeginselen zijn, dat alleen dan diensten gevorderd mogen worden, wanneer de omstandigheden dit noodzakelijk maken, hetgeen dan geschieden moet tegen betaling en met inachtneming van voorwaarden door het bestuur vast te stellen in het belang der gezondheid.

De andere diensten, in het algemeen belang ten behoeve van wijnbouw, olieproductie, parelvisscherij, logeergelegenheden, wegen, veeteelt, werkplaatsen enz., mogen alleen gevorderd worden in de gevallen uitdrukkelijk toegestaan (1609).

In het algemeen blijven de inboorlingen vrij voor deze diensten dag- of weekbetaling te eischen. Overschrijden zij hierbij echter redelijke grenzen, dan wordt het verschuldigde vastgesteld door de overheid. Betaling in wijn, honig, enz. was verboden. Ten aanzien van de diensten voor de logeergelegenheden en wegen moest de grootst mogelijke beperking in acht worden genomen. Voor de bediening in de logeergelegenheden (pasangrahans zou men in Indië zeggen) mochten geen vrouwen gebezigd worden, dan vergezeld van hare mannen, vaders of broeders. De verplichting in de logeergelegenheden bestond hierin, dat aan de gasten brood, wijn en vleesch verstrekt werd en aan hunne trekdieren maïs; alles tegen betaling.

De diensten voor wijnbouw en olieproductie golden niet altijd als te bezwarend voor de inboorlingen.

Het werken in fabrieken en werkplaatsen van linnen, wol, zijde, katoen, suiker ${ }^{1}$ en andere voortbrengselen was sedert 1595 overal verboden - zelfs bij wijze van straf - ook al werd het

1 Later werd den mannen toegestaan in de suikerriettuinen bij het snijden en vervoeren behulpzaam te zijn. 
bedrijf door Spanjaarden gezamenlijk met inboorlingen gedreven. De fabrikanten mochten beschikken over negers of ander werkvolk, maar niet over inboorlingen, zelfs niet wanneer dezen zich vrijwillig aanmeldden. Het was overigens verboden om te trachten hen hiertoe over te halen door tusschenkomst van hunne hoofden (caciques) of op welke andere wijze ook. Alleen in werkplaatsen, die uitsluitend door inboorlingen gedreven werden, zonder medewerking op eenigerlei wijze van Spanjaarden, mochten zij elkander over en weder bijstaan.

Zware geldboeten en andere straffen waren tegen overtredingen bedreigd. Ook de ambtenaren, die overtredingen door de vingers zien, zijn strafbaar, evenals de rechters, die de voorschriften niet streng toepassen.

\section{\$2. Diensten van vrouwen en minderjarigen.}

Vrouwen en minderjarige kinderen waren niet tot gedwongen arbeid verplicht (1609). De laatsten mochten met toestemming van hunne ouders veehoeders zijn, en ontvingen dan als wekelijksch loon $2 \frac{1}{2}$ reaal benevens voeding en kleeding. $\mathrm{Zij}$ konden ook met vrijen wil leerjongens worden in fabrieken.

In het algemeen was taakwerk toegestaan, maar de werklieden mochten zich niet voor langer dan één jaar verbinden.

Vrouwen mochten zich niet verhuren voor werk in huizen van Spanjaarden, tenzij de man in hetzelfde huis werkzaam was. Ongehuwde meisjes evenmin zonder toestemming van hare ouders, en alleen indien zij in haar eigen vestiging bleven. Huwde een meisje terwijl haar dienstverband nog liep, dan mocht zij blijven waar zij was, maar aan haar man moest worden toegestaan te slapen in het huis waar zij diende.

Inboorlingen, belast met de bewaring van huis en goed van Spanjaarden, waren niet verantwoordelijk voor diefstal, indien deze geschiedde buiten hunne schuld of onachtzaamheid. Dit gold ook voor veehoeders.

Dienstboden mochten niet gedurende hun diensttijd aan anderen worden afgestaan.

\section{§ 3. Land-en mijnbouzvdiensten.}

$\mathrm{Zij}$, die gedwongen of vrijwillig werkzaam waren bij den landbouw, dan wel in mijnen, moesten gelegenheid hebben om in eigen huis of elders naar eigen verkiezing te slapen. In elk 
geval moest gezorgd worden voor behoorlijk nachtverblijf. Bij ziekte was verpleging voorgeschreven. Het doen hooren van de mis en het bevorderen van een christelijken levenswandel eveneens. Dit gold mede voor dienstboden.

Het toekennen van een aandeel in de opbrengsten aan de mayordomos (opzichters), vroeger toegestaan, werd in 1609 verboden.

\section{§4. Diensten bij de teelt van coca en añir.}

Bijzondere bepalingen golden voor de diensten bij de teelt van coca en añir ${ }^{1}$ in Peru.

In 1569 overwoog Filips II eensdeels, dat de inboorlingen van de coca misbruik maakten bij hunnen afgodendienst en hieruit voortvloeiende toovenarij en bijgeloof, meenende dat het inslikken van coca hunne lichaamskracht bij het werk verhoogde, wat slechts een inblazing van den duivel was; anderdeels, dat velen ziek werden en stierven, omdat in de streken voor den aanplant geschikt, hitte en vocht heerschten. $\mathrm{Hij}$ beval daarom groote zorg voor de gezondheid, en droeg aan de geestelijkheid op om met kracht de verderfelijke opvattingen te bestrijden: Vier jaren later kwam eene uitvoerige regeling ter zake, waaruit o.a. blijkt dat de coca veel gebruikt werd door de arbeiders in de zilvermijnen, blijkbaar met dezelfde bedoeling als opium. De taak der arbeiders op de coca-aanplantingen werd vastgesteld. Zoo ook de contractsduur (hoogstens voor één oogst- en afwerkingstijd), de verblijfplaatsen, de kleeding, de voeding, de geneeskundige behandeling en ziekenverzorging, het loon, de coca-verkoop, de zorg voor de vrouwen, het hooren van de mis; alles met boetebedreiging bij overtreding.

In 1563 was reeds voor Guatemala bepaald, dat bij den aanplant van añir geen inboorlingen mochten worden gebezigd dan met eigen goedvinden.

\section{§5. Mijnarbeid. ${ }^{2}$}

Titel XV behandelt den mijnarbeid. Veel van de juist medegedeelde voorschriften vindt men hier terug. Tevens blijkt,

1 Planten met verdoovende kracht. De cocabladeren werden o.a. bestreken met de asch van cheropodium quinoa en door de inboorlingen gekauwd evenals de sirih in Indië. Men vergelijke hierbij $\S 1 \mathrm{t}$ in hoofdstuk XV bl. 121.

2 Men vergelijke hierbij hoofdstuk XXV. 
dat het werken in de mijnen, die de winning van goud, zilver en kwikzilver beoogden, ten deele verplicht was, doch steeds tegen betaling geschiedde. Het recht op toewijzing van inboorlingen voor den mijnarbeid was afgebakend, zoowel wat betreft het aantal, als hetgeen van hen geëischt mocht worden. In het bijzonder mocht op de arbeiders niet worden verhaald het werk van overledenen, gevluchten en afwezigen. In alle opzichten moest rechtvaardigheid op den voorgrond staan, met inachtneming van gegeven voorschriften. $\mathrm{Zij}$, die zonder mijnen te hebben, zich werkvolk lieten toewijzen, werden gestraft met verbeurdverklaring van hunne bezittingen en verbanning. Het toewijzen was overigens niet toegestaan voor weinig opbrengende mijnen, en de arbeiders mochten zich niet afkoopen.

$\mathrm{Bij}$ het einde van elke week moesten de arbeiders hun loon ontvangen, zoowel de toegewezenen als de vrijen. Den Zondag hadden zij vrij, met dien verstande dat voor hun zieleheil gezorgd werd. Ook in de ziekenzorg was voorzien.

Op gevaarlijke plaatsen in de mijnen mochten alleen vrijwilligers werken. Waren dezen niet te verkrijgen, dan konden arbeiders worden aangewezen met gunstiger voorwaarden dan anders gebruikelijk. Het leegpompen der mijnen werd als een zwaar werk beschouwd, waarvoor geen inboorlingen, doch alleen negers en van elders ingevoerden mochten worden gebruikt.

De werktijd, ook van de toegewezenen, werd berekend met inbegrip van het heen en weergaan, hoogstens vijf mijlen daags. In het belang van de niet in de nabijheid wonenden, werden in 1609 voorschriften gegeven betreffende het stichten van nederzettingen met inbegrip van ziekenhuizen.

\section{§6. Beperkingen.}

In 1622 maakte Filips IV voor Chili een einde aan allen gedwongen arbeid, onverschillig op welke wijze het recht hierop verkregen was, met dien verstande, dat de verschuldigde belasting in geld door persoonlijken arbeid gekweten mocht worden.

Het duurde echter niet lang, of men keerde tot het vroegere stelsel terug, al was het ook met meer beperkingen, vooral wat betreft den tijdsduur, welke bepaald werd op 207 dagen 's jaars, d. w. z. 9 maanden van 23 dagen, zoodat drie maanden vrij bleven voor eigen landbouw tusschen de 12 van het jaar in.

Inboorlingen behoorende tot landbouw-ondernemingen hadden 
slechts 160 werkdagen. $\mathrm{Zij}$, die in de steden woonden, gewoonlijk in den krijg gevangen genomen, kregen voor huiswerk van 7 tot 16 pesos 's jaars; voor bijzondere werkzaamheden bepaalde de overheid (de corregidor) het meerdere.

Ook voor de inboorlingen van Tucumán, Paraguay en Rio de la Plata bestonden afzonderlijke voorschriften, alle van 1618 (Filips III), waarvan alleen aandacht trekt het verbod om vrouwen met een eigen zoogend kind als minnen te gebruiken voor Spaansche kinderen.

\section{Bestuur in het moederland : de Koning en de Koninklijke Raad van Indië (Consejo Real de las Indias).}

Het opperbestuur berustte bij den Koning, die hierin bijgestaan werd door den Koninklijken Raad van Indië (Consejo Real de las Indias), in 1542 door Karel I (V) ingesteld.

Aanvankelijk zetelde dit lichaam in de Koninklijke residentie; later werd het overgebracht naar Sevilla, omdat scheepvaart en handel met de overzeesche gewesten in deze stad hun aange. wezen middelpunt hadden. Slechts ten deele ook Cadix met de dicht daarbij gelegen havenplaats Sanlúcar, met uitsluiting van alle andere havens.

\section{$\S 1$. Samenstelling van den Raad van Indï̈.}

De Raad was samengesteld uit een voorzitter, als hoedanig werd aangewezen de Groot-Kanselier (Gran $\mathrm{Chanciller} \mathrm{de}$ las Indias), die als zegelbewaarder des Konings het recht had de uitgaande stukken van het Koninklijk zegel te voorzien; ${ }^{1}$ een afwisselend aantal leden, aanvankelijk acht, een Fiscal en twee secretarissen, alsmede een plaatsvervangend voorzitter. Deze allen moesten zijn: van adel en onberispelijke afkomst, godvreezend, en in kennis en gedrag uitmuntend. Verder waren er drie verslaggevers (relatores) en in het bijzonder voor rechtzaken een griffier (escribano de Cámara de justicia); vier rekenplichtigen met een algemeenen kashouder; en eenige andere ambtenaren, die men in $\S 2$ vermeld vindt. Ook was een

$1 \mathrm{Bij}$ het in ontvangst nemen van het Koninklijk zegel moesten bepaalde eerbewijzen worden gegeven. Het bewaren en verzorgen van het zegel moest ook op eerbiedige wijze geschieden. $\mathrm{Bij}$ het ontvangen van nieuwe zegels werden de oude versmolten ten bate der schatkist. 
kapelaan aangewezen om de mis te bedienen bij het samenkomen van den Raad.

Jaarlijks benoemde de voorzitter een der leden tot inspecteur van het personeel, en een ander tot superintendent der rekenplichtigen.

Allen waren tot geheimhouding verplicht. $\mathrm{Zij}$ mochten geen geschenken, van welken aard ook, aannemen, noch aanberelingen of andere gunsten verleenen. In zaken waarin verwanten betrokken waren, hadden zij zich te onthouden.

\section{§ 2. Werkkring van den Raad van Indië. ${ }^{1}$}

De werkkring van den Raad was: den Koning ter zijde te staan in het behoorlijk bestuur en beheer der koloniën.

Onder Filips III en Filips IV zijn de bevoegdheden van den Raad breeder omschreven als bevattende de hoogste rechtspraak en het toezicht op de rechtspraak in het algemeen, de zorg voor een goed beheer, het vaststellen van wettelijke voorschriften in overleg met den Koning en de goedkeuring van bepalingen der koloniale autoriteiten. Evenals aan den Raad van Kastilië en aan andere Koninklijke Raden, was den Raad van Indië gehoorzaamheid verschuldigd. Ten aanzien van de koloniën was echter aan de andere autoriteiten elke bevoegdheid ontnomen. Ook aan de kerkelijke rechtsmacht in het Rijk in Europa, was elke inbreuk op den werkkring van den Raad verboden, wanneer het personen gold in de koloniën gevestigd, al bevonden zij zich tijdelijk in het moederland.

Het geval deed zich in 1651 voor, dat een landsdienaar, die als inwoner van Panamá door den Raad vervolgd werd, en zonder verlof in het moederland was aangekomen, zich in een klooster terugtrok. Op last van den Raad werd hij daaruit verwijderd. De kerkelijke rechter vorderde toen, dat hij aan de kerk zou worden teruggegeven, welke vordering gesteund werd door den Raad van Kastilië. Filips IV besliste echter, dat de Raad van Indië in deze uitsluitend bevoegd was, al bevond de delinquent zich in het moederland.

De Raad moest elken werkdag vergaderen met minstens drie leden. Drie dagen der week, gedurende drie uren des morgens, en drie dagen bovendien twee uren 's middags. Voor zaken van oorlog was eene afzonderlijke afdeeling, die twee malen 's weeks

\footnotetext{
${ }^{1}$ Men raadplege hierbij hoofdstuk XXIV.
} 
bijeenkwam (bl. 160). Van al het verhandelde werd aanteekening gehouden in een daartoe bestemd boek; ook van de briefwisseling met de onderkoningen en andere koloniale autoriteiten, alsmede van alle belangrijke stukken.

Vóór alles had de Raad zijne aandacht te wijden aan de verspreiding van het Katholiek geloof onder de inboorlingen der koloniën, in verband waarmede te zorgen viel voor een voldoend aantal geestelijken. Tevens was den Raad echter op het hart gedrukt om alles te voorkomen wat den inboorlingen nadeel zou kunnen doen.

In gewichtige zaken had de geheele Raad te beslissen; in andere kon de afdoening geschieden in afdeelingen («salas») van minstens drie leden. Tot eerstbedoelde zaken werden gerekend die van bestuur, wetgeving, rechtspraak, en oprichting van kerken; verder hetgeen de voorzitter daartoe meende te moeten brengen.

De beslissingen werden in het algemeen genomen bij meerderheid van stemmen. Bij staking van stemmen had men in te winnen het oordeel van de leden die bij de stemming niet tegenwoordig waren geweest. Staakten wederom de stemmen, dan werd de beslissing van den Koning ingeroepen. Voor het aannemen van nieuwe en het wijzigen van bestaande wetten, werd $\frac{2}{3}$ der stemmen vereischt.

Voor de afkondiging der wettelijke bepalingen had de Raad te zorgen, behoudens de gevallen waarin geheimhouding geraden voorkwam. Ook voor de nakoming had de Raad te waken met recht tot bestraffing van overtredingen. Verder voor de tijdige afvaart en het onderhoud van de vloot en van de koopvaardijschepen, alsmede voor de regeling van averijkosten (a vería). ${ }^{1}$

Aan den Raad van Indië kwam reeds in 1577 het recht toe om inspecties (visitas) te doen plaats hebben met voorkennis van den Koning, die den inspecteur had aan te wijzen (bl. 159). Deze inspecties, voor welke verschillende voorschriften zijn gegeven, betroffen o.a. de Cas a de Contratación te Sevilla benevens andere autoriteiten in het moederland en in de koloniën. Een ieder was verplicht om de verlangde inlichtingen op de meest volledige wijze te geven. Bleef men hierbij in gebreke, dan kon de inspecteur in naam van den Koning straffen opleggen.

Zeer wordt aangedrongen op de juiste voordracht van personen, die geroepen zullen zijn in geestelijke en burgerlijke

${ }^{1}$ Zie hoofdstuk XII. 
betrekkingen op te treden, dan wel voor bevordering in aanmerking komen, met voorkeurverleening aan hen die reeds in de koloniën gediend hebben. De voordrachten moesten volledig toegelicht zijn, en voor belangrijke ambten een drietal personen bevatten.

De benoeming tot de meest belangrijke ambten, zooals die van landvoogd en van de leden der hoogste rechterlijke colleges berustte bij den Koning op voordracht van den Raad van Indië; die tot minder aanzienlijke betrekkingen bij den betrokken landvoogd onder nadere goedkeuring van den Koning. Deze nadere goedkeuring was sedert 1610 voor de Filipijnen geen vereischte. Voorschrift was om vooral te letten op de verdienstelijke personen; in het bijzonder ook op de militairen, die voor eene onderscheiding in aanmerking kwamen. Daarentegen moest gewaakt worden tegen het bevoorrechten van verwanten en van personen, tegenover wie de mach thebbenden verplichtingen hadden. Vreemdelingen mochten niet in aanmerking komen.

Voorstellen tot het toekennen van onderscheidingen, behoorden uit te gaan van het geheele College met inachtneming van daartoe dienende voorschriften.

Zooveel mogelijk had de Raad zich te onthouden van inmenging in niet tot zijne bevoegdheid behoorende rechtszaken. Alleen indien een zeer dringende aanleiding hiertoe bestond ( $\mathrm{si}$ se ofreciere algún negocio grave y de calidad) kon een Koninklijk besluit tot inmenging worden uitgelokt. Bijzondere voorschriften golden dan. O.a. kon de Raad aangevuld worden met leden uit den Raad van Kastilië of andere staatscolleges.

Van 's Raadsarchief berustte een sleutel bij een der leden en een ander bij den oudsten secretaris. De meer dan tien jaren oude registers behoorden in het archief van Simancas ${ }^{1}$ te worden opgeborgen.

De Fiskaal van den Raad was belast met de rechtszaken, de zorg voor het regelmatig beheer der financiën en de toepassing der voorschriften voor de goede behandeling der inboorlingen. Het tweede onderwerp sloot in zich het toezicht op het personeel van de Casa de Contratación te Sevilla. De Fiskaal had hetzelfde inkomen als de leden van den Raad, en volgde in rang onmiddellijk op hen.

${ }_{1}$ Dit archief bevindt zich in een oud kasteel van middeleeuwschen aanblik, waar Filips Il een bijzondere bergplaats had voor zijne geheime stukken. Het ligt op eenigen afstand van Valladolid, de oude hoofdstad van Spanje. 
Aangaande de twee secretarissen, die in rang op den Fiskaal volgen, zijn tal van voorschriften gegeven, o.a. dit, dat zij jaarlijks alle stukken, die niet dagelijks benoodigd waren, naar het archief van Simancas moesten opzenden in overleg met den Raad.

Voor den algemeenen schatbewaarder-ontvanger van den Raad (tesorero general-receptor) zijn een aantal voorschriften gemaakt. Hetzelfde geldt van de andere aan den Kaad verbonden ambtenaren als de aguacil mayor (hoofd der politie); de relatores (verslaggevers); den escribano (griffier); de contadores (vier), die de juistheid der comptabele stukken hadden vast te stellen; de coronista mayor, die niet alleen de politieke geschiedenis had te boek te stellen, maar ook hetgeen betrekking heeft op ethnographie, natuurwetenschappen, oudheidkunde enz. Een der raadsleden was als commissaris met het toezicht belast, en jaarlijks werd $\frac{1}{3}$ van het inkomen ingehouden totdat de commissaris verklaard had tevreden te zijn over den verrichten arbeid. Het te boek gestelde kon ook openbaar gemaakt worden, indien het hiervoor geschikt werd geoordeeld. Eindelijk de cosmógrafo, die niet alleen had te bestudeeren en te beschrijven hetgeen samenhangt met aardrijkskunde, astronomie, cosmographie en scheepvaart, maar tevens hierover lezingen moest houden.

Met het bestuur in het moederland hangt zeer nauw samen de Casa de Contratación en de hiermede verbonden instellingen te Sevilla. In hoofdstukken XIX-XXI vindt men hierover gehandeld.

\section{Casa de Contratación de las Indias ${ }^{1}$.}

\section{$\S 1$. Samenstelling en werkkring.}

Door de Reyes Católicos in 1503 te Sevilla opgericht tot bevordering van scheepvaart en handel tusschen het moederland en de koloniën, maar vooral ook tot het houden van toezicht op dien handel, werd aan de Casa de Contratación toegewezen het oude paleis (Alcazar) der Moorsche koningen, met de noodige

1 Het gelukt mij niet eene bevredigende vertaling van deze benaming te geven. Koloniaal Contraotshuis beantwoordt niet aan de zeer samengestelde bevoegdheden der instelling.

Het is ook ondoenlijk om alle ambten met Nederlandsche woorden weer te geven, omdat de ambtsverrichtingen dikwijls in elkander grijpen. 
woonhuizen ${ }^{1}$ voor de hoofdpersonen. Dezen bestonden uit een voorzitter en zes leden, van wie drie jueces oficiales genaamd, onderscheiden in tesorero, contador en factor, en drie aangeduid als jueces letrados de número. Verder was er een Fiscal, benevens een uitgebreid personeel, ondergeschikt aan de juist genoemden.

De benaming van jueces, hetgeen eigenlijk rechters beteekent, hield verband met het feit, dat het College ook bemoeienis had met rechtspraak, al was deze dan in het bijzonder opgedragen aan de letrados (juristen).

Dagelijks moest vóór den aanvang der werkzaamheden de mis gelezen worden door een daartoe opzettelijk aangestelden geestelijke in een kapel van het paleis. Daar hadden ook de missen plaats voor in de koloniën overleden staatsdienaren.

In bijeenkomsten van den voorzitter, de zes leden en den Fiskaal werden de voornaamste zaken behandeld. De rechtszaken bleven voor de jueces letrados.

Allen moesten dagelijks gedurende drie uren voor het werk beschikbaar zijn, en wel van 7 tot 10 uur, dan wel van 8 tot 11 uur, naar gelang van de jaargetijden. Drie malen 's weeks moesten zij ook 's middags om 3 of 5 uur tegenwoordig zijn, zoolang blijvende als noodig was voor de afdoening van zaken. Behoudens bijzondere opdracht van het College, mocht geen der leden op eigen gezag eenige beslissing nemen. Er werd aanteekening gehouden van elke afwezigheid, waarvan de gegrondheid moest blijken, daar anders het traktement over de dagen van afwezig zijn werd ingehouden.

Voor de inrichting der vergaderzaal waren zekere eischen gesteld, o. a. tot aanduiding van de plaats voor autoriteiten, die op bijzondere onderscheiding recht hadden, bijv. de leden der Universidad de los mareantes ${ }^{2}$, an wier verzoek om advies zoo spoedig mogelijk moest worden voldaan.

De voornaamste bezigheid der Casa de Contratación bestond in de zorg voor alles wat betrekking had op de scheepvaart, het verkeer en den handel met de koloniën, alsmede op het bestuur aldaar, waaromtrent aan de Regeering berichten en adviezen moesten worden gegeven.

1 Bij gebreke van een woonhuis werd eene vêrgoeding genoten van 3000 dukaten 's jaars.

2 Zie hoofdstuk XXI. 
De Casa de Contratación was ook belast met de rechtspraak betreffende alles wat op de reizen tusschen moederland en koloniën geschiedde, zoowel burgerrechtelijk als strafrechtelijk; ook wat aanging slechte zeemanschap en bedriegelijke handelingen ten aanzien van schip en lading.

Gold het misdrijven waartegen de doodstraf dan wel eenige verminkende straf bedreigd was, dan was de berechting opgedragen aan de jueces letrados. De gewone rechter was alleen dan bevoegd, wanneer het rechtsgedingen betrof tusschen personen buiten den staatsdienst, en wanneer partijen de voorkeur gaven aan diens beslissing.

In zeezaken waarin vele personen gelijktijdig betrokken waren, was de Casa de Contratación bevoegd tot eene waarde van 600.000 maravedis, en indien partijen er in bewilligden, ook daarboven. Er stond dan hooger beroep open op den Raad van Indië, met dien verstande dat de eerste uitspraak dadelijk kon worden ten uitvoer gelegd, behoudens zekerheidstelling voor het geval van tenietdoening van het eerste vonnis. Appel op den gewonen rechter was uitgesloten.

De Casa de Contratación was belast met de zorg, dat de uit de koloniën aangebrachte brieven en stukken voor den Koning onmiddellijk in ontvangst genomen en doorgezonden werden. Ook moest zij waken tegen schending van het postgeheim. Stukken voor het College bestemd, mochten alleen in de vergadering geopend worden.

Over en weder was het plichtmatig voor den gewonen rechter en voor de Casa de Contratación om elkander te steunen ten aanzien van uitgevaardigde bevelen, tot elks bevoegdheid behoorende. De executie werd echter opgedragen aan de eigen rechtsbeambten (alguaciles) van het College.

Aan het licht gekomen strafbare handelingen bij inspecties van schepen te Sevilla en elders, waarbij de jueces oficiales zich door eigen rechtsbeambten (alguaciles) mochten doen vergezellen, hadden zij zelf te onderzoeken, en vervolgens in handen te stellen van de jueces letrados voor verdere behandeling.

In raadkamer bracht de jongste in benoeming het eerst zijn oordeel uit, en zoo vervolgens. De uitspraken werden door allen geteekend, te beginnen met het oudste lid.

Wanneer in financieele aangelegenheden geen overeenstemming 
was te verkrijgen tusschen den voorzitter en de jueces of iciales, kon de beslissing van den Koning worden ingeroepen onder overlegging van de ter zake dienende stukken en inlichtingen.

$\mathrm{Al}$ het goud en zilver, alsmede de parels en edelgesteenten uit de koloniën moesten op straffe van verbeurdverklaring aan de Casa de Contratación geconsigneerd en dan verder verhandeld worden door de jueces oficiales. Alle waarden werden in een brandkast, met drie verschillende sleutels, persoonlijk bewaard door den tesorero, den contador en den factor, die de opening en sluiting gezamenlijk hadden te verrichten. Later (1630) werden voor de onderscheiden waarden afzonderlijke brandkasten bestemd, en was een der griffiers belast met het inschrijven van hetgeen daarin geplaatst werd. Ingeval van belet van een der sleutelbewaarders, wees de voorzitter een tijdelijken vervanger aan. Aan het voor den Staat aangevoerde goud en zilver mocht alleen met toestemming van den Koning eene andere bestemming worden gegeven dan het doen verwerken in de munt te Sevilla.

Edele metalen en andere kostbaarheden, bestemd voor niet te Sevilla woonachtige personen, moesten in een afzonderlijke brandkast als voren met drie sleutels worden bewaard, totdat de aflevering kon geschieden. Eene bijzondere boekhouding was, evenals voor alle andere onderdeelen der administratie, voorgeschreven.

Jaarlijks had het College eene rekening van al het ontvangene en uitgegevene in te dienen aan den Koning door tusschenkomst van den Raad van Indië.

Inboorlingen, die in strijd met de voorschriften in het moederland aanwezig bleken, moesten door voorzitter en leden der Casa de Contratación worden teruggezonden op kosten der overtreders, die bovendien de bedreigde straffen ondergingen.

In eenige afzonderlijke titels worden de werkzaamheden van het College nader omschreven als de zorg: voor de naar de koloniën vertrekkende oorlogs- en handelsschepen, ook wat betreft de proviandeering, de bewapening en de lading, welke aan zekere eischen hadden te voldoen; voor uit de koloniën aankomende handelslieden en passagiers, voor wie een goede behandeling en spoedige doorlating waren voorgeschreven, terwijl de schepelingen op dadelijke regeling van hunne gage recht hadden; voor de inning van gelden aan de schatkist toekomende ter zake van scheep- 
vaart; voor de zich voordoende averijen; voor de nalatenschappen van aan boord overleden personen.

De voorzitter had met de rechtspraak alleen bemceienis, indien hij letrado (jurist) was; in dit geval gaf bij staking der stemmen de zijne den doorslag.

Hij had zijn gezag te doen gelden met de vereischte vormelijkheid, niet alleen tegenover zijne medeleden en het overig personeel, maar ook ten aanzien van andere autoriteiten.

De voorzitter was in alles ondergeschikt aan den Raad van Indië, en had dien voortdurend op de hoogte te houden van alle aangelegenheden waarmede de Casa de Contratación bemoeienis had. Den Raad was een voortdurend toezicht opgedragen. De voorzitter mocht zich alleen van Sevilla verwijderen om in Cadix of Sanlúcar de belangen van de vloot te bevorderen; hij had dan van zijn afwezigheid bericht te geven aan den Raad. Voor andere dienstreizen had hij voorafgaand verlof noodig. De medeleden, de Fiskaal en het overig personeel mochten zich in geen geval verwijderen zonder uitdrukkelijke machtiging o. a. van het geheele College.

De zekerheidstelling bij de aanvaarding van het ambt bedroeg van 10 tot 30.000 dukaten voor ieder, en moest om de vijf jaren herzien worden.

Het was verboden aanbevelingsbrieven naar de koloniën mede te geven, zich borg te stellen voor daarheen vertrekkende personen, voor hen eenig goud in bewaring te nemen, middellijk of onmiddellijk belangen te hebben bij handel en scheepvaart, op straffe van verbanning.

Een aantal voorschriften betreffen de onderlinge verdeeling van werkzaamheden en de te voeren administratie en boekhouding. In 1606 bestonden naast den contador, den tesorero en den factor, nog leden belast met de registers, met de goederen van overledenen, met de depositos en met de passagiers. De verdeeling geschiedde in onderling overleg door het College.

De drie "jueces letrados», belast met de rechtspraak, hadden de procesorde te volgen van de "Audiencia de Grados» 1 te Sevilla. Overigens had dit rechterlijk college geen bemoeienis met de rechtszaken der Casa de Contratación.

De Fiskaal, die in rang volgde op de «jueces", vertegen-

1 Het hoogste rechtscollege. Elders is ook sprake van de Audiencias van Valladolid en Granada. 
woordigde het openbaar gezag met adviseerende stem. Hij had ook boek te houden van de op zijn advies verleende vergunningen aan particuliere schepen en niet-ambtelijke personen om de reis naar de koloniën te ondernemen.

In dienst van de Casa de Contratación waren ook "alguaciles", "porteros", "visitadores" (opzichters der schepen), en "procuradores", die bij de geschillen voor de Jueces letrados gevoerd, hun ambt hadden te vervullen.

$\mathrm{Er}$ was ook een afzonderlijke gevangenis met een cipier (alcaide) en verder personeel.

De te Cadix aangestelde "Juez oficial de registros" had voor de met bijzondere vergunning te Cadix aankomende dan wel vandaar uitzeilende schepen en de daarmede vervoerde personen en goederen dezelfde bemoeienis als anders was voorgeschreven, behalve in rechtszaken, die uitsluitend te Sevilla mochten worden behandeld, behoudens gevallen van spoed wanneer een schip op het punt stond te vertrekken. Later kreeg de ejuez oficial, te Cadix ook andere rechtsmacht, welke hem dan door het College te Sevilla werd opgedragen, en waaromtrent hij verantwoording had te doen. Zooveel mogelijk moest hij zich onthouden van eigen uitspraak en de stukken overzenden naar het College te Sevilla. Hij werd dan ook niet ter zijde gestaan door een Fiskaal, doch kon wèl een gerechtsdienaar aanstellen. Aan de autoriteiten te Cadix was opgedragen zich niet in te laten met zaken die handel en scheepvaart der koloniën betroffen, doch wel den juez te doen terzijde staan in de uitvoering van door hem gegeven bevelen. De juez kon ook scheepsgezag uitoefenen in Málaga en andere havens van Andalucia en Granada. Achtte men te Sevilla in eenig geval bijzondere maatregelen noodig, dan kon een der jueces van daar worden afgevaardigd om den juez te Cadix ter zijde te staan. Het mocht echter niet dezelfde zijn, die voor de uitrusting van de vloot gezorgd had.

Te Cadix mochten geen vreemdelingen zich inschepen.

Schepen, die in ontredderden staat Cadix binnenliepen, mochten daar lossen, met dien verstande, dat de aangevoerde kostbaarheden dadelijk naar Sevilla gebracht werden met de daarbij behoorende scheepspapieren om op de voorgeschreven wijze te worden behandeld.

Het op eigen gezag zonder begeleiding uitzeilen van schepen 
was verboden. Het gebeurde wel eens, dat een sclfip heette koers te zetten naar de Canarische eilanden, terwijl het ten slotte naar de koloniën ging. Hiertegen moest gewaakt worden. In verband hiermede worden op deze eilanden vertegenwoordigers der Casa de Contratación vermeld.

In 1561 werden n.l. voor de drie grootste der Canarische eilanden, Gran Canaria, Tenerife en Palma, elk een Juez oficial aangesteld met gelijke bevoegdheden als in Cadix. Deze «jueces oficiales de registros» hadden tevens rechtsmacht in burgerlijke en strafzaken in verband met hunnen werkkring; zij mochten verboden waren in beslag nemen, en voorloopige hechtenis gelasten. $\mathrm{Zij}$ werden bijgestaan door escribanos en alguaciles, de laatstgenoemden belast met de uitvoering van de rechterlijke bevelen. De gewone rechter had zich van inmenging te onthouden. Geldboeten werden bij de ontvangers gestort, en jaarlijks overgemaakt aan de $\mathrm{Casa}$ de Contratación, met verslag aan den Raad van Indië. Het inkomen bedroeg 200.000 maravedis per jaar, waarvan de helft betaald werd uit de opgelegde boeten en de andere helft uit de kas van den Raad van Indië.

In 1657 werden de drie jueces oficiales vervangen door één juez superintendente op Tenerife met twee plaatsvervangers op beide andere voornoemde eilanden. Wanneer schepen uit de koloniën terugkeerende de eilanden aandeden, hadden zij drieërlei soort rechten te voldoen evenals in Sevilla, nl. de avería, de consulaatsgelden en de almojarifazgo (invoerrecht). $\mathrm{Zij}$ mochten geen goud, zilver, parels, añir, granen en cochinille lossen, maar wel huiden. Overigens moesten de voor Sevilla geldende voorschriften worden inachtgenomen, en was met de andere Canarische eilanden onder het noodige toezicht ook handel toegelaten. Voor schepen, die uit Sevilla naar de Canarische eilanden gingen vertrekken, moesten de gezagvoerders en eigenaren zekerheid stellen, dat men naar Sevilla zou terugkeeren. Bij vertrek van de eilanden naar de koloniën, mochten alleen vruchten worden ingeladen; geen enkel soort goed uit het moederland; bovendien alleen door Spanjaarden, of als zoodanig te beschouwen personen, n.l. zij die meer dan 10 jaren op Spaansch gebied gevestigd waren geweest. Hierop noest streng gelet worden.

Had een vreemdeling zijn schip aan een Spanjaard verkocht, 
dan ontleende hij hieraan niet het recht om aan boord mede te varen naar de koloniën. De bewoners der Canarische eilanden mochten zich niet zonder verlof daarheen begeven. Passagiers mochten niet om de Kaap Verdische eilanden of Brazilië gaan. Schepen, die zonder verlof van de Canarische eilanden naar de koloniën voeren, werden verbeurd verklaard. Schepen om deze eilanden varende, moesten streng onderzocht worden. Slechts bij uitzondering werden zij tot den handel toegelaten. Terugkeerende mochten zij geen goud of zilver inladen.

\section{§ 2. Handel in edele metalen.}

De koopers van goud en zilver te Sevilla waren sedert 1608 verplicht eene vennootschap te vormen uit minstens twee personen bestaande, ten einde een zekerheidskapitaal te vormen van 20.000 dukaten ten genoege van het Consulaat $^{1}$ voor al hunne aankoopen van edel metaal, en voor hetgeen zij aankochten uit de nalatenschappen van overledenen. Dergelijke vennootschappen mochten geen borgen zijn voor anderen. Het was ook niet toegestaan onder dezen beslag te leggen op edele metalen, die zij van de Casa de Contratación voor derden hadden ontvangen. In $1678 \mathrm{kwam}$ het voorschrift, dat zij de staven goud en zilver niet in dien vorm mochten verkoopen, doch verplicht waren ten spoedigste, uiterlijk binnen vier maanden, daarvan geldstukken te doen aanmunten in een der vier Staatsmunten (bl. 174). Dit alles geschiedde onder toezicht van de Casa de Contratación met inachtneming van een aantal administratieve bepalingen. Op niet-nakoming van voormelden termijn stond eene geldboete van 4000 dukaten voor de eerste maal, en 10 jaren gevangenisstraf met verbeurdverklaring van alle goederen en verlies van het ambt ingeval van recidive.

\section{§3. Nalatenschappen.}

In de Casa de Contratación moest aanwezig zijn een geldkist met drie onderscheidene sleutels waarin dadelijk bij ontrangst door het College werden opgeborgen al het goud, zilver, edelsteenen, parels en andere goederen toebehoord hebbende aan personen, die in de koloniën of op reis vandaar overleden waren. Van de boekhouding werd jaarlijks rapport uitgebracht

${ }^{1}$ Consulado de mar. Zie hoofdstuk XX.

Dl. 79. 
aan den Raad van Indië. Alles onder bedreiging van zware geldboeten bij niet-nakoming. Van voormelde goederen werden lijsten aangeplakt op een deur van de $\mathrm{C}$ a s a en van de kathedraal, terwijl bovendien aan de familieleden en bekende erfgenamen kennis werd gegeven van al het ontvangene. Rechthebbenden hadden zich vervolgens aan te melden en van hun goed recht te doen blijken, waarvan aanteekening werd gehouden. De afgifte der goederen geschiedde met toestemming van het College op rapport van den betrokken "escribano». Twistgedingen werden beslecht door de "jueces letrados», op rapport van den "relator" en de «escribanos». Testamentaire beschikkingen ten bate van vrome werken moesten uitgevoerd worden door de erfgenamen, die daartoe de beschikking over de beschikbare bedragen hadden te ontvangen van het College. Gold het de totstandkoming van stichtingen, dan was de bemiddeling van den ¿juez ecleciástico» noodig.

De rekening en verantwoording betreffende de goederen van overledenen was opgedragen aan de contadores de avería ${ }^{\mathbf{1}}$, met de verplichting om daarover rapport uit te brengen aan den Raad van Indië. Met die rekening en verantwoording was in het bijzonder belast het daartoe aangewezen lid van het college, aangeduid als "Contador juez oficial». Uit de bezittingen van overledenen mochten in geen geval leeningen worden verstrekt. Bleek na een jaar sedert de bekendmakingen dat niemand aanspraak maakte op de aangebrachte goederen, dan kwam het beheer in handen van den "depositariogeneral, van Sevilla.

\section{§ 4. Handelsovereenkomsten.}

Overeenkomsten betreffende den handel op de koloniën mochten alleen gesloten worden ten overstaan van de vier daarvoor bij de Casa de Contratación aangestelde als notarissen fungeerende "escribanos de Cámara", die in dit gebouw kantoor hielden en op bepaalde uren aanwezig moesten zijn. $\mathrm{Te}$ hunnen overstaan hadden ook de beëedigingen plaats van de bevelvoerende officieren van leger en vloot en andere autoriteiten op of voor de vloot werkzaam, en de ambtsverrichtingen in verband met de personen, die met de vloot in betrekking stonden. De «escribanos " hadden met het oog hierop recht inzage te nemen van de bij de Casa de Contratación

1 Zie hoofdstuk XII. 
berustende stukken, alsmede van de aanhangige geschillen en de daarin gevelde vonnissen. $\mathrm{Zij}$ gaven ook verklaringen af over den diensttijd en bewezen diensten, alsmede uittreksels uit de registers.

Een der aescribanos, was in het bijzonder belast met de verdeeling der werkzaamheden betreffende de bestaande geschillen. Hij voerde den titel van "repartidor» en genoot een inkomen van 10.000 maravedis. Voor elke handteekening was 8 maravedis verschuldigd. Een der "escribanos" had den "Juez oficial" te vergezellen, wanneer deze naar Sanlúcar of Cadix ging. Allen hadden de Contadores de avería bij te staan wanneer dezen dit noodig achtten.

\section{§ 5. Post.}

Aan de Casa de Contratación was een ambtenaar verbonden, die alle postzaken had te regelen tusschen moederland en koloniën. Zijn titel was “Correo mayor». Tot zijne beschikking had hij te Sevilla en op andere plaatsen goed opgetuigde paarden en het noodige personeel voor de spoedige bezorging van brieven. $\mathrm{Hij}$ mocht de bediening niet uitbesteden, en had niet het recht om den een eerder te bedienen dan den ander. Gold het brieven voor den Koning, dan moest vooraf aan den Raad van Indië gevraagd worden of iets mede te geven was. Zoo ook aan de Casa de Contratación en aan het Consulaat (Consulado de mar). De kosten van iedere postverzending werden begroot door eerstvermelde instelling en op haren last uitbetaald.

In 1628 bedroeg de porto op brieven uit de koloniën komende 1 reaal per ons; waren zij zwaarder dan 1 pond, dan werd het meerdere berekend tegen $\frac{1}{2}$ reaal per ons.

Personen in het moederland en de koloniën hadden het recht van vrije briefwisseling. In 1592 werd het postgeheim uitdrukkelijk erkend, nadat gebleken was dat de brieven weleens geopend werden.

Verbonden aan de Casa de Contratación vallen te vermelden twee instellingen te Sevilla, aan te duiden als: Consulado de mar (Rechtspraak in zaken van scheepvaart en handel) en Universidad de mareantes (Vereeniging van bij de scheepvaart betrokkenen). 


\section{Consulado de mar (Rechtspraak in zaken van scheepvaart en handel).}

Men denke zich dit consulaat niet in den thans gebruikelijken zin van vertegenwoordiging in vreemde landen, maar als een instelling van rechtspraak in zee- en handelszaken in het eigen land. ${ }^{1}$

1 De instelling van handelsconsuls als rechters in handelszaken bestond reeds lang te voren in andere plaatsen ran Spanje en Italië, onder den naam van Consulad os de mar. De bedoeling was, om toen de scheep vaartverhoudingen bijna uitsluitend door het gewoonterecht beheerscht werden, de rechtspraak te doen geschieden volgens het deskundig oordeel van goede mannen met terzijdestelling van het Romeinsche recht, en in het bijzonder van de lex Rhodia. Kernachtig drukte Keizer Antoninus dit uit, toen eens zijn oordeel gevraagd werd omtrent eene scheepvaartzaak: „ego quidem terrae dominus, lex autem maris". Ik ben wel heerscher van het land, maar de wet is heerscheres van de zee.

De eerste Consulado de $\mathrm{mar}$ is die van Messina (15 Mei 1128), bestaande uit twee consuls, te kiezen uit praktisch ervaren zeelieden.

De tweede van Genua (1250), de twee consuls bijgestaan door vier burgers met raadgevende stem.

De derde van Venetië (1280), samengesteld uit 20 leden, later vervangen door de rechtbank delli sopra consoli, in het begin der XIV• eeuw genaamd "delli cinque savi alla mercansia".

Voor het Rijk (Corona) van Aragon, dat zich in de $13^{\circ}$ en $14^{\circ}$ eeuw langs een groot deel van Spanje's oostkust, een deel van Zuid Frankrijk en de Balearen uitstrekte, kwamen in $1283,1343,1347$ en 1348 consulados de $\mathrm{m}$ ar tot stand voor Valencia, het eiland Majorka, Barcelona en Perpignan. Ook in andere plaatsen van Oost-Spanje zooals Gerona, Tortosa, Tarragona enz., waar de handelsconsuls ook als procuradores of administradores werden aangeduid.

Bilbao volgde in 1514 en Sevilla in 1543 onder Karel I (V).

Parijs en Toulouse kregen eerst in 1563 en 1549 de instelling.

De uitspraken werden te boek gesteld, en vormden langzamerhand een geschreven gewoonterecht, dat o.a. voor Barcelona als "libro del consulado" groot gezag verkreeg, reeds sedert 1266, want het besluit van 1347 was slechts de ambtelijke erkenning van hetgeen reeds lang te voren bestond. De tekst was een mengelmoes van Katalaansch, Spaansch, Italiaansch en Limousin.

Vóór de oprichting van het consulaat te Sevilla, berustte de rechtspraak in zeezaken bij de Jueces letrados van de Casa de Contratación. In $1554 \mathrm{kwam}$ daar een afzonderlijk samenstel ran wettelijke bepalingen tot stand, naar welke het consulaat zich te richten had, bestaande uit 27 hoofdstukken, en samengesteld door den Prior en de Consuls onder voorzitterschap van een der leden van den Raad van Indië.

Bijzonderheden omtrent de instelling vindt men in de voorrede van den Código de las Costumbres maritimas de Barcelona, uitgegeven door A. Capmany y de Monpalau (Madrid 1791). Men raadplege ook het werk van Jaime Boq. Diccionario de comercio 1839. 4 vol., en dat van Octave Noël Histoire du commerce du monde depuis les temps les plus reculés. - 
De te Sevilla bestaande instelling, breeder aangeduid als Universidad de cargadores de la ciudad de Sevilla, (Vereeniging van inladers der stad Sevilla) bestond uit twee, later drie scheepvaart-consuls, van wie de eerste den titel droeg van "Prior». ${ }^{1} \mathrm{Zij}$ waren ook bevoegd te Cadix en

1 Zijn inkomen bedroeg 40.000 maravedis 's jaars. De Consuls genoten slechts de helft.

Paris 1894. 3 vol. In deel III van Pardessus vindt men eene fransche vertaling van de oude zeewetten.

De samenkomsten der handelsconsuls hadden gewoonlijk plaats in gebouwen die in Nederland als "beurs" worden aangeduid en in Spanje den naam voeren van „lonja". Van de thans nog bestaande "lonjas" zijn de mooiste die in Valencia en in Palma, de hoofdstad van Majorka, in welk laatste thans een museum gevestigd is.

In 1592 werd de oprichting van Consulaten te Lima en te Mexico, voor Peru en Nueva España door Filips II goedgekeurd en bevestigd op het voetspoor van de consulaten te Sevilla en Burgos, met de bedoeling om den handel te bevorderen. Het consulaat van Lima kreeg den naam "Universidad de la Caridad" (Vereeniging der Barmhartigheid), en had tot wapen een gekroond schild op blauwen grond met een gouden vaas waarin een tak tuberozen, omringd met de woorden „Maria concebida sin pecado original" Maria onbevlekt (d.w.z. zonder den smet der erfzonde) ontvangen. Maria was n.l. de patrones van het Consulaat, dat zich ook uitstrekte tot Tierra Firme en Chili. Het consulaat van Mexico, dat voor geheel Nueva España, Nuevo Reino de Galicia, Nueva Vizcaya, Guatemala, Yucatán en Soconuzco gold, werd genoemd "Universidad de los Mercaderes" (Vereeniging der kooplieden), en was niet alleen aan Maria gewijd, maar ook aan San Francisco.

De Prior en de Consuls van den handel, alsmede de Diputados werden jaarlijks in het begin van Januari gekozen door een 30 tal (in Mexico) en een 15 tal (in Lima) handelslieden, die aan zekere voorschriften voldeden en daartoe door keuze aangewezen waren. De verkiezing geschiedde ten overstaan van den betrokken escribano, en werd voorafgegaan door beëdiging. De gekozenen hadden ook een eed af te leggen. Het aantal diputados bedroeg 5 of 6 . Allen waren verplicht zich de keuze te laten welgevallen op strafte van boete van 200 pesos. Het inkomen bedroeg 500 pesos 's jaars in Lima en voor Mexico het dubbele van hetgeen in Sevilla genoten werd. Aangaande de benoeming van een escribano en anderen en de geldkisten gold in hoofdzaak hetzelfde als in Sevilla, waar een vertegenwoordiger mocht worden aangesteld.

Van uitspraken door het Consulaat gedaan, stond, met uitsluiting van de gewone rechtsmacht, hooger beroep open op een Oidor der rechtbank van Lima of Mexico, daartoe door den onderkoning aangewezen. Hij legde in handen van het Consulaat den eed af, en koos vervolgens twee kooplieden uit om met hem van de zaken kennis te nemen. Werd de eerste beslissing te niet gedaan, dan koos de Oidor twee andere kooplieden om opnieuw vonnis te wijzen.

Omtrent wrakingen werd beslist door het Consulaat, met dien verstande 
Sanlúcar op te treden. $\mathrm{Z}_{\mathrm{ij}}$ vertegenwoordigden de inladers (cargadores), die hen voor twee jaren uit hun midden kozen. De verkiezing geschiedde door 30 daartoe door al de koloniale inladers aangewezenen. De kiezers, die Spanjaarden moesten zijn van minstens van 25 jarigen leeftijd, gehuwd dan wel weduwnaar, hadden vooraf in handen van een daartoe aangewezen juez oficial der Casa de Contratación den eed af te leggen. Waren op 2 of 3 personen evenveel stemmen uitgebracht, dan vermocht de "Juez oficial» den doorslag te geven. De verkiezing geschiedde met gesloten briefjes, met dien verstande dat de met de meeste stemmen gekozene Prior werd. De gekozenen hadden een eed af te leggen voor de trouwe vervulling van hun ambt. Voordat zij op nieuw verkiesbaar waren, moesten twee jaren na hun aftreden verloopen zijn. Er mocht geen nauwe bloedverwantschap of maatschappelijke band bestaan tusschen den Prior en de Consuls, noch tusschen hen en een der personen van de voorafgaande verkiezing. $Z \mathrm{ij}$ mochten ook geen belang hebben bij de heffingen op ladingen. (a $1 \mathrm{mojarifazgo)}$.

Prior en Consuls werden bijgestaan door vijf afgevaardigden ( diputados»), die raadgevend optraden en met opdrachten mochten worden belast, ook wanneer bij den Koning of den Raad van Indië iets te regelen viel.

Prior, Consuls en afgevaardigden, die hun ambt niet wilden aanvaarden, verbeurden een boete van 50.000 maravedis.

Zij hadden kennis te nemen van alle geschillen tusschen de handelslieden en handelslichamen onderling betreffende uit de koloniën aangevoerde, dan wel daarheen af te schepen waren. Ook van vorderingen tegen handelsagenten, die onwillig bleken rekening en verantwoording af te leggen van hunne verrichtingen

dat zoo noodig door den onderkoning een andere Oidor werd angewezen, en door den Oidor nieuwe bijzitters.

De escribanos waren met de executie belast, alsmede met het opmaken van stukken op de gedingen betrekking hebbend.

Ingeval van schipbreuk werden de geborgen goederen beheerd door een of meer commissarissen uit het betrokken Consulaat, dat in Mexico zelf de keus deed, terwijl de keus in Lima door den onderkoning geschiedde.

Aan de kooplieden was het houden van een zeker aantal boeken voorgeschreven, in het bijzonder waar het edele metalen gold.

Voor de makelaars en andere tusschenhandelaars (factores) golden eenige bijzondere voorschriften. 
in de koloniën. Aan de uitspraken moest door de gewone autoriteiten uitvoering worden gegeven. Strafbare handelingen werden ter berechting aan de Casa de Contratación overgelaten.

Faillissementen van kooplieden en inladers te Sevilla en Cadix werden sedert $162 \bar{j}$ afgewikkeld door het Consulaat, behalve wanneer het groote bankinstellingen gold. Hooger beroep was toegelaten op den Raad van Indië. Kwamen bedriegelijke handelingen aan het licht, dan behoorde de berechting te geschieden door de Casa de Contratación. De leden van het Consulaat genoten de onderscheiding aan rechters toekomende. Hunne brieven voor den Koning bestemd gingen door tusschenkomst van de Casa de Contratación, welke hare beschouwingen bijvoegde. De zittingen van het Consulaat hadden plaats in het gebouw der voormelde Casa. Ingeval van wraking van een of van beide Consuls, traden die van het vorig tijdvak als rechters op.

Tot dekking der kosten van het Consulaat werd van alle inladers op de uitgaande goederen geheven suna blanca al millar, (1 op de 1000) van hetgeen als "almojarifazgo, (belasting op ingeladen goederen) verschuldigd was. Voor de ontvangst hiervan had te zorgen een "receptor" of «bolsero", die jaarlijks zijne rekening aan de goedkeuring van den Raad van Indië had te onderwerpen door tusschenkomst van de Casa de Contratación. Dezelfde verplichting rustte op het Consulaat. Dit laatste had ook de zorg voor de verdeeling van goederen, gered uit schipbreuk geleden hebbende vaartuigen. Het was bevoegd om voorschriften uit te vaardigen, die echter de voorafgaande goedkeuring van den Raad van Indië behoefden.

In 1606 werd aan inladers (cargadores) en handelaren verboden om langer beurs te houden bij de deur van San Cristóbal in de Kathedraal. Dit moest voortaan geschieden in de daartoe gebouwde "Lonja.

\section{Universidad de Mareantes (Vereeniging van bij de scheepvaart betrokkenen).}

Deze Vereeniging bestond uit de scheepseigenaren, gezaghebbers en andere aan de scheepvaart deelnemende personen van onderscheiden rang. Het bestuur der Vereeniging had o. m. advies te geven bij de aanstelling van scheepskapiteins.

Ten behoeve van de Vereeniging werd in den aanvang van 
de naar de koloniën vertrekkende schepen de "media sol$\mathrm{d} \mathrm{a} \mathrm{d} \mathrm{a}^{1}$ geheven. In 1608 werd deze gebracht op $1 \frac{1}{2}$ reaal per ton.

Omstreeks denzelfden tijd kwam de bepaling, dat schepelingen, die na 10 jaren dienst bij de koopvaardij, dan wel 6 jaren dienst bij de marine, wegens ouderdom of andere redenen niet meer varen konden, vrijstelling van belastingen en inkwartiering zouden genieten. In 1619 kwam voor de scheepseigenaren vrijstelling van verschillende heffingen.

De leden der Vereeniging waren onttrokken aan de gewone rechtsmacht, en onderworpen aan die der kapiteins-generaal in eersten aanleg, en aan die der Casa de Contratación in hooger beroep, en in ernstige gevallen aan die van den Raad van Indië.

\section{Wetgeving.}

\section{$\S 1$. Indeeling der wettelijke bepalingen.}

De wetgeving ${ }^{2}$ bestond uit: leyes (wetten), provisiones (algemeene voorschriften uitgaande van den Raad van Indië), cédu la s (ambtelijke voorschriften van den Koning aan de koloniale besturen) en ordenanzas reales (Koninklijke besluiten).

De vocrschriften uitgaande van de koloniale besturen werden eveneens als ordenanzas aangeduid.

Bij de afkondiging van de eerste als codificatie te beschouwen verzameling wettelijke bepalingen onder Filips IV, verordende hij, dat in niet voorziene gevallen zouden zijn te volgen de wetten voor het moederland geldende, in het bijzonder die in de ¿Siete Partidas, vervat. Dit was trouwens reeds in 1530 door Karel I (V) gelast ${ }^{3}$.

I Media soldada beteekent letterlijk: half salaris. Vermoedelijk is dit laatste woord hier op te vatten in den zin van vrachtprijs.

- Men vergelijke hierbij hoofdstuk XVIII § 2 .

3 Hieraan had Filips III in 1602 toegevoegd, dat voor het mijnwezen de wetten van het Rijk moesten worden opgevolgd, tenzij zij in strijd waren met hetgeen voor eenig deel van het Rijk is vastgesteld, in welk geval hiervan rapport behoorde te worden uitgebracht.

Onder de "Siete Partidas" verstaat men de zeer uitgebreide codificatie, omstreeks het midden der XIII ${ }^{\bullet}$ eeuw door Fernando III aangevangen en door zijn zoon Alfonso X (1252-1284) in 1263 voleindigd. De naam duidt op het zevental "boeken" waarin de codificatie is ingedeeld, en hangt samen met de groote waarde sedert oude tijden aan het getal zeven gehecht.

Bij den dood van Alfonso $\mathrm{X}$ was de afkondiging nog niet geschied; deze 
In 1555 bepaalde hij verder, dat de gebruiken der inboorlingen die zij ook na hunnen overgang tot het Christendom wenschen te volgen, van kracht zullen blijven, v. z. v. zij niet in strijd zijn met den Katholieken godsdienst of met de in de verzameling opgenomen wetten, en niet klaarblijkelijk onrechtvaardig voorkomen ('guardando los usos y costumbres no siendo claramente injustos ).

Ook moesten ongerept blijven alle voorschriften in het belang van de inboorlingen gegeven, in verband waarmede al het in de koloniën te hunnen behoeve verordende onder de aandacht van den Vorst moest worden gebracht, door tusschenkomst van den Raad van Indië. Hun moest, ook tegenover niet-inboorlingen, spoedig recht verschaft worden met zoo weinig mogelijk kosten, en met vermijding van de vertragingen die sommige advokaten en procureurs op arglistige wijze weten te scheppen ( $\mathrm{ni}$ haya dilaciones como suele acontecer por la malicia de algunos abogados y procuradores s).

Als algemeene beginselen golden overigens: $1^{\circ}$ dat geen wettelijke bepalingen ( ninguna pragmática») van het moederland in de koloniën van kracht waren, indien dit niet bevolen werd bij Koninklijk besluit door tusschenkomst van den Raad van Indië; $2^{\circ}$ dat de koloniale wetten zooveel mogelijk overeen moeten stemmen met die van het moederland, ook wat de procedure betreft.

\section{§2. Misdrijven en straffen.}

De wetten betreffende godslastering in Spanje van kracht, werden in 1543 toepasselijk verklaard in de Indias. Ook die over valsche getuigenis en echtbreuk (zonder onderscheid tusschen Spaansche en mestiezen-vrouwen). De in Spanje bedreigde geldboeten moesten in de Indias dubbel worden berekend. Dit gold in het bijzonder bij vervolging van in concubinaat levende Spanjaarden.

bleef ook onder de opvolgers Sancho IV en Fernando IV achterwege. Eerst Alfonso XI bepaalde in 1330 bij zijn Ordenamiento de Alcalá, dat de Siete Partidas kracht van wet zouden hebben boven de Fueros, met welk laatste woord $o$. a. het gewoonterecht wordt bedoeld.

Eerst in 1491 zijn de Siete Partidas op last van de Reyes Católicos in druk verschenen.

Van de uitgebreidheid van deze codificatie en de veelheid van onderwerpen daarin behandeld, krijgt men eenig denkbeeld door de mededeeling, dat zij in druk 452 bladzijden beslaat. 
De tot galeistraf en verbanning veroordeelden werden naar Tierra-Firme gevoerd, later ook naar de Filipijnen. Eerstgenoemde straf mocht niet op personen van adel worden toegepast. De doodstraf moest worden ten uitvoer gelegd op de wijze in Spanje voorgeschreven, d.w. z. door de garote (wurgpaal met ijzeren band, welke door een kruk wordt dichtgeknepen). Geldboeten kwamen ten bate van de schatkist. Onder de lijfstraffen kwam voor het met spijkers doorboren van de handen («clavar la mano»).

De misdrijven, die vooral bestraft moesten worden, zijn die van godslastering, toovenarij, het buiten echt leven, en het houden van huizen van ontucint.

\section{§ 3. Hazardspel.}

Met kracht moest worden opgetreden tegen het hazardspel. In 1529 werden bepaald aangeduide spelen verboden, zoowel met dobbelsteenen als met kaarten. In geen geval mocht in 24 uren meer dan 10 pesos in goud worden verspeeld. Later, in 1609 , werd het hazardspel geheel verboden, in het bijzonder aan de landvoogden en andere hooge ambtenaren.

\section{Bestuur in de overzeesche gewesten.}

\section{$\S 1$. Algemeene beginselen.}

Het vijfde boek behandelt verscheidene bestuursindeelingen en de toekenning van bevoegdheden, alsmede de wijze waarop benoemingen geschieden voor de hoogere ambten, n.l. hetzij door den Koning hetzij door den Raad van Indië, (zie bl. 137), en de aan die ambten verbonden bezoldigingen. ${ }^{1}$ In enkele gevallen waren de landvoogden bevoegd openkomende plaatsen

1 Op het voetspoor van hetgeen onder de Reyes Católicos (Isabel la Católica en Fernando) gebruikelijk werd, kwam in 1522 de bepaling, dat een aantal ambten van lagere orde in de koloniën verkocht konden worden aan degenen, die zich met de vervulling belast wenschten te zien, en aan wie tevens de geschiktheid daarvoor werd toegekend. Deze gewoonte bestond nog in 1670 . De gekochte ambten konden door de koopers aan anderen worden overgedragen onder nadere goedkeuring der overheid. $\mathrm{Bij}$ die gelegenheid was de helft of een derde van den overdrachtprijs aan de schatkist verschuldigd, al naarmate de overdracht voor de eerste, dan wel voor de tweede maal geschiedde. Betaling op langen termijn was hierbij niet veroorloofd. Verder bestonden een aantal voorschriften van administratieven aard. 
tijdelijk aan te vullen. De ambtseed werd afgelegd in den Kaad van Indië. Het eedsformulier van 1536 is bijzonder uitvoerig, maar houdt in het wezen der zaak hetzelfde in als de formulieren van den tegenwoordigen tijd. Sedert 1622 waren de hoofdambtenaren verplicht bij het aanvaarden van hun ambt een inventaris van hunne bezittingen over te leggen. In 1551 hadden zij reeds zekerheid te geven voor hun beheer. De diensttijd bedroeg 5 dan wel 3 jaren, al naar mate men in het moederland dan wel daarbuiten werd benoemd. Een lange reeks ambtelijke voorschriften geven een denkbeeld van de toenmalige opvattingen, die uit het voorafgaande reeds bekend zijn. Zoo wordt bijv. herhaald, dat groote aandacht te wijden valt aan de inheemsche instellingen, die gehandhaafd behooren te worden voor zoover zij niet in strijd zijn met den heiligen godsdienst; dat de inboorlingen beschermd moeten worden tegenover hunne hoofden en tegen afpersingen van wie ook.

In afzonderlijke titels worden de ambtsplichten en bevoegdheden geregeld van hoogere en lagere landsdienaren: de gouverneurs (gobernadores), corregidores, alcaldes mayores en lager geplaatste alcaldes. Zoo konden de alcaldes ordinarios (1561) geschillen tusschen Spanjaarden en inboorlingen beslissen.

Traktementen werden driemalen 's jaars voldaan voor reeds bewezen diensten en gingen in met den dag van vertrek uit het moederland. Bij verloven voor niet langer dan twee maanden, behield men vol traktement. Voorschotten waren niet veroorloofd dan met machtiging des Konings aan de Prelaten. Bij overlijden hield voor de erfgenamen het recht op traktement dadelijk op, en werd voor de uitbetaling eene beschikking van den Raad van Indië vereischt.

\section{§ 2. Landvoogden.}

Titel III van het derde boek handelt over de twee onderkoningen (virreyes) en de tien andere landvoogden (presidentes gobernadores).

De eerste titel werd in 1542 toegekend aan de landvoogden van Peru en van Nueva España (Mexico) ${ }^{1}$. De landvoogden, die sedert

1 Het onderkoningschap van Peru gold als aanzienlijker dan dat van Mexico. Het strekte zich uit ver buiten de tegenwoordige republiek van dien naam, zelfs tot Panamá. 
1555 voor den tijd van drie jaren werden benoemd, behoudens verkorting of verlenging, zijn, als vertegenwoordigers van den Koning, belast met het hoogste gezag op administratief en tot zekere hoogte ook op rechterlijk gebied, en hebben zorg te dragen voor de rust en den vooruitgang (ennoblecimiento) van hun territoir. Tot bereiking hiervan was hun opgedragen om den godsdienst te handhaven en aan allen deelachtig te doen worden; om hen, die zich verdienstelijk hebben gemaakt bij ontdekkingen, bij vestigingen en bij bevolking van landen, alsmede hunne afstammelingen ${ }^{1}$ te beloonen; om zeer in het bijzonder te waken voor de goede behandeling, het behoud en de uitbreiding der inheemsche bevolking; voor het juiste beheer van de geldmiddelen; en voor alles wat noodig geacht wordt voor den bloei der kolonie.

Aan elk en een iegelijk, ook aan de geestelijkheid, was de verplichting opgelegd om de landvoogden te gehoorzamen en te eerbiedigen. $\mathrm{Zij}$ waren tevens bevelhebbers (capitanes generales) van de land- en zeemacht, voorzitters van de Reales audiencias, waarover nader, en bestuurders van de provincie waarin zij gevestigd zijn. Ook hadden zij het recht van gratie, met inachtneming van ter zake bestaande bepalingen.

Gedurende hun verblijf te Sevilla hielden zij verblijf in een der paleizen, echter niet in het middengedeelte daarvan. De reis naar hun gewest maakten zij uit Sanlúcar (Cadix) aan boord van het admiraalschip der vloot met den titel van generaal der vloot, met recht om wapentuig (van elke soort twaalf) en voor een waarde van 6000 gouden pesos aan sieraden mede te nemen. Jaarlijks mochten zij voor een waarde van 2000 dukaten invoeren, zonder hiervoor rechten verschuldigd te zijn.

In 1660 werd voorgeschreven, dat zij zich niet mochten doen vergezellen door hunne zoons en dochters, noch door hunne schoonzoons en schoondochters, al waren de eersten ook nog minderjarig. Van dit verbod kon onder geen voorwaarde vrijstelling worden gegeven.

Zij mochten geen rechtszaken onttrekken aan de kennisneming van den bevoegden rechter, en hadden overigens het recht zijn loop te laten. Omgekeerd had de rechter zich te onthouden van inmenging in administratieve aangelegenheden. Meende een landvoogd in eenig bijzonder geval waarin inboorlingen betrok-

1 Dezen moesten zij bij zich nemen en behoorlijk doen opvoeden. 
ken waren, eene beslissing te moeten nemen, dan behoorde hiertegen beroep op den rechter open te staan.

$\mathrm{Bij}$ eigenhandigen brief hadden de landvoogden aan den Koning in bijzonderheden rapport uit te brengen over den gang van zaken bij het rechtswezen en over alles wat de verboden huwelijken betreft.

Hun was de zorg opgedragen voor de goede verstandhouding tusschen de hoogere geestelijkheid, en voor de verwijdering van hoogere en lagere geestelijken, die zich aan afkeurenswaardige handelingen schuldig maakten. Gold het de lageren, dan moest vooraf het gevoelen der hoogeren worden ingewonnen; betrof het hoogeren, dan werd een dadelijk rapport aan den Koning gevorderd. In elk geval was geheimhouding verplicht, tenzij het onjuist optreden openlijk was geschied, in welk geval dadelijk ingrijpen moest plaats hebben.

De landvoogden waren belast met het openen en goed doen onderhouden van verkeerswegen en bruggen, alsmede met de vaststelling van het aandeel der inheemsche bevolking in de kosten, waarbij de meeste matiging in acht te nemen viel. Een register ter zake was voorgeschreven, ook met de bedoeling om bijdragen van vroegere geslachten te benutten.

Een der praktische plichten van den landvoogd was de zorg, dat aan reizigers in de verblijfplaatsen van onderscheiden aard behoorlijk onderkomen en voeding verleend werd tegen betaling van vastgestelde prijzen, waardoor afzetterijen voorkomen moesten worden. Ook werd tegengegaan gedwongen verblijf op sommige plaatsen en opdrijving van vervoerkosten.

Het beheer der financiën, d. w. z. het ontvangen en uitgeven van gelden, behoorde te geschieden met eerbiediging van Koninklijke lastgevingen en machtigingen. In de tegenwoordige spreekwijze zou men zeggen: de begrooting van ontvangsten en uitgaven werd door den Koning vastgesteld. Alleen in gevallen van noodzaak (o.a. inval van vijanden en de daardoor noodig geworden zelfverdediging, opstand enz.) konden zonder voorafgaande machtiging des Konings uitgaven geschieden, zooveel mogelijk beperkt, en behoudens dadelijk volledig rapport aan den Raad van Indië. Dit voorschrift is van 1563, en werd sedert herhaald in 1571, 1596, 1614, 1628 en 1660.

Bij verwijdering van personen uit de koloniën, hadden de landvoogden hierop dadelijk de goedkeuring te vragen van den 
Koning, onder overlegging van de ter zake handelende stukken.

Een achttal titels van het $3^{\text {e }}$ boek behandelen zaken van oorlog als het vervaardigen wan wan en munitie, het aanleggen van versterkingen, en andere legerbelangen. Tevens de bestrijding van zeeroof. Hetgeen daarin voorkomt, heeft alleen in enkele opzichten belang. Zoo wordt bijv. erop aangedrongen om, indien inboorlingen in opstand komen, met zachtheid en toegevendheid hen tot rede te brengen, en plaats gehad hebbende ongeregeldheden te vergeven. Is gewelddadig optreden onvermijdelijk, dan behoort vooraf het welmeenen van den Koning door tusschenkomst van den Raad van Indië te worden ingeroepen, tenzij onmiddellijk ingrijpen noodzakelijk blijkt. In elk geval moet het bevel gelegd worden in handen van kundige personen. Bij het overzenden van troepen van Mexico naar de Filipijnen, mochten geen mestiezen of mulatten medegaan. De inboorlingen mochten niet worden ingewijd in het vervaardigen van wapentuig.

Aan den Koning hadden de landvoogden rapport uit te brengen over alles wat betrekking heeft op godsdienst, politiek, militair en financieel beleid. Bij het nederleggen van hun ambt moesten zij een bijzonder overzicht geven van alle belangrijke voorvallen tijdens hun bestuur. In het bijzonder dringt Filips III in 1618 opnieuw aan op goede behandeling van de inboorlingen en bescherming tegen alles wat willekeur is. $\mathrm{Hij}$ wenschte uitvoerige berichten aangaande alles wat het welzijn der inboorlingen betreft, met belooning voor allen, die in het belang der inboorlingen handelen, en zware bestraffing van hen, die dit belang benadeelen. Aan de geestelijkheid was vooral opgedragen dit doel na te streven en in alle omstandigheden te helpen bevorderen. Vooral mocht geen censuur worden uitgeoefend tegen de rechterlijke autoriteiten, die in het belang van de inboorlingen optreden.

Het gebied van iederen landvoogd was ingedeeld in gobiernos, corregimientos en alcadías mayores, ambtelijk ondergeschikt aan de $\mathrm{A} u$ udiencias y $\mathrm{Ch}$ ancillerias Reales. (Gerechtshoven en Koninklijke Kanselarijen).

\section{§ 3. Gerechtshoven tevens adviseerende colleges (Audiencias y Chancillerias Reales).}

In 1526 werd aan den landvoogd van Isla Española eene Audiencia y Chancilleria Real toegevoegd op de hoofdplaats der landvoogdij (Santo Domingo). 
In $1527,1535,1542,1543,1548,1549,1559,1563,1583$, 1609 en 1661, had achtereenvolgens hetzelfde plaats ten aanzien van de elf andere landvoogden.

De Reales Audiencias, zooals zij kortheidshalve worden aangeduid, waren samengesteld uit den landvoogd als voorzitter, oidores (afwisselend 4 tot 8 ), een fiskaal dan wel twee fiskalen, een alguacil mayor enz. Somtijds waren er ook alcaldes del crimen (strafrechters). Anders oefenden de oidores de functiën uit voor de alcaldes del crimen bestemd.

Als hoofdbeginsel gold, dat de Reales Audiencias niet alleen met de rechtspraak in hooger beroep zijn belast, doch ook optreden als adviseerende colleges in bestuurszaken. Met dien verstande evenwel, dat zij zich niet in bestuurszaken mochten mengen, dan wanneer de landvoogd, dat is dus de voorzitter, dit wenschte. Omgekeerd had deze laatste geen bemoeienis met de rechtspraak dan in bepaalde gevallen, en indien hij jurist (letrado) was.

In 1583 werd de raadpleging (“consultivamente») van de Audiencias verplichtend. Aan den landvoogd bleef echter de beslissing; met inachtneming van hetgeen het meest overeenkwam met den dienst van God en van den Koning (lo mas conveniente al servicio de Dios y nuestro) en met de bevordering van vrede en rust in het gewest en het Rijk.

Overigens was de onderlinge verhouding zeer merkwaardig. Zoo mocht ieder, die zich door een landvoogd verongelijkt achtte, herstel zoeken bij de Audiencia, buiten den landvoogd om, terwijl bij de te nemen beslissing diens tegenwoordigheid verboden was (1553 en later).

De macht der Audiencias ging zelfs zóó ver, dat zij tegenover den landvoogd op eigen gezag konden optreden, indien deze zijne bevoegdheid te buiten ging of de rechtspraak belemmerde. In verband hiermede was hun toegestaan de beslissing van den Koning in te roepen. $Z$ ij hadden hierbij echter te waken, dat de zaak geen ruchtbaarheid kreeg.

Ook individueel konden de oidores zich, zoo noodig onder overlegging van bewijsstukken, tot den Koning wenden, die dan door tusschenkomst van den Raad van Indië den landvoogd deed hooren, of een plaatselijk onderzoek gelastte. Hiertoe werden ook weleens personen uit het moederland afgevaardigd, hetgeen met het woord visita (inspectie) werd uitgedrukt (bl. 136). 
Niet geheel in overeenstemming met deze beginselen was bepaald, dat ingeval van twijfel of eenige zaak behoort tot de bevoegdheid van het bestuur, dan wel van de rechterlijke macht, de oidores verplicht waren zich te houden aan de uitspraak van den landvoogd, hoewel zij, zoowel gezamenlijk als ieder afzonderlijk, de beslissing van den Koning mochten inroepen.

Er waren ook gevallen, dat de landvoogd, daartoe door den Koning gemachtigd, en onder bekendmaking van die machtiging, aan de Audiencia mocht doen weten, dat haar gevoelen niet zou worden gevraagd.

Brieven voor de Audiencias bestemd, mochten door den landvoogd slechts geopend worden in tegenwoordigheid van de oidores, de fiskaals en een griffier (escribano).

In het algemeen hadden de Audiencias - behalve bij ontstentenis van den landvoogd, tevens kapitein-generaal - geen bemoeienis met militaire zaken; ook niet bij wijze van beroep. Ieder, die grieven had op militair gebied, kon zich wenden tot de Koninklijke Commissie ad hoc (Junta de Guerra de Indias), aan den Raad van Indië verbonden.

Bij ziekte of overlijden van den landvoogd trad de Audiencia als tijdelijk vervangster op. De oudste oidor was dan voorzitter.

Een algemeene verplichting van de Oidores tegenover den landvoogd was, om dezen te wijzen op al het belangrijke dat zich voordeed. De landvoogd was gehouden hieraan de noodige aandacht te schenken.

In een zeer uitvoerigen titel (XV) van Boek II vindt men voormelde verhoudingen omschreven. Daar zijn ook vermeld de gewestelijke hoofdplaatsen, waar Audiencias gevestigd waren, in de op bl. 159 vermelde volgorde n.l.: Santo Domingo, Mexico, Panamá, Lima, Santiago de Guatemala, Guadelajara, Santa Fé de Bogotá, de la Plata, San Francisco de Quito, Manila, Santiago de Chile, Trinidad ${ }^{1}$. Het opsommen van de aangegeven begrenzing der gewesten heeft geen nut om den grooten omvang van het Spaansche gebied buiten Europa te overzien,

1 De namen der landvoogdijen, in dezelfde volgorde als de boven vermelde hoofdplaatsen, luiden: Isla Española, Nueva Espãna, Tierra Firme, Perú, Nueva España, Nueva Galicia, Nuevo Reino de Granada, de los Charcas, Perú, Filipinas, Chile, Puerto de Buenos Aires. - Nueva España en Perú waren dus later in twee deelen gesplitst. 
daar vele namen thans gewijzigd zijn. In het werk van A. E. NordenskiöLd, Periplus, Stockholm 1897, p. 163 vindt men een kaart «della parte del mondo novamente ritrovata van 1566, welke een denkbeeld geeft van het Amerikaansche Rijk van Spanje in dien tijd.

\section{§ 4. Provinciale Raden (Cabildos).}

Een belangrijke bestuursinstelling waren de "Cabildos" Raden, samengesteld uit personen, die hadden samen te werken tot regeling der zaken een geheele provincie dan wel onderdeelen daarvan betreffende. Onderscheiden benamingen treft men aan voor de waardigheidsbekleeders: corregidor, alcalde mayor, alcalde ordinario, alférez real, procurador, procurador general, regidor en oidor. De Leyes de Indias geven geen omschrijving van de aan elk dezer titels toekomende bevoegdheden. Vermoedelijk werden zij als bekend verondersteld, op grond ran hetgeen in het moederland bestond. De werkkring van de "Cabildos" is ook niet nader omschreven.

In 1625 werd aan de koloniale steden toegestaan om personen af te vaardigen die bij den Koning de belangen zouden kunnen voorstaan. Dergelijke opdracht mocht echter aan sommige ambtenaren niet worden verleend.

\section{§ 5. Regeling in latere tijden.}

De omschrijving der bevoegdheden van de koloniale landvoogden in de latere tijden vindt men nedergelegd in de Koninklijke decreten van 9 Juni en 8 November 1878. Zij komen in hoofdzaak overeen met hetgeen in het Regeerings Reglement van Ned. Indië is opgenomen. Als bijzonderheid geldt alleen, dat in de Spaansche koloniën de landvoogden, krachtens Pauselijke beslissingen en hiermede verband houdende wetten van het Koninkrijk, ook het patronaat uitoefenden over den Katholieken eeredienst. $\mathrm{Zij}$ werden ter zijde gestaan door een Raad, bestaande uit den hoogsten priester, den legerkommandant, den op dezen volgenden opperofficier, en de hoofden der departementen van justitie, financiën en binnenlandsch bestuur, alsmede den procureur generaal (Junta de autoridades superiores). Dit noodig cordeelende, kon de landvoogd voor een bepaald onderwerp ook den provincialen gouverneur in den Raad doen Dl. 79. 
zitting nemen. De Raad had een adviseerend karakter. De beslissing berustte bij den landvoogd, die in elk geval verantwoordelijk bleef tegenover het opperbestuur. Hij was verplicht de beslissing en de voorafgaande beraadslaging ter kennis te brengen van den minister van koloniën (de Ultramar) en van andere ministers, indien het onderwerp hun departement betrof.

Aan het hoofd der koloniale provinciën stond een gouverneur met een Raad (Consejo de administración). De gouverneur was burger. In de Filipijnen berustte echter tot 1886 de bevoegdheid in militaire handen. Ook daarna nog in sommige provinciën.

Krachtens een koninklijk decreet van 26 November 1880 werd Fernando Póo (West-Afrika) bestuurd door een militair, tevens belast met het beheer van het maritiem etablissement. De hem ter zijde staande Raad is samengesteld uit den gouvernementssecretaris, bepaaldelijk voor rechtszaken, den havenmeester, die den gouverneur waar noodig vervangt, den hoogsten geestelijke en den rechter.

De thans sedert het koninklijk decreet van 11 Juli 1904 geldende regeling omschrijft het Spaansch territoir ter Westkust van Afrika als: "Territorios españoles del Golfo de Guinea» en verdeelt het in Fernando Póo, Bata, Elobey en Annobón. ${ }^{1}$ Het bestuur berust thans in handen van een Gouverneur-Generaal, benoemd door den Koning, op voordracht van den Minister van Buitenlandsche Zaken (Ministerio de Estado) in overleg met den Ministerraad, met een raadgevend lichaam, bestaande uit den gouvernements-secretaris, den overste der zendingsvereenigingen, die door den Staat gesteund worden, den rechter van eerste instantie, den administrateur van financiën, het hoofd van openbare werken, den hoogsten in rang van de aanwezige officieren van zee- en landmacht. Naast voormelden Raad bestaan nog Raden tot bevordering van den gezondheidstoestand, tot verbetering van den landbouw, tot bescherming van de inboorlingen, en andere, betrekking hebbende op verschillende diensttakken.

1 De hier vermelde bijzonderheden zijn ontleend aan het werk van Louis Ramon-Izquierdo y Vivar: Descripoión geográfica y gobierno, administración y colonización de las colonias españolas del Golfo de Guinea. (Madrid 1912.) 


\section{Rechtspraak, Gevangenissen, Politie en Notariaat.}

\section{$\S 1$. Rechtspraak.}

Aanvankelijk vormde het rechtswezen geen op zich zelf staand geheel, doch was het verbonden aan het bestuur. Eerst lang. zamerhand wikkelde het zich los, al bleef nog lang het voorzitterschap der hoogere rechtscolleges in handen der hoogste bestuursambtenaren.

De rechters hadden met den meesten spoed hun ambt te aanvaarden, vooral op de plaatsen waar een onderkoning gevestigd was; uiterlijk binnen zes maanden na de benoeming ${ }^{1}$.

Vóór hun vertrek van de eene standplaats naar de andere, waren zij verplicht de loopende verrichtingen ten einde te brengen. Bleek dit onmogelijk door naderend vertrek, dan hadden zij een ander te machtigen om zoo noodig rekenschap te geven van de wijze waarop zij zich van hunne verplichtingen kweten.

De rechterlijke ambtenaren hadden ambtswoningen, dan wel vergoeding bij het gemis hiervan, en mochten niet meer dan vier slaven of slavinnen houden. Hunne vrouwen hadden zich te onthouden van inmenging in alle zaken.

In het maatschappelijk verkeer viel zekere beperking in acht te nemen (bl. 111). O. a. mocht in het eigen ressort geen huwelijk worden aangegaan. Dit verbod gold ook voor de kinderen.

Gewoonlijk werden de rechters aangeduid als oidores, (letterlijk: hoorders); die in strafzaken als "alcaldes del crimen.» Deze laatsten konden echter ook in burgerlijke zaken recht doen, wanneer de oidores met werk overstelpt waren. Dit werd door de landvoogden beslist.

De bevoegdheid bestond om rechters-commissarissen naar andere plaatsen te zenden voor het onderzoek van strafzaken. In het bijzonder hadden de landvoogden en presidenten der rechtbanken het recht om aan rechters-commissarissen een onderzoek op te dragen naar ambtelijke handelingen.

In geschillen over de vraag of eenig recht toekomt aan inboorlingen, dan wel aan niet-inboorlingen, behoorden de rechtbanken de getuigenverklaringen met de overige processtukken aan den Raad van Indië ter beslissing te zenden. De rechter

1 Deze termijn hield blijkbaar verband met de groote afstanden en de onzekere vervoermiddelen. 
was verplicht om ingeval van eigenrichting der tegenpartij de inboorlingen in hun vorigen toestand te herstellen. Later, in 1609 , werd de tusschenkomst van den Raad van Indië beperkt tot zaken eene waarde van 1000 dukaten vertegenwoordigende. Beneden dit bedrag, was de gewone rechter tot afdoening bevoegd.

De onderkoningen en andere hoogste bestuurders moesten in het moederland terechtstaan. De rechterlijke ambtenaren werden in strafzaken berecht door den onderkoning; gold het eene halszaak, dan werden zij met de processtukken aan den Raad van Indië opgezonden.

Voor de strafzaken was in sommige gewesten eene afzonderlijke Kamer waarin zitting hadden vier "alcaldes del crimen". Behalve waar het gold misdrijven waartegen de dood of eenige verminkende of andere lichaamsstraf was bedreigd, kon de uitspraak door twee hunner geschieden. In de laatst bedoelde gevallen waren voor de veroordeeling drie stemmen vereischt. Ingeval van nood, konden de strafrechters ook belast worden met de afdoening van burgerlijke zaken. Strafzaken tegen inboorlingen waren aan hunne kennisneming onttrokken. De alcaldes del crimen hadden het recht den Koning te schrijven buiten den landvoogd om. Deze laatste had hen altijd te woord te staan, wanneer zij dit wenschten. Van hunne zijde hadden zij den landvoogd op de hoogte te houden van de zich voordoende strafzaken.

Strafzaken tegen inboorlingen moesten met spoed en korte voorloopige hechtenis worden afgedaan. Het toebrengen van slagen met de hand en het toevoegen van beleedigende woorden onderling moesten onvervolgd blijven. Men had echter het mogelijke te doen om de vrede tusschen de strijdenden te herstellen. De bevoegdheid aan den landvoogd toegekend om in geschillen tusschen inboorlingen op te treden, komt verder ook toe aan de hoogste plaatselijke autoriteiten.

De landvoogden mochten zich, behalve wanneer uitdrukkelijk anders bepaald was, niet inlaten met rechtszaken, en waren verplicht den rechter geheel vrij te laten in zijne uitspraken (1603 en later). Meende de landvoogd dat de rechter zijne bevoegdheid te buiten was gegaan, dan moest hiervan den Koning verslag worden gegeven met mededeeling hiervan aan den rechter.

Voor de beslissing in juridictiegeschillen was in sommige 
gevallen de medewerking van den landvoogd noodig. Eene bijzondere bepaling gold sedert 1622 bij juridictiegeschillen tusschen de rechtsmacht der Casa de Contratación te Sevilla en den gewonen rechter aldaar. In dit geval had eene bespreking plaats van ieder der twee oudste rechters. Konden zij niet tot overeenstemming komen, dan moest de Koninklijke beslissing worden ingeroepen onder overlegging van stukken en van de wederzijdsche adviezen. Voor deze beslissing riep de Koning bijeen de voorzitters van den Raad van Kastilië en van den Raad van Indië, benevens twee leden uit iederen Raad.

Vorderingen beneden 20 pesos $^{1}$ waren in 1563 niet vatbaar voor rechterlijke beslissing. Later werd dit bedrag teruggebracht tot 6 pesos. Uitspraken over sommen beneden 200 pesos waren niet vatbaar voor hooger beroep. Na een vonnis in appèl, was geen verder beroep toegelaten dan op den Koning, wanneer de uitspraak zeer hooge bedragen betrof. Dadingen moesten uitgevoerd worden volgens de wetten van het moederland.

Uitspraken van de Casa de Contratación tot een bedrag van 10.000 maravedis waren voor dadelijke ten uitvoerlegging vatbaar. Beslaglegging was alleen toegelaten in de gevallen in de wet vermeld.

W raking van rechters moest behandeld worden op de wijze door de desbetreffende ordonnancies van Madrid in 1502 afgekondigd, met toepassing van de daarin voorkomende geldboeten bij ongegrondbevinding.

Hooger beroep in burgerlijke zaken, loopende over 600.000 maravedis en meer, behandeld door de Casa de Contratación, was toegelaten op den Raad van Indië, tenzij partijen vooraf de verklaring aflegden voor den griffier, van appel te willen afzien. Meende de Casa de Contratación in eenig geval partijen niet tot het beroep op den Raad te moeten toelaten, dan had zij de redenen hiervan in geschrifte neder te leggen.

Burgerlijke zaken op de Canarische eilanden kwamen in appel bij den daartoe aangewezen rechter op die eilanden, wanneer het bedrag in geschil niet meer bedroeg dan 40.000 maravedis. Anders bij de Casa de Contratación.

Gold het strafzaken, waarin opgelegd waren de doodstraf, eene verminkende straf, of eenige andere lijfstraf, dan wel altijd-

1 De peso was een zilveren munt van 1 ons gewicht $=8$ zilveren realen. 
durende verbanning, dan behoorde het beroep bij den Raad van Indië. Zoo ook, indien de eerste uitspraak afkomstig was van den met het onderzoek van ambtelijke verrichtingen belasten rechter (juez de residencia).

Administratieve beslissingen door de gemeente- en provinciale besturen genomen (ayuntamientos en diputaciones) konden dadelijk ten uitvoer gelegd worden, tenzij het te innen bedrag meer dan 60.000 maravedis beliep, in welk geval appel op den gewonen rechter openstond.

Beslissingen van den landvoogd waren onderworpen aan hooger beroep bij den hoogsten rechter in de residentie van den landvoogd.

Een tweede hooger beroep stond in sommige gevallen op den Koning open, segunda suplicación genaamd. Dan n.l. wanneer het bedrag in lite 6000 pesos van 450 maravedis of meer beliep. De tenuitvoerlegging werd door dit tweede'beroep niet opgeschort, behoudens zekerheidstelling voor teruggave van het voldane, indien de latere uitspraak dit medebracht. Het tweede beroep was uitgesloten, indien het geding liep over bezitrecht. Ook indien het eerste beroep eene uitspraak betrof van het administratief gezag of van den hoogsten rechter.

Het tweede beroep werd in werkelijkheid berecht door den Raad van Indië, met minstens vijf leden. Indien omstandigheden dit noodig maakten, konden desnoods vier leden uitspraak doen. In 1620 werd eene geldboete van 1000 dukaten bedreigd, indien het tweede beroep ongegrond bleek. Van deze som kwam $\frac{1}{3}$ aan de schatkist, $\frac{1}{3}$ aan de in het gelijk gestelde tegenpartij en $\frac{1}{3}$ aan de rechters die het eerste beroep behandeld hadden. Werd dadelijk uitgemaakt dat het tweede beroep niet ontvankelijk was, dan bedroeg de boete 400 dukaten, te verdeelen tusschen de schatkist en de tegenpartij.

Betreffende de tenuitvoerlegging van vonnissen verdient nog vermelding de verbodsbepaling om beslag te leggen op slaven en werktuigen bij de parelvisscherij benoodigd ${ }^{1}$; op inrichtingen voor metaalbewerking en suikerbereiding, in deze laatste gevallen behoudens het geval dat de schuld zóó groot was dat zij niet te dekken zou zijn door de geheele waarde dier inrichtingen met inbegrip der slaven, en de schuldenaar geen andere goederen

1 Men vergelijke hoofdstuk XXVI en bl. 173 van hoofdstuk XXV. 
had waarop de schuld te verhalen was. Het stond den schuldeischer alsdan vrij alles bijeen te doen verkoopen.

Paarden en wapens mochten alleen in beslag genomen worden, indien geen andere goederen aanwezig waren voor het verhaal der schuld.

In sommige gevallen mochten gekochte ambten bij executorialen verkoop overgaan op anderen, die tot de uitoefening geschikt werden geacht. Vooraf moest blijken dat geen goederen aanwezig waren waarop de schuld te verhalen was.

Van de waarde der geëxecuteerde goederen was $\frac{1}{10}$ verschuldigd aan de met de tenuitvoerlegging belaste personen, tenzij de betaling binnen de 72 (tevoren 24) uren geschiedde. Op enkele plaatsen was bovendien verschuldigd van $2 \frac{1}{2}$ tot $5 \%$ der opbrengst. De inboorlingen waren vrijgesteld van deze betalingen.

Aan den Fiskaal (het Openbaar Ministerie) was opgedragen beschermer te zijn van de inboorlingen en hen in alle zich voordoende gevallen voort te helpen en recht te doen verkrijgen, bepaaldelijk in burgerlijke rechtsgedingen en in strafzaken waarin de inboorlingen stonden tegenover Spanjaarden. Persoonlijk mocht hij niet handelen, dan wanneer de hulp van anderen tekort schoot. Ingeval de Fiskaal zelf tegen inboorlingen moest optreden in het belang van de schatkist, had de rechtbank iemand aan te wijzen om hunne belangen te behartigen. Gold het de uitgifte van gronden, dan was het wederom de Fiskaal, die voor de inboorlingen had op te komen. In het algemeen had hij te zorgen, dat hunne vrijheid niet werd aangetast, en dat zelfs tegenover slaven geen onrecht werd gepleegd.

In belangrijke zaken had de Fiskaal te overleggen met den onderkoning, den president of de rechtbank alvorens den Koning rapport uit te brengen over noodig geoordeelde maatregelen.

De Fiskalen in de koloniën hadden uitvoering te geven aan opdrachten van den Fiskaal van den Raad van Indië.

Voor de andere rechterlijke autoriteiten bestonden ook tal van voorschriften, mede met het oog op de onderlinge verhoudingen.

Vooral verdient aandacht hetgeen betrekking heeft op de advocaten. Als zoodanig mochten alleen optreden personen, die een examen hadden afgelegd in handen van president en leden der rechtbank. $\mathrm{Z}$ ij hadden een eed te doen om geen advies te geven in onrechtvaardige zaken en niet als honorarium te bedingen een aandeel in hetgeen hunne partij door het geding zou ver- 
krijgen. $Z_{\text {ij }}$ mochten niet optreden in zaken waarin een bloedof aanverwant als rechter zitting had. Hetgeen zij van de inboorlingen vorderden, moest zeer matig zijn.

De procureurs mochten eerst na aanstelling door den Koning optreden. Hun aantal was beperkt. De aanstelling werd voorafgegaan door een examen als voor de advocaten voorgeschreven. Voor beide categorieën was verboden het beding met partijen, dat het geding op hunne kosten zou worden gevoerd.

Bijzondere zorg valt te besteden aan de juiste keuze van tolken ten behoeve van de inboorlingen, zoowel wat betreft kennis der inheemsche talen als voor persoonlijke eigenschappen. Bij eenig verhoor door tusschenkomst van een tolk, mochten de inboorlingen zich doen vergezellen door een hunner christenvrienden, opdat deze kon vaststellen, dat de vertolking met juistheid geschiedde. De tolken mochten voor hunne bemoeienis niets vragen of aannemen van de inboorlingen.

\section{§ 2. Administratief gerechtelijk onderzoek.}

Om de drie jaren werd beurtelings een der rechters naar volgorde van benoeming eerst door de rechtbank, later door den voorzitter daarvan, afgevaardigd om in een aangewezen deel van het ressort een algemeen onderzoek in te stellen naar alle maatschappelijke instellingen in den uitgebreidsten zin, en naar de wijze waarop verschillende categorieën van personen behandeld werden en zich gedroegen. In het bijzonder had het onderzoek betrekking op de verspreiding der christelijke leer onder de inboorlingen, op hetgeen als belasting van hen gevorderd werd, en op de wijze waarop men hen bejegende. Ingeval van misbruiken, had de rechter het noodige te doen tot herstel van grieven, en tot bestraffing van de schuldigen. Tevens had hij te zorgen, dat de inboorlingen nuttige boomen aanplantten en arbeid verrichtten, dat hun ten voordeele kon zijn. Door Spanjaarden aangelegde werken, die voor inboorlingen schadelijk waren, moesten op last van den rechter, partijen gehoord, worden gewijzigd. Waar de rechter optrad in gevallen waarin de Kerk gemoeid was, had hij de kerkelijke rechtsmacht te eerbiedigen overeenkomstig het Kanonieke recht en de Koninklijke besluiten. Van alle bevindingen en genomen maatregelen werd door tusschenkomst van de rechtbank verslag uitgebracht aan den Raad van Indië. 


\section{§ 3. Latere rechtspraak.}

Uit den aard der zaak is in de latere jaren de afscheiding van rechterlijke macht en administratief gezag strenger doorgevoerd. Bij Kon. besluit van 30 Januari 1855 begon dit, en bij decreet van 26 October 1888 kwamen voor het rechtswezen op Cuba en Portorico nieuwe bepalingen tot stand.

Voor de administratieve rechtspraak kwamen in 1855 en 1861 andere voorschriften, die ook voor de Filipijnen golden, en in 1868,1875 en 1888 (13 September) werden vernieuwd.

In 1839 werd op de West-Indische eilanden met afschaffing van de voorloopige hechtenis voor kleine misdrijven, straf baar met 2 tot 6 maanden (voor negerslaven tot 1 jaar) tewerkstelling in het openbaar, eene verkorte berechting ingevoerd, terwijl de lijfsdwang ten hoogste 12 dagen mocht bedragen. In het volgende jaar kwamen nieuwe bepalingen betreffende de berechting van straf- en burgerlijke zaken.

In 1855 werd de rechterlijke organisatie voor Cuba, Portorico en de Filipijnen bij Koninklijk besluit herzien, met mogelijkheid tot het inroepen van eene eindbeslissing van de Kamer voor Koloniale Zaken (Sala de Indias) van het Opperrechterlijk College (Tribunal Supremo de Justicia) in het moederland. In het $7^{\mathrm{e}}$ hoofdstuk (art. 123 e. v.) leest men, dat alle rechterlijke betrekkingen, die van oudsher voor de meestbiedenden verkrijgbaar waren, voortaan alleen voor het leven van den kooper in openbare veiling zullen worden toegewezen. De vroeger toegewezenen zullen nog slechts eenmaal kunnen overgaan op een ander voor de helft van den oorspronkelijken toewijzingsprijs en behoudens de verkrijging van de Koninklijke goedkeuring binnen het jaar. Het lot had aan te wijzen welke ambten door den Staat konden worden teruggekocht, telkens wanneer de toestand der schatkist dit veroorloofde.

Merkwaardig is in 1858 op Cuba een maatregel tot tegengang van de vele roof- en moordgevallen door gewapende benden, die zich op het platteland voordeden, en dikwijls ongestraft moesten blijven. De oproeping n.l. van alle weerbare mannen, zoodra eenig misdrijf had plaats gehad, om de schuldigen op te sporen en aan de bevoegde autoriteit uit te leveren. Daartoe werd de alarmklok geluid ( «tocar á somatén»), dat in alle naburige ressorten herhaald werd: tien langzame slagen 
gedurende twee uren met tusschenruimten van 4 of 5 minuten. Alle mannen van 18 tot 50 jaar, met uitzondering van enkele categoriën, waren verplicht zich dadelijk gewapend samen te voegen op aangewezen plaatsen en de hun gegeven bevelen op te volgen. Alle eenigszins verdachte personen werden opgevat, zoo noodig met gebruikmaking van wapens, en in samenwerking met de politie te voet en te paard. Tegen het niet dadelijk handelen, waren geldboeten bedreigd.

\section{§ 4. Boedelreddering.}

Ten behoeve van de boedelreddering van in de koloniën overleden personen werd door den landvoogd als voorzitter der rechtbank een rechter-commissaris benoemd, aanvankelijk voor één jaar (1550), later voor twee jaren (1609). Het doel was om de misbruiken te voorkomen, die gepleegd werden ten opzichte van nalatenschappen. De rechter-commissaris trad ook op in boedels van geestelijken, en had vóor alles inventaris op te maken. De tot den boedel behoorende gelden en waardevolle voorwerpen werden afzonderlijk opgeborgen bij 's Lands kas en zoo noodig door tusschenkomst van den Raad van Indië naar het moederland gezonden. Op plaatsen waar geen landskas bestond, werd een bijzondere bergplaats toevertrouwd aan de zorg van drie personen, tevens met de boekhouding belast. Aan den landvoogd, den voorzitter der rechtbank en de ontvangers had de rechter-commissaris rekening en verantwoording te doen. Wanneer de erfgenamen zich bevonden ter plaatse waar de erflater overleden was, en deze een testament nagelaten en boedelredderaars aangewezen had, mocht de rechter-commissaris zich niet met den boedel inlaten. Hetzelfde gold, wanneer geen testament bestond, doch de erfgenamen ab intestato zich in persoon aanmeldden en van hunne erfgerechtigheid deden blijken. Bestond omtrent dit laatste onzekerheid, dan berustte de beslissing bij den gewonen rechter. Waren er geen erfgenamen, dan had de rechter-commissaris de nalatenschap aan den Staat toe te wijzen behoudens nadere uitspraak van den rechter, ook in verband met de mogelijkheid van later blijkende aanspraken.

De uitvoerders van uiterste willen, erfgenamen en houders van nalatenschappen, die deze geheel of ten deele hadden af te dragen aan in het moederland gevestigde personen, behoorden binnen het jaar de overdracht te doen geschieden door tusschen- 
komst van de Casa de Contratación. Kon deze termijn niet worden in acht genomen wegens gebrek aan scheepsgelegenheid of eenig ander vaststaand beletsel, dan moest de afgifte met de rekening en verantwoording geschieden aan den rechter-commissaris. Tenzij de erflater anders beschikt had, mochten voormelde personen de nalatenschap niet langer dan een jaar onder zich houden op straffe van vergoeding van kosten, schade en interessen, alsmede verplichting om het dubbele der waarde uit te keeren. Van dit dubbele kwam dan de helft aan de schatkist, en de andere helft aan de erfgenamen.

De verplichting tot opzending van de nalatenschap naar Sevilla bestond ook, indien in de koloniën geen erfgenamen te vinden waren, behoudens voorafgaande voldoening van vaststaande boedelschulden.

De testamenten, inventarissen en andere boedelpapieren behoorden met afzonderlijke scheepsgelegenheid naar Sevilla te worden gezonden.

Verkoop van tot nalatenschappen behoorende goederen moest voorafgegaan worden door taxatie en op voorgeschreven wijze geschieden.

Voor sommige koloniën was omzetting der waarden in aangegeven koopwaren voorgeschreven.

\section{§ 5. Gevangenissen.}

Gevangenissen waren reeds in 1578 voor alle plaatsen voorgeschreven, met dien verstande dat de vrouwen zorgvuldig van de mannen afgescheiden moesten zijn, en dat voor allen gelegenheid bleef bestaan om de mis bij te wonen. De cipiers hadden een plechtigen eed af te leggen, en mochten de sleutels niet in handen stellen van inboorlingen en slaven. $\mathrm{Zij}$ hadden te zorgen voor reinheid en voor goede behandeling van de gevangenen, met inachtneming van stand en rang. Geen spelen mochten plaats hebben.

De gevangenissen moesten eens in de week door twee rechters en het Openbaar Ministerie worden bezocht, en bovendien op groote kerkelijke feestdagen. In het bijzonder moest achtgeslagen worden op gegijzelden.

\section{§6. Politie.}

Deze was ingericht op den voet als in het moederland gebruikelijk. $\mathrm{Zij}$ werd n.l. uitgeoefend door broederschappen (h e rmandades). 
Aan het hoofd stonden de alguaciles, onderscheiden in mayores en menores (de laatsten echter niet ondergeschikt aan de eersten), met hunne plaatsvervangers, en alcaides, meer in het bijzonder toezicht houdende over de gevangenissen. In plaatsen, voornamelijk bewoond door inboorlingen, mocht sedert 1631 een hunner door den corregidor tot alguacil worden aangesteld. Aan allen was verboden het aannemen van geschenken.

\section{§ 7. Notariaat.}

Het notariaat werd aanvankelijk uitgeoefend door «escribanos reales", daartoe benoemd door den landvoogd of door lagere autoriteiten. In 1564 en later kwamen bepalingen, dat door den Koning of den Raad van Indië personen zouden worden aangewezen, voor het opmaken van acten, en wel alleen $z \mathrm{ij}$, die tot uitoefening van het notariaat bevoegd waren, behoudens tijdelijke benoemingen door de landvoogden of plaatselijke bestuurders.

Sedert 1610 waren de notarieele examens opgedragen aan de koloniale rechtbanken.

Het verhoor van getuigen, die niet voor den rechter konden verschijnen, mocht worden opgedragen aan een "escribano» der. woonplaats.

Tot "escribanos» of notarissen (notários públicos) mochten geen personen van halven bloede (mestiezen of mulatten) worden benoemd.

De titel van "escribano» werd ook gevoerd door hen, die als griffiers optraden bij de verschillende autoriteiten.

De griffiers bij geestelijke autoriteiten voerden - evenals nu nog - den titel van "notario eclesiástico of apostólico», en moesten leken zijn.

\section{Mijnwezen, ${ }^{1}$}

\section{§1. Metaalwinning.}

Karel I (V) in 1526 en Filips II in 1568 stonden aan alle Spanjaarden en inboorlingen, behalve aan landsdienaren, toe om goud, zilver, kwik, lood, tin, ijzer enz. uit door hen ontdekte mijnen en uit rivieren, ravijnen en overige vindplaatsen door

\footnotetext{
1 Men vergelijke hierbij hoofdstuk XVII § 5 .
} 
hunne dienaren en slaven te doen ontginnen, en vrijelijk te bewerken, zonder eenig beletsel. $\mathrm{Z}$ ij hadden alleen het betrokken bestuurshoofd te verwittigen en de belofte af te leggen, dat zij na het omsmelten persoonlijk van de resultaten rapport zouden uitbrengen. Op het ontdekken van mijnen werden premies gesteld, waarvan $\frac{2}{3}$ te voldoen door de schatkist en $\frac{1}{3}$ door den ontginner. Deze premies golden in het bijzonder voor de kwikmijnen.

Mijnen, die vier maanden achtereen onbewerkt gelaten werden, konden door den landvoogd toegewezen worden aan hen, die zich daartoe aanmeldden, en bereid bleken gestelde voorwaarden te aanvaarden. Voor geregelden aanvoer van levensmiddelen moest worden gezorgd. Aan inheemsche werklieden was een billijk loon verschuldigd.

In 1608 werd gewag gemaakt van kopermijnen op Cuba. Dat het koper groote waarde had voor de artillerie, blijkt uit voorschriften voor de wijze van smelting en den overvoer naar de Casa de Contratación op landskosten.

Verkoop van metalen was sedert 1617 alleen aan de mijneigenaren veroorloofd.

Inboorlingen, die een mijn ontdekten, moesten door premies, belooningen en beloften van belastingvrijstelling worden overgehaald om tot ontginning over te gaan. Spanjaarden en hunne afstammelingen, ook mestiezen en mulatten, werden door belooningen van anderen aard aangemoedigd. Overigens bestond in het toekennen van rechten geen onderscheid tusschen Spanjaarden en inboorlingen.

Ten behoeve van den goeden gang van zaken in de mijnen kwam in 1572 het later herhaald voorschrift, dat de mijneigenaren zelfs voor schulden in hun bedrijf niet mochten worden gestoord door beslaglegging op slaven en negers, op werktuigen en andere voorwerpen voor het te voorschijn brengen van metalen benoodigd. ${ }^{1}$ Alleen op het reeds verkregen goud of zilver mochten schuldvorderingen verhaald worden. Was in gijzelingstelling onvermijdelijk, dan mocht deze alleen geschieden ter plaatse waar de zetel was van het mijnwerk, opdat dit werk niet te lijden zou hebben. Benoodigdheden voor de mijnen konden voor billijken prijs betrokken worden uit 's lands voorraad. Geschillen waarin

1 Vergelijk bl. 166 onderaan. 
mijneigenaren betrokken waren, moesten met den meesten spoed beëindigd worden. Ook op de Filipijnen golden sedert 1635 deze bepalingen.

Bij wijze van uitzondering mochten mijneigenaren op sommige plaatsen met ambten belast worden, zelfs al waren zij gelden verschuldigd aan het land.

Tot handhaving van orde en recht in de mijnen waren "alcaldes mayores" aangesteld, aan wie onder strafbedreiging verboden was voor zich of voor anderen in de mijnen goud, zilver of andere metalen te koopen. $\mathrm{Zij}$ mochten evenmin, en dit gold ook voor andere met mijnzaken belaste ambtenaren, middellijk of onmiddellijk belang hebben bij de opbrengsten der mijnen. De ambtelijke bezoldigingen werden niettemin uit de mijnkassen gekweten.

Het uit de mijnen verkregen metaal moest met inachtneming van formaliteiten in bepaalde vormen gebracht worden met vaststelling der waarde op zichtbare wijze daarop. De in waarde verschillende soorten werden op onderscheiden wijzen behandeld, en van alle verrichtingen ter zake dienden getuigschriften te worden opgemaakt. ${ }^{1}$ Aan de schatkist was een vijfde gedeelte der gewonnen metalen verschuldigd, alsmede $1 \frac{1}{2} \%$ der waarde van het geheel. ${ }^{2} \mathrm{Bij}$ de smelting, voorafgegaan door weging der ertsen, waren landsdienaren tegenwoordig, die daarvan boek hielden. Zoo ook bij de waardebepaling en het daarmede verband houdende merken. Voor een en ander bestonden uitvoerige instructies.

\section{§ 2. Aanmunting van geldstukken.}

Sedert 1535 waren er drie munten van edele metalen, voornamelijk zilver, en wel te Mexico, Santa Fé en Potosí. De andere geldstukken werden te Santo Domingo vervaardigd. Van het aangemunte geld, dat geheel gelijk moest zijn aan dat in het moederland, was een klein bedrag aan de schatkist verschuldigd. Daling der metaalwaarde kwam voor rekening van de aanmunters. Het munten stond onder ambtelijk toezicht. De met muntwerkzaamheden belaste personen moesten tot de bekwaamsten in hun vak behooren. Met inachtneming hier-

1 Ook de parels en edelgesteenten moesten op bepaalde wijze gewaarmerkt zijn. Bleek dit niet mogelijk, dan werd de waarde door schatting vastgesteld.

? Dit gold ook voor parels, edelsteenen en amber. 
van, werden de ambten echter aan de meest biedenden verkocht. Op hen rustte het verbod om zich in de uitoefening van hun ambt door anderen te doen vervangen dan met toestemming van de hoogste autoriteiten, om in zilver handel te drijven, en om op eigen gezag zilver aan te munten; overtredingen waren met zware straffen bedreigd. Van sommige belastingen waren zij vrijgesteld; rechtsvorderingen tegen hen behoorden tot de bevoegdheid van de met het toezicht op het munten belaste personen. Gold het evenwel vorderingen ten behoeve van de schatkist, dan berustte de uitspraak bij den gewonen rechter.

In verband met den aanmaak van gemunt geld, werd reeds in 1591 het gebruik van ongemunt goud en zilver als ruilmiddel verboden. Het in de koloniën gemunte geld moest over en weer in de koloniën en ook in het moederland worden gebruikt tegen een vastgestelden koers. Uitvoer naar vreemde landen stond echter niet vrij.

Ter voorkoming van bedrog mochten edele metalen door particulieren niet van het eene gebied naar het andere worden vervoerd, noch ook naar het moederland. De voor de schatkist ingeleverde hoeveelheden moesten sedert 1631 in natura naar het moederland worden gezonden, zoo ook het koper, dat vór alles bestemd was voor kanonnen en ander oorlogsmateriaal.

Met de zorg voor de edele metalen, parels en edelgesteenten uit de koloniën voor den Staat dan wel voor particulieren aangevoerd, waren in 1605 en volgende jaren belast "maestres de plata» (zilverbeheerders), die 25.000 dukaten zekerheid hadden te stellen, en geen merma (spillage) in rekening mochten brengen. $\mathrm{Z}_{\mathrm{ij}}$ hadden echter recht op $1 \%$ der waarde, waarvan uit de voorgeschreven registers diende te blijken.

Ook over de andere lading waren maestres de navios aangesteld, die slechts tot 10.000 dukaten zekerheid verplicht waren. $Z_{\text {ij }}$ moesten met de scheepskapiteins samenwerken om de tucht aan boord te onderhouden, het vloeken en het hazardspel tegen te gaan. Bleek bij stormweer het in zee werpen van een deel der lading noodig, dan hielden beiden met de bemanning en de passagiers scheepsraad. Oorlogstuig en munitie mochten niet geworpen worden. 


\section{Parelvisscherij. ${ }^{1}$}

Ter bevordering van de parelvisscherij was bekendmaking van de vindplaatsen aan de plaatselijke autoriteit voorgeschreven. Het doel was om geschikte woningen, bergplaatsen enz. op te richten, zoowel voor Spanjaarden als voor inboorlingen en slaven, en om overigens aan het hoofd der op deze wijze ontstane vestigingen de noodige ambtenaren te stellen, die o. m. te waken hadden tegen zeeroovers. Aan de schatkist waren de ontdekkers $1 / 10$ van de in den aanvang gevonden parels verschuldigd; gedurende de volgende drie jaren moest $1 / 5$ worden opgebracht.

De inboorlingen mochten niet belemmerd worden in de parelvisscherij, mits zij aan den Staat $1 / 5$ afstonden, en zich overigens naar de voorschriften gedroegen. Hadden Spanjaarden bij de uitoefening van hun bedrijf hulp noodig, dan mochten alleen negers daartoe gebezigd worden, geen inboorlingen.

Tal van administratieve bepalingen regelen verder de zaak, o. a. dat niet meer oesterschelpen boven water mogen worden gebracht dan men dadelijk kan bewerken, daar anders de uitwaseming ziekten zou kunnen veroorzaken. Ook was het aan wal brengen niet veroorloofd dan in tegenwoordigheid van de daarvoor aangestelde ambtenaren en rechthebbenden. Bij het binnentreden van de voor de bewerking bestemde lokalen moesten de dragers geheel ontkleed zijn. De voor den Koning bestemde parels werden in een afzonderlijke kist opgeborgen en met de meeste zorg verpakt en verzegeld voor de verzending naar Europa. De sleutel was af te geven aan den vlootbevelhebber met de overbrenging belast.

Ook voor de verschillende parelsoorten waren afgescheiden bergplaatsen.

\section{Fabriekswezen.}

In 1628 verbood Filips IV de oprichting van groote werkplaatsen en fabrieken zonder zijne toestemming. Deze was alleen te verkrijgen, indien door tusschenkomst van den Raad van Indië de noodzakelijkheid en de grondslagen waren aangetoond. Aanleiding tot deze bepaling waren de misbruiken, die in de weverijen van linnen en andere stoffen voorkwamen, en waarvan vooral de inboorlingen slachtoffers waren, niettegenstaande in 1621 met het oog op dit laatste maatregelen werden voorgeschreven.

1 Men vergelijke bl. 166. 
Overigens vindt men reeds in 1565 gewag gemaakt van linnenweverijen, voor welke de in het moederland geldende bepalingen van kracht zouden zijn.

Aan het verbod van 1628 gingen vooraf bepalingen van 1612 en 1624 , waarin ook geklaagd wordt over de slechte behandeling van inboorlingen, en tevens over den invoer uit Mexico in Peru van geweven stoffen, waardoor de handel met het moederland benadeeld werd. Met het oog hierop ging de last aan den onderkoning van Mexico (Nueva España) om zooveel mogelijk de inboorlingen aan de weverijen te onttrekken, en tevens in het belang van den moederlandschen handel de uitvoer van geweven stoffen naar Peru te verbieden (bl. 182).

In 1548 was uitdrukkelijk toegestaan om in Los Angeles, destijds behoorende tot Mexico (Nueva España), zonder eenige belemmering zijdeweverijen op te richten.

\section{Inheemsche gemeenschapsinstellingen en gemeen- schappelijke pakhuizen (pósitos en alhóndigas).}

\section{$\S 1$. Gemeenschapskassen.}

Goederen, aan de inboorlingen van eene gemeente gemeenschappelijk toebehoorende, werden in daartoe bestemde kassen bijeengebracht en van daaruit beheerd. Deze kassen werden aangeduid als "cajas de censos" dan wel als "bienes de comunidad, en bestonden reeds in 1561. Voor de rentegevende uitzetting, de boekhouding en de wijze van beheer bestonden regels, op de nakoming waarvoor ambtelijk toezicht werd uitgeoefend. Jaarlijks moest verantwoording worden gedaan aan een daartoe aangewezen rechter-commissaris, zoo noodig met beroep op de geheele rechtbank, indien aangaande het beheer geschillen rezen. De rechter-commissaris had die intusschen voorloopig te beslissen. De Fiskaal vertegenwoordigde de belangen der kassen in rechten. In vervolg van tijd werden van Staatswege verschillende beambten voor de werkzaamheden benoemd.

Gezorgd moest worden voor de aanwezigheid van een voldoend bedrag, waaruit zoo noodig te voorzien was in de zich voordoende behoeften der gemeenschap of der rechthebbenden individueel.

De administratie van deze kassen moest geheel afgescheiden blijven van elk ander beheer, en behoorde te allen tijde uitsluitend ten bate van de inboorlingen te blijven. Geen enkel Dl. 79 . 
ander persoon mocht, onder welken titel ook, uit deze kassen geld of goederen ter leen of ten gebruike krijgen op straffe van vier malen de waarde. Uit de renten werden de belastingen betaald, terwijl hetgeen voor andere uitgaven noodig voorkwam, door een daartoe aangewezen ambtenaar werd begroot. Deze had vooral te waken, dat de leden der gemeenschap niet meer ontvingen dan zij behoefden, teneinde lediggang te voorkomen. Uit de kassen was ook met machtiging van den landvoogd of andere hooge autoriteit te betrekken wat vereischt werd voor uitgaven ten behoeve van den godsdienst, in het bijzonder voor de zending, de opleiding daartoe van zonen der oudsten, en voor de gevangenissen. Alles moest op zuinige wijze geschieden, ter vermijding van benadeeling der inboorlingen. Bepaaldelijk was uitgesloten, dat uitgaven van anderen aard uit de kassen gekweten werden, zooals weleens was voorgekomen bij den aankoop van schilderijen en het geven van maaltijden en feesten. Het kapitaal moest in elk geval bijeengehouden worden, zoodat alleen de renten verbruikt werden.

In 1582 werd aan de deelhebbers der gemeenschappelijke kassen opgedragen om jaarlijks zekere uitgestrektheid grond (10 brazas) met koren te beplanten in plaats van de kleine bijdrage ( $1 \frac{1}{2}$ reaal) anders aan de kassen verschuldigd. De oudsten waren van deze verplichting ten deele vrijgesteld.

In 1615 bleek het noodig om de onderkoningen en andere hoogwaardigheidsbekleeders op het hart te drukken te waken tegen de misbruiken van de corregidores van inlandsche gemeenten, die door het vorderen van werkzaamheden voor hunne particuliere ondernemingen de inboorlingen aan hun eigen werk onttrokken, waardoor steun uit de gemeenschapskassen noodig werd. In 1621 was niettemin de toestand zóó erg geworden, dat zelfs de doodstraf bedreigd werd. Eenige jaren later (1636) werd een jaarlijksch rapport aan den Koning geëischt van alle maatregelen in het belang der gemeenschappelijke kassen, terwijl in 1668 het bevel kwam om alle achterstallige schulden aan die kassen met kracht te innen en daarin te storten, ook die ten behoeve van 's Lands dienst aangegaan.

\section{§ 2. Gemeenschappelijke weideplaatsen enz.}

Het gemeenschapsbegrip bestond ook ten aanzien van sommige weideplaatsen. In 1541 werden mede tot gemeenschappelijk 
eigendom van de in de omgeving wonenden verklaard de bergen en het bevloeiingswater, voor welks gelijkmatige verdeeling moest worden gezorgd.

\section{§ 3. Pósitos.}

In 1614 vindt men melding gemaakt van "pósitos», te omschrijven als in gemeenschappelijk eigendom toebehoorende graanpakhuizen, waaruit leeningen zijn te verkrijgen, onder verplichting tot terugstorting in natura bij den volgenden oogst. Deze 'pósitos» bestaan ook sedert eeuwen in Spanje, en komen overeen met de in Ned.-Indië nu ruim 20 jaren geleden in het leven geroepen edesa loemboengs, waarin met dezelfde bedoeling rijst ligt opgeschuurd.

\section{§ 4. Alhóndigas.}

Met de 'positos, hangen eenigszins samen de calhóndigas», zij het ook met eene andere bestemming. De met voormelden naam aangeduide pakhuizen van graan en meel hadden n.l. ten doel eensdeels om den opslag van geoogste granen gemakkelijk te maken; anderdeels om den koop en verkoop tegen matigen prijs in de hand te werken.

De aan het hoofd van deze inrichtingen staande personen, die 4000 pesos zekerheid hadden te stellen en in de inrichting moesten wonen, bepaalden dagelijks volgens vastgestelden maatstaf den prijs. $\mathrm{Zij}$ mochten uit hun magazijn noch voor zich zelf, noch door middel van anderen inkoopen doen.

Koop en verkoop van granen buiten de calhóndigas» was verboden op straffe van geldboeten.

De broodbakkers, die geen grooteren voorraad mochten opslaan dan voor twee dagen, kwamen eerst na de groote mis bij den verkoop aan de beurt, om de andere bewoners gelegenheid te geven voor te gaan.

De karrevoerders, die met graan en meel van buiten kwamen, waren verplicht tot dadelijke inlevering in de alhóndigas, en kregen daarvoor een bewijs dat op afvrage moest worden vertoond.

De verkoop van de opgeschuurde hoeveelheden duldde geen langer uitstel dan 20 dagen.

Toegang tot de pakhuizen was aan gewapenden verboden. Landbouwers, die tevens bakkers waren, mochten een deel 
van den oogst buiten de pakhuizen houden, doch hadden dan daarvan een jaarlijks te beëedigen opgave te doen.

Twee "regidores" waren beurtelings belast met de handhaving van de orde in de pakhuizen en met de beslissing van zich voordoende geschillen, behoudens beroep op eene hoogere autoriteit.

Van de in de pakhuizen binnengebrachte hoeveelheden was een vastgesteld bedrag als belasting verschuldigd.

\section{Beperkingen op het gebied van handel en scheepvaart.}

\section{$\S 1$. Filipijnen.}

Aanvankelijk mochten de Filipijnen alleen handel drijven met Nueva España (Mexico), en dan nog met beperkingen. De toelating van Chineezen en Japanners was met uitdrukkelijke toestemming van den landvoogd geoorloofd tot een aantal van hoogstens 6000 en 3000 (1606). $\mathrm{Zij}$ werden aangeduid als "Sangleyes, ${ }^{1}$.

Met Japan was de handel veroorloofd, met dien verstande dat later geen Japanners in de Filipijnen mochten komen (1609). Met China stond de handel in zooverre open, dat Chineesche schepen alleen te Manila mochten binnenloopen, en onderworpen waren aan onderzoek.

In het algemeen behoorde streng gewaakt te worden tegen de toelating van vreemdelingen. Schepen uit andere koloniën dan Nueva España aankomende, al was het ook met toestemming van den betrokken landvoogd, verloren hunne lading, terwijl de gezagvoerders gestraft werden met verbeurdverklaring van hunne bezittingen en tien jaren galei.

Naar Nueva España (Mexico) mochten jaarlijks niet meer dan twee schepen uit de Filipijnen vertrekken met eene waarde aan koopmanschappen van hoogstens 250.000 pesos van 8 realen. Voor eene dubbele waarde mocht worden teruggevoerd. Deze bedragen moesten gelijkmatig worden verdeeld onder de gegadigden door tusschenkomst van aangewezen autoriteiten.

1 De letterlijke beteekenis van Sangleyes heb ik niet kunnen rinden. Wellicht is het woord eene verbastering van "sin leyes" zonder wetten, hetgeen dan overeenkomt met onze uitdrukking "zonder wet en gebod" als aanduiding van vermeende minderwaardigheid. 
Uitvoer van bewerkt zilver naar de Filipijnen was verboden. $Z_{i j}$, die uit Nueva España naar de Filipijnen vertrokken met de bedoeling er minstens acht jaren te verblijven, mochten hunne bezittingen medenemen, mits zekerheid stellende.

De Portugeezen van Oost-Indië mochten geen handel drijven in de Filipijnen.

De tot het Christendom overgegane Chineezen, die gedurende 10 jaren vrij waren van belasting, mochten nitt naar hun land terugkeeren dan met toestemming van den landvoogd. Goede behandeling en vrijstelling van persoonlijke diensten waren voorgeschreven. Ook werd aangemoedigd het huwelijk met inheemsche vrouwen. Niettemin was het verblijf in Manila gedurende den nacht verboden.

De schepen tusschen de Filipijnen en Nueva España varende, hadden te zorgen in Maart in de Filipijnen aan te komen; zij moesten goed bewapend zijn, zonder vele manschappen mede te voeren. Elk kanon had niet meer dan één artillerist, die met de noodige eer behandeld moest worden. Graan mocht niet in de Filipijnen worden ingevoerd. Een getrouwde man werd zonder zijne vrouw uit Nueva España niet in de Filipijnen toegelaten, tenzij zij hare toestemming had gegeven en de man zekerheid had gesteld voor de terugkeer binnen den vastgestelden termijn, en voor haar onderhoud had gezorgd. Het vertrek uit Nueva España was, met het oog op de moesson, voorgeschreven in December om in Maart in de Filipijnen aan te komen. Van daar had het vertrek in Juni plaats. Geestelijken mochten niet over Oost-Indië naar het moederland reizen.

Voor den handel met China bestond het voorschrift, dat een jaarlijks te benoemen commissie van 2 of 3 deskundigen alle uit China aangebrachte koopwaren ineens moest opkoopen, om die onder de bewoners der Filipijnen weder te verkoopen op zoodanige wijze, dat allen gelijkelijk van de voordeelen kunnen genieten. Men noemde dit "Pancada». Van het verrichte werd boek gehouden en jaarlijks verslag gedaan aan den Raad van Indië. Op andere wijze was handel met China verboden. (1593).

Contrabande was op te zenden aan de Casa de Contratación om vandaar ter beschikking te komen van den Raad van Indië.

Ook op Macao, Malaka, Siam, Kambodja en andere omliggende streken mochten geen schepen uit de Filipijnen varen. 
De schepelingen hadden slechts het noodige aan kleeding mede te nemen. Aan de inboorlingen had men warm goed te verschaffen.

Uitvoer van slaven uit de Filipijnen was verboden. Alleen bepaalde autoriteiten mochten met goedkeuring van den gouverneur 6,4 of 2 slaven medenemen. Medeneming van slavinnen dan wel van getrouwde vrouwen was verboden.

De passagekosten mochten niet overdreven worden. Die voor de heen- en terugreis waren naar evenredigheid lager te stellen.

Als tusschenhaven vindt men Acapulco (Mexico) aangewezen voor het onderzoek of de voorschriften in acht zijn genomen, en voor de betaling van het recht van alcabala (bl. 189). Later was Mexico de plaats waar een Contador van den Tribunal de $\mathrm{Cu}$ entas en twee andere autoriteiten, jaarlijks aan te wijzen, de ladingwaarde hadden te bepalen. Van den handel tusschen de Filipijnen en Nueva España werd jaarlijks een rapport ingewacht bij den Raad van Indië.

Koopwaren uit China mochten niet naar Peru gaan, uit welken hoofde ook, onder bedreiging van zware straffen. Met het oog hierop was het aanloopen van Peruaansche schepen in Acapulco verboden.

De prelaten hadden te zorgen, dat geen Chineesche goederen in de kloosters verborgen werden.

Later werd ook de handel tusschen Peru en Nueva España verboden (bl. 177). Ambtenaren, die tusschen deze streken voeren, hadden een eed af te leggen, dat de goederen, die zij medenamen, hun eigendom waren en voor eigen gebruik dienden. Voorafgaande registratie was bovendien voorgeschreven.

\section{§2. West-Indische eilanden.}

Ook voor de West-Indische eilanden waren handel en scheepvaart aan banden gelegd, met verbeurdverklaring van schip en lading ingeval van overtreding der voorschriften.

Ten aanzien van den handel in landbouwproducten verdienen nog vermelding de volgende bepalingen.

De op sommige eilanden geoogste tabak mocht, voor zooveel niet ter plaatse benoodigd, sedert 1614 te Sevilla ${ }^{1}$ worden aan-

1 Ook thans is nog te Sevilla de grootste staatsfabriek tot verwerking van tabak gevestigd. 
gebracht, ten einde de daarop te behalen winsten in de schatkist te doen vloeien.

Ook de wol moest zooveel mogelijk in het moederland worden verhandeld.

Voortbrengselen als wijn, meel en verdere voedingsmiddelen waren bij invoer aldaar aan inkomend recht onderhevig.

Tusschen de koloniën mocht invoer van levensmiddelen zonder eenige heffing geschieden, met enkele uitzonderingen, zoo bijv. van wijn uit Peru naar Panamá. Te Panamá mocht geen wijn worden verkocht; evenmin tabak.

Cochinilla en bewerkingen daarvan mochten door inboorlingen worden ingevoerd. Zoo ook huiden, die te Sevilla werden gelooid.

Aanplant en bewerking van vezelstoffen werd in de hand gewerkt.

Maten en gewichten waren als in het moederland.

\section{Rekenplichtigheid.}

In 1605 gelastte Filips III de instelling van drie Tribunales de contadores, welke benaming in het Nederlandsch het best weer te geven is door die van Algemeene Rekenkamers. Een in de stad de los Reyes voor de provincies van Peru, de tweede in Santa Fé voor Nieuw Granada, de derde in Mexico voor Nueva España. ${ }^{1}$ Later werden voor Venezuela, Cuba en andere West-Indische eilanden bepalingen gemaakt, krachtens welke comptabele stukken dadelijk naar den Raad van Indië moesten gaan, terwijl die van Honduras en Guatemala naar Mexico werden gezonden. In de latere tijden hadden Cuba, Portorico en de Filipijnen afzonderlijke Rekenkamers, bestaande uit een president, twee leden, een fiskaal, een algemeene secretaris en verder personeel,

Elk der eerstvermelde lichamen was samengesteld uit drie "contadores de cuentas", twee "contadores de resultas» en twee andere ambtenaren met verschillende titels door den Koning te bepalen ("oficiales con titulos nuestros») allen belast met het onderzoek der verantwoording van rekenplichtigen.

Zij hadden den eed van trouw af te leggen in den Raad van Indië te Sevilla, dan wel in handen van den betrokken onderkoning of van den voorzitter der rechtbank.

1 Voor Potosi was eene afzonderlijke regeling getroffen, n.l. eene driejaarlijksche kasopneming door een der contadores de cuentas te Lima. 
In evengemeld jaar en later werden tal van voorschriften afgekondigd over de administratie, de boekhouding, het verifieeren der rekeningen en der kassen, alsmede de wijze waarop dit geschieden moest. Dit alles in bijzonderheden te vermelden heeft geen nut.

Jaarlijks moesten de inkomsten en uitgaven worden vastgesteld, ${ }^{1}$ met vermelding van hetgeen nog te innen of te voldoen bleef, zoodat de Raad van Indië, door welks tusschenkomst bij de eerste scheepsgelegenheid de stukken werden ingediend, een volkomen juist ovierzicht kon verkrijgen van den stand der financiën. Het spreekt van zelf, dat de rekenplichtige ambtenaren in verband hiermede aan termijnen en modellen gebonden waren.

In 1627 kwam de bepaling, dat geschillen over de ingediende rekeningen zouden worden beslist door twee rechters (o id ores), in tegenwoordigheid van twee "contadores" met raadgevende stem en verplichting tot geheimhouding der beraadslagingen. Het Openbaar Ministerie (Fiscal de la Audiencia) vertegenwoordigde de belangen van het openbaar gezag. Waren de oidores het met elkander niet eens, dan benoemde de landvoogd of de voorzitter der rechtbank een derden rechter. In hoogste ressort kon de beslissing van den Koning worden ingeroepen op de wijze door de wetten van het moederland voorgeschreven. Geen uitspraak mocht worden gedaan voordat voldaan was aan de bevelen van de "Contadores.

De landvoogd en de voorzitter der rechtbank hadden het recht de zittingen der Rekenkamers bij te wonen, ten einde zoo noodig ter zake voorstellen aan den Koning te doen. Omgekeerd had de oudste "Contador de Cuentas» zitting bij de beraadslagingen, die de landvoogd over financieele aangelegenheden belegde, met recht zijn gevoelen te uiten en zijne stem uit te brengen.

De “Contadores" mochten geen belang hebben bij contracten met de Regeering, en geen geschenken aannemen. Bloedof aanverwantschap tot den vierden graad mocht niet bestaan tusschen hen en hunne rekenplichtigen. Zonder verlof van den Koning mochten ook geen huwelijken voltrokken worden tusschen hunne kinderen.

1 Men vergelijke bl. 157. 
Bij ontdekking van valschheden waren de (contadores) bevoegd voorloopige maatregelen te nemen, totdat het Openbaar Ministerie de zaak in behandeling kreeg. De rechterlijke macht en het administratief gezag mochten zich overigens sedert 1618 niet met de zaken der Rekenkamers inlaten. Wanneer voormeld gezag weigerde te voldoen aan verzoeken van de Rekenkamers, hadden dezen hiervan bericht te geven aan den Koning.

De ontvangers, tevens betaal- en magazijnmeesters, voerden den titel van "Oficiales Reales" en waren tot zekerheidstelling verplicht. Hun kantoor werd aangeduid als « Tribunal de $\mathrm{Hacienda}{ }^{1} \mathrm{Real}$. Overigens onderscheidde de wet het personeel in "tesorero", "contador, en "factor". De "factores, hadden in het bijzonder te zorgen voor de administratie van de levensmiddelen, de munitie en ander oorlogsmateriaal. $\mathrm{Zij}$ en de stesoreros, hadden jaarrekeningen over te leggen aan de "contadores». Vroeger waren er ook 'veedores, of "proveedores" (toezichthouders).

De "oficiales Reales" mochten geen gemeente-ambten vervullen en hetzelfde verbod gold voor hunne bloed- en aanverwanten en hunne vrouwen. Ook het zijn van cencomenderos, 2 was verboden. Huwelijken tusschen familieleden van 'oficiales reales, in dezelfde provincie eveneens.

Elke week werd eene financieele bijeenkomst ( $\mathrm{Junta}$ de $\mathrm{Ha}$ cienda) gehouden met de hoogste autoriteiten, ten einde loopende zaken te bespreken en te beslissen. Jaarlijks hadden zij gespecificeerde rekening en verantwoording van hun beheer te doen aan den betrokken 'Tribunal de Cuentas, en aan den Raad van Indië te Sevilla, die bovendien om de drie jaren een overzicht van de afgesloten rekeningen had te ontvangen.

Voor de mijnen berustte de administratie bij aescribanos de registros, voor wie reeds in 1565 eene uitvoerige instructie werd vastgesteld, evenals toen en later voor de "oficiales reales».

Hetzelfde gold voor de landskassen (»cajas reales») n.l. de inrichting daarvan, de bewaring der daarbij behoorende sleutels, en de zorg voor den inhoud, alsmede voor het groot aantal aan te houden boeken ( libros reales») en de boekhouders.

De 'oficiales reales, waren ook belast met de ontvangst

1 Hacienda $=$ Financiën.

Z Zie hoofdstuk XIV. 
van hetgeen uit onderscheiden hoofde door inboorlingen werd opgebracht.

Overstortingen uit de koloniale kassen in de moederlandsche schatkist moesten jaarlijks op voorgeschreven wijze geschieden, behoudens een te goeder rekening toegestaan bedrag voor het doen van uitbetalingen.

De schatkist-bijdragen uit het maederland werden aangeduid met het woord situados. Men vindt hiervan slechts ter loops op enkele plaatsen melding gemaakt zonder verderen uitleg.

Voor de betalingen uit 's lands kas bestonden verschillende voorschriften, welke ook uit geschiedkundig oogpunt niet meer van belang zijn. Hetzelfde geldt van al hetgeen betrekking had op de in te dienen rekeningen.

De Tribunales de Contadores zijn blijven bestaan totdat de koloniën zelfstandigheid verkregen. Voor Cuba en Portorico alsmede voor de Filipijnen en het Spaansch territoir aan de Golf van Guinea, werden bij Koninklijk besluit van 26 October 1888 afzonderlijke afdeelingen (salas) opgericht bij de Algemeene Rekenkamer (Tribunal de Cuentas) te Madrid. Sedert het verlies van de eerstgenoemde drie gebiedsdeelen, heeft voormelde Rekenkamer alleen bemoeienis met het laatste gebied. Het beheer over het Marokkaansche territoir loopt over het Ministerie van Buitenlandsche Zaken (Ministerio de Estado).

\section{Belastingen. ${ }^{1}$}

\section{$\S 1$. Belasting in geld.}

Voor het eerst in 1523 gelastte Karel I (V), dat de inboorlingen als onderdanen van Spanje eene matige bijdrage voor de Staatsuitgaven moesten afstaan, evenals zij dit deden aan hunne vroegere heerschers, en wel van de landelijke opbrengsten. De inning was opgedragen aan de landheeren (encomenderos). Inboorlingen, die tot het christendom waren overgegaan, hadden sedert 1575 gedurende twee jaren slechts de helft te voldoen van hetgeen opgelegd was aan de ongeloovigen. Een gedeelte werd onder afzonderlijk beheer besteed voor den bouw van ziekenhuizen, waar ook de christelijke leer werd onderwezen. Later nog,

1 Men vergelijke voor belastingen en andere opbrengsten ten behoeve van de schatkist: bl. $83,84,92,94,121,123,127,128,129,133,166,168,173$, $174,175,176,178,180$ en 181 . 
in 1607, verkregen de bekeerlingen als voorrecht vrijheid van belastingen in geld of arbeid gedurende tien jaren, terwijl zij in dien tijd ook niet geacht mochten worden te behooren tot een particulier land (encomienda). Zij konden echter wel met eigen toestemming na verloop van vijf jaren op dagloon werken.

De belasting in geld (tributos) bedroeg $\frac{1}{10}$ der inkomsten, verkregen uit oogst, veeteelt, enz. (diezmos). Aanvankelijk geheel ten bate van de kerk, werd sedert $1638 \frac{2}{9}$ daarvan in de schatkist gestort ${ }^{1}$.

\section{\$2. Belasting in arbeid (mita).}

Behalve belasting in geld, bestond ook die in arbeid (mita $=$ heerendienst), welke verricht werd hetzij voor den Staat hetzij voor de en comenderos». ${ }^{2}$ De belastingplichtigheid begon met het $18^{\mathrm{e}}$ en eindigde met het $50^{\mathrm{e}}$ levensjaar (1578). Aanvankelijk was voor het begin vastgesteld het ophouden van het vaderlijk gezag, maar om zich aan de verplichting te onttrekken, bleven velen schijnbaar onder dit gezag, door eerst te huwen nadat de leeftijd van 25 of 30 jaren bereikt was, terwijl vroeger dikwijls reeds op 12 jarigen leeftijd een huwelijk werd aangevangen. De misstanden, welke uit het late huwelijk volgden, gaven aanleiding tot de nieuwere bepaling, waaraan toegevoegd was, dat in de bevolkingsregisters der dorpen de namen en leeftijden der zoons te vermelden viel.

De belastingplicht rustte ook op kinderen van negers, al waren dezen ook slaven. Zoo ook op hen, die in mijnen en andere ondernemingen van Spanjaarden werkten, daar zij meestal 4 tot 5 pesos 's maands verdienden, en dus zonder bezwaar minstens 2 pesos 's jaars konden afdragen (1575). In 1601 en 1626 werd aangedrongen op vermijding van opdrijving.

De van elders aangevoerde mijnwerkers, die tevens een bepaald soort werk verrichtten, werden in 1580 van belasting vrijgesteld, onder toekenning van eene vergoeding aan de encomenderos.

De bazen waren vrijgesteld van heerendienst, doch hadden

1 Sedert 1842 was op Cuba $2 \frac{1}{2} \%$ der netto-opbrengst van de velden verschuldigd. Op de Filipijnén betaalden de inboorlingen $10 \%$ van de oogst (diezmo predial).

3en vergelijke hoofdstukken XVI en XVII. 
in geld bij te dragen aan de schatkist, dan wel onbetaald werk te doen ter beoordeeling van de bestuursambtenaren.

Aan het euvel, dat bij de inning der eenmaal vastgestelde belasting niet gelet werd op de overledenen en naar elders vertrokkenen, werd tegemoetgekomen door de bepaling dat de nog aanwezigen niet noodeloos mochten worden bezwaard.

\section{§3. Requintos en toston.}

In 1591 werd met het oog op den noodtoestand der schatkist, boven de gewone belasting $\frac{1}{5}$ daarvan geheven, niet als belasting, maar als dienstbetoon aan den Koning (no es tas a sino servicio que se nos (den Koning) hace). Deze regeling droeg de namen van requinto (vijfde penning) en toston. ${ }^{1}$ Daarentegen werd in 1614 vrijstelling verleend van hetgeen als tomin ${ }^{1}$ van het inkomen der corregidores werd geind.

Van belasting waren vrijgesteld inlandsche alcaldes (dorpshoofden), de oudsten (caciques) en hunne minderjarige kinderen. Sedert 1618 ook alle vrouwen, zonder onderscheid van leeftijd. Te voren droegen de vrouwen bij door het onbetaald weven van kleedingstukken, dekens en katoenen goederen.

\section{§ 4. Media anata.}

Eene andere belasting was de media anata, in 1631 door Filips IV voor alle deelen van het Rijk ingesteld om tegemoet te komen aan de belangrijke tekorten der schatkist ("con o casión de los grandes empeños en que nuestra Real Hacienda se hallaba»). Zij werd geheven bij de benoeming tot eenig ambt, bij de toekenning van eeretitels en alle andere koninklijke gunstbewijzen - ook bij de verleening van encomiendas - en bedroeg de helft van de wedde of andere inkomsten over het eerste jaar. Van 1642 tot 1649 was het bedrag met $50 \%$ verhoogd. Zelfs de zonen des Konings waren tot betaling verplicht.

De betaling geschiedde in twee deelen. Het eerste dadelijk, voordat de besluiten werden uitgereikt; het tweede in den loop van het jaar. Voor dit deel moest tot tevredenheid van den

1 Toston was de benaming van een vroegere zilveren munt, ook als tomin angeduid. De gehalte bedroeg 6 decigram. 
algemeenen schatmeester, dan wel van den betrokken ontvanger zekerheid worden gesteld, met dien verstande dat de betalingsverplichting verviel ingeval van overlijden tusschentijds.

$\mathrm{Bij}$ verlofsverleening naar het moederland, bedroeg de belasting $\frac{1}{10}, \frac{1}{8}, \frac{1}{4}$ of $\frac{1}{2}$ van het verlofstraktement over een jaar, al naarmate het verlof verleend werd voor 1, 2, 3 of meer jaren.

Ook voor gunstige beschikkingen op verzoekschriften aan den Raad van Indië was de belasting verschuldigd.

De geestelijken ${ }^{1}$ en de militairen van leger en vloot in oorlogstoestand ("sirviendo en guerra viva») waren vrijgesteld.

\section{§5. Alcabala.}

Verder bestond reeds in oude tijden, ook in het moederland, eene heffing als alcabala ${ }^{2}$ aangeduid, verschuldigd van alles - behoudens enkele uitzonderingen - wat op eenigerlei wijze verkregen werd, dan wel van den een op den ander overging. Het bedrag verschilde naar gelang van den aard der verkregen goederen, en bedroeg meestal $2 \%$. Inboorlingen waren vrijgesteld.

\section{§ 6. Oplegging van belastingen krachtens de wet.}

Het opleggen van belastingen, in het bijzonder die op de levensmiddelen (sisas), de verdeeling hiervan (derramas) en de aanslag daarin, mocht reeds sedert 1563 uitsluitend geschieden krachtens de wet. Alleen voor bepaalde doeleinden mochten heffingen van hoogstens 200 gouden pesos krachtens besluit van de Audiencias geschieden. Dit laatste gold echter niet voor de inboorlingen. Slechts voor bruggenbouw mocht $\frac{1}{6} \mathrm{der}$ uitgaven door de betrokken Audiencia te hunnen laste worden gebracht.

Later was $2 \%$ verschuldigd van de jaarlijksche opbrengst der wijngaarden.

$\mathrm{Bij}$ het tot stand brengen van openbare werken, zooals aanleg van wegen, bouwen van bruggen, oprichten van werkplaatsen, had de landvoogd te zorgen voor de begrooting van kosten

1 Blijkbaar in verband met de door de geestelijken opgebrachte mesada eclesiástica (zie hoofdstuk II).

Opmerkelijk is, dat de ook in andere landen, o. a. in Engeland, bestaande annats (van het Latijnsche annus) een kerkelijk karakter droegen. Zie o. a. J. E. Worcester. Diot. of the English language.

2 Van het Arabische woord a-cabâla = toewijzing van een stuk grond of iets anders tegen voldoening van eenig bedrag, aan de schatkist. 
en voor den omslag daarvan over de naast belanghebbenden, met inachtneming van hetgeen voor de bijdragen van inboorlingen is voorgeschreven. Het toezicht hierbij was opgedragen aan een der regidores.

\section{§ 7. Aanslag in de belastingen.}

Voor den aanslag in de belastingen werden in 1536 en later verschillende bepalingen vastgesteld. O.a. moest aan de werkzaamheden voorafgaan een plechtige mis met eedsaflegging. Van den aanslag, waarop belanghebbenden gehoord werden, maakte $\cdot$ men een geschrift op, waarin elks aandeel op duidelijke wijze was aangegeven, met bedreiging van strenge straffen tegen ieder die meer vorderde. Dit meerdere werd dan tevens teruggegeven. Voor dit stuk waaraan ook de encomenderos gebonden waren, kregen de oudsten en den Raad van Indië afschriften.

\section{§ 8. In- en uitvoerrechten.}

In- en uitvoerrechten werden in sommige gevallen geheven, zoowel tusschen het moederland en de onderscheiden koloniën als tusschen deze laatsten; zij waren soms zeer hoog, zelfs $50 \%$, bepaaldelijk dàn, wanneer goederen voor eenig gewest bestemd, ten slotte in een ander werden ingevoerd. Uitvoer van goud en zilver was in enkele gevallen verboden, en eveneens doorvoer in het algemeen.

De uitvoerrechten van goederen naar de koloniën verzonden, bedroegen aanvankelijk $2 \frac{1}{2} \%$, doch werden in 1566 en later verhoogd tot $5 \%$ en tot $10 \%$. Bij invoer in de koloniën was nog eens $5 \%$ verschuldigd, samen $15 \%$. Voor wijn moest alles bijeen $20 \%$ worden opgebracht. De gezamenlijke benaming van deze belasting was almojarifazgo». ${ }^{1}$ De inners werden aangeduid als salmojarifes». Ter voorkoming van bedrog, waren zij verplicht aan elk schip lijsten mede te geven van de ingeladen goederen, van hunne geschatte waarde, en van de daarvoor betaalde rechten. Deze lijsten werden in handen gesteld van de "oficiales reales" in de kolonie van invoer voor de controle bij de lossing.

1 Almorifazgo hangt samen met het Arabische al-mochrif $=$ toezichthouder. De belasting werd reeds door de Mooren geheven van de goederen in de havens van Andalucia ingevoerd. 
Ook van ingevoerde slaven was de "almojarifazgo» op te brengen.

In de Filipijnen was over het algemeen $3 \%$ verschuldigd; bij invoer uit China $6 \%$.

Invoer van boeken was vrijgesteld van rechten.

Betaling was overigens niet verschuldigd voor hetgeen geestelijken en anderen voor zichzelf en hun gezin voor eigen gebruik in de koloniën medevoerden, of terug naar het moederland.

Tot tegengang van ontvreemdingen aan boord der schepen, waren premies uitgeloofd voor de aanbrengers en voor anderen, die bij de noodig blijkende maatregelen diensten bewezen.

\section{§ 9. Regie.}

Regie bestond o. a. van kwikzilver, dat in geen geval van de eene kolonie naar de andere, noch ook naar het moederland mocht worden uitgevoerd, zelfs niet in zeer kleine hoeveelheden, op straffe van verbeurdverklaring en geldboete. Vervoer van kwikzilver van Staatsmijnen mocht alleen in vastgestelde verpakking en hoeveelheid geschieden. De prijs van inlevering aan den Staat was bepaald op 60 dukaten per quintal (een gewicht van 100 pond).

Ook zout was aan regie onderworpen, waar dit zonder schade voor de inboorlingen mogelijk was. En zoo ook peper. Verder speelkaarten en sublimat.

Cochinilla was uitdrukkelijk uitgesloten van de regie.

In verband met de regie wordt ook vermeld het verplicht gebruik van gezegeld papier, waaromtrent in 1638 uitvoerige bepalingen werden gemaakt.

\section{Naschrift.}

Terwijl onze gedachten gingen over de instellingen en voorschriften in de vorige bladzijden vermeld, zagen wij het beeld oprijzen van het onmetelijk groote Rijk onder Spaansche heerschappij tot stand gekomen.

Tevens echter kwam ons voor den geest, hoe dit Rijk uiteengevallen is, niettegenstaande de angstvallige voorzorgen tot behoud daarvan.

Voor een deel zal dit wel toe te schrijven zijn juist aan de dikwijls overdreven voorbehoedmiddelen, omdat hieruit economische en politieke dwalingen voortvloeiden, die ten slotte de buitengewone rijkdommen door land- en mijnbouw, door handel 
en scheepvaart verkregen, voor het moederland deden verloren gaan.

Bovendien leert de geschiedenis ons, dat nog nimmer een groot Rijk is blijven bestaan, wanneer dit zich uitstrekt over meer dan één werelddeel, en uiteenloopende gebiedsdeelen bevat.

Op het tijdperk, toen bijna elk uit Sevilla en Cadix uitzeilend schip tot vergrooting van gebied voerde, volgde een ander, waarin telkens landstreken van het Rijk afvielen.

Toch is het koloniale werk van Spanje hoogst belangrijk in zijne gevolgen.

De zelfstandig geworden landstreken toch gaven blijk van levensvatbaarheid, en deze hadden zij aan het moederland ontleend, welks voorbijgegane macht voor altijd zijn stempel had gedrukt. Dit gold niet alleen de taal en de letterkunde, de kunst en de muziek, maar ook en vooral den godsdienst en de algemeene begrippen, waardoor het eene volk van het andere te onderkennen is.

Spanje is niet in staat gebleken om zijn ver uitgestrekt gebied bijeen te houden, maar wèl is de kracht, die van dit land uitging, zóó groot geweest - en dit verdient zeker nog meer aandacht - om blijvend zijn zieleleven te schenken aan de gebiedsdeelen, die zich meenden te moeten losrukken.

Daardoor zijn dezen, zich verheugende in de verkregen zelfstandigheid, voor het moederland een gevoel van warme aanhankelijkheid blijven koesteren, dat zich in steeds toenemende mate openbaart.

De Amerikaansche republieken zijn als kinderen, die, volwassen geworden, het ouderlijk huis verlaten, maar telkens met welbehagen daarin terugkeeren, om zich te laten koesteren door de herinnering aan het vele goede van vroegere tijden. ${ }^{1}$

Zelfs de Filipijnen, Cuba en Portorico, die bij het einde der vorige eeuw jubelden, toen zij het Spaansche gezag zagen plaats maken voor het Noord-Amerikaansche, blijven aan het eerste getrouw, door naast het Engelsch, de taal van den Cid Campeador te spreken, en in hun wezen den Spaanschen geest levendig te houden.

Dit wijst op het bestaan van een onverbreekbaren band, die

1 Onder het afdrukken kwam mij in handen een merkwaardig boek van I. Goldberg „Studies in Spanish-American Literature" New York Brentano's, en Londen Harrap \& Co., 1919. Het bevat de volgende dichtregels uit de 
Spanje heeft weten te leggen, niettegenstaande de minder juiste opvattingen, die zich in den loop der jaren geopenbaard hadden.

Wij hebben gezien met hoeveel zorg de Spaansche heerschers vervuld waren voor de inheemsche bevolking. Wij beseffen tevens, dat niettemin in vele opzichten deze bevolking geleden zal hebben door de zelfzucht van hen, die zich in de overzeesche gewesten vestigden en niet altijd onder toezicht te houden waren.

$\mathrm{Na}$ te gaan, in hoeverre dit lijden minder zou zijn gevoeld onder eigen machthebbers, is niet meer mogelijk. Een geschiedkundig feit is het echter, dat de onderscheiden rassen in bedoelde gewesten in belangrijke mate in elkander zijn opgegaan, waardoor nieuwe menschengeslachten ontstonden, naast welke de afstammelingen der oorspronkelijke bevolking als zoodanig slechts in beperkte mate bleven voortbestaan.

Het is niet onwaarschijnlijk, dat de familiebanden, die gedurende ruim vier eeuwen ontstonden, veel van het ruwe der eerste ontmoeting zullen hebben doen vergeten.

En zoo kan, ook in dit opzicht, het tegenwoordige Spanje zich verheugen over het in zijn "Ultramar, tot stand gebrachte.

"Epitala mio" van Nervo, een der Zuid-Amerikaansche schrijvers, op 28 April 1906 in den Ateneo te Madrid voor Z. M. don Alfonso XIII voorgedragen:
„Sois rey
Aun en cierto modo, de America, come antes;
Rey, mientras que el idioma divino de Cervantes
Melifique los labios y cante en las canciones
De diez y ocho Repúblicas y cincuenta milliones
De seres; mientras rija las almas y. la mano
El ideal austero del honor castellano."

Gij zijt in zekeren zin nog Koning van Amerika, o Koning, zoolang de goddelijke taal van Cerrantes de lippen streelt en in de liederen zingt van 18 Republieken en 50 millioen menschen; zoolang het hooge ideaal der Kastiliaansche eer de geesten en de hand bestuurt. 